TITLE:

\title{
Studies on the metabolism of pantothenic acid in microorganisms(Dissertation_全文 )
}

$\operatorname{AUTHOR}(\mathrm{S})$ :

Shimizu, Sakayu

CITATION:

Shimizu, Sakayu. Studies on the metabolism of pantothenic acid in microorganisms. 京都大学, 1974, 農学博士

ISSUE DATE:

1974-07-23

URL:

https://doi.org/10.14989/doctor.k1520

RIGHT: 


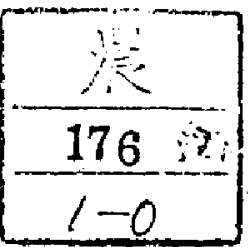

STUDIES ON THE METABOLISM OF

PANTOTHENIC ACID IN MICROORGANISMS

SAKAXU SHIMUZU

\section{果9}




\section{STUDIES ON THE METABOLISM OF}

\section{PANTOTHENIC ACID IN MICROORGANISMS}

SAKAYU SHIMIZU

1974 


\section{CONTENTS}

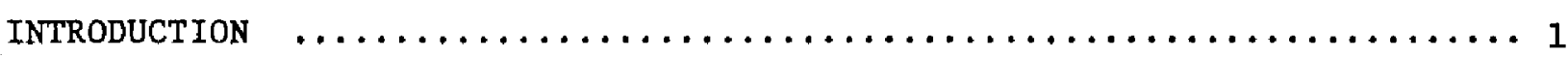

CHAPTER I. SYNTHESIS OF COENZYME A BY MICROORGANISMS $\ldots \ldots \ldots \ldots \ldots \ldots$

Section I. Distribution of Coenzyme A Accumulating Activity In Microorganisms and Isolation of Reaction Products .... 3

Section II. Formation of Coenzyme A by Baker's Yeast $\ldots \ldots \ldots \ldots \ldots \ldots$

Section III. Formation of Coenzyme A by Brevibacterium ammoniagenes

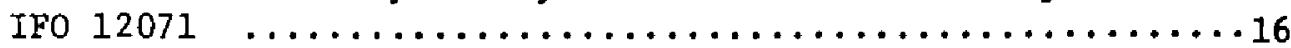

Section IV. An Improved Method for the Fermentative Production of Coenzyme A from Pantothenic Acid, Cysteine, and 5'-AMP $\ldots 22$

Section V. A New Process for the Production of Coenzyme A $\ldots \ldots \ldots \ldots 28$

Section VI. Microbial Synthesis of Intermediates of Coenzyme A

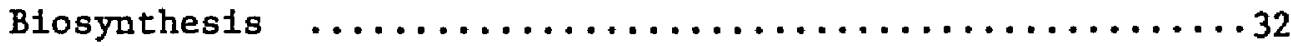

Section VII. Microblal Formations of the Intermediates of Coenzyme A Blosynthesis and thelr Control by Nucleotides .........37

Section VIII. Purffication and Properties of Pantothenate Rinase from Brevibacterium ammoniagenes IFo $12071 \quad \ldots \ldots \ldots \ldots \ldots 4$

Section IX. Some Aspects of the Enzyme Activities Involved in Coenzyme A Blosynthesis in Varlous Microorganisms .......50

CHAPTER II. DEGRADATION OF PANTOTHENYL ALCOHOL BY MICROORGANISMS $\ldots \ldots \ldots 57$

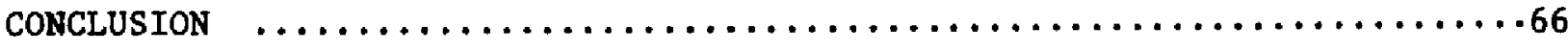

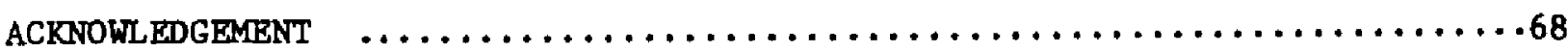

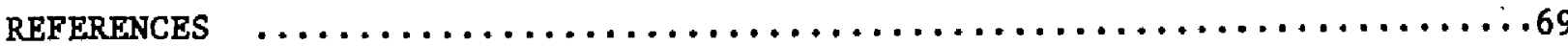


Abbreviations: $C O A$, coenzyme A (COASH and COASSCOA indicate reduced $C O A$ and oxfdized CoA, respectively.); $3^{\prime}$-dephospho-CoA, 3'dephospho-coenzywe A; ATP, adenosine 5'triphosphate; ADP, adenosine $5^{\prime}$-diphosphate; 3',5'-ADP, 3'-phosphoadenosine $5^{\prime}$-monophosphate; AMP, adennsine 5'-monophosphate; GTP, guanosine $5^{\prime}$-triphosphate; GDP, guanosine 5'-diphosphate; GMP, guanosine 5'monophosphate; ITP, Inosine 5'-triphosphate; IMP, Inosine 5'-monophosphate; CTP, cytidine $5^{\prime}$-triphosphate; CDP, cyt1dine 5'-diphosphate; CMP, cytidine $5^{\prime}$-monophosphate; UTP, ur1dine 5'-triphosphate; UDP, uridine 5'diphosphate; UMP, uridine 5'-monophosphate; $N A D$, nicotinamide adenine dinucleotide; NADP, nicotinamide adenine dinucleotide phosphate; FAD, flavin adenine dinucleotide; BDTA, disodium ethylenediamine tetraacetate; DSS, sod 1um 2,2-d 1methy1-2-silapentane-5sulfonate; DRAE-cellulose, diethylaminoethyl cellulose. 


\section{INTRODUCTION}

Ten years elapsed between the time, 1936, that pantothenic acid was first found to participate in carbohydrate metabolism (I) and the time that the mechan 1sm of 1ta function was estab11shed. The realization that pantothentc actd 1tself is not the functional form of the vitamin began with the discoveries that a cofactor was involved in the acetylation of choline in extracts of rabbit brain $(2,3)$ and that of sulfantlamide in pigeon 1tver $(3,4)$, and that this cofactor, named "coenzyme

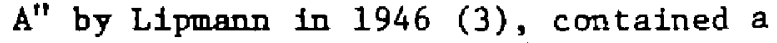
"bound" pantothenlc acid (5). A turning point in the physiological and structural studies on CoA was the discovery by Lynen et aI. $(6,7)$ in 1951 that "active acetate" is an acyl mercaptan. About ten years later, another turning point in the studies relating to CoA was brought from the discovery that 4'-phosphopantethelne, which also contains a "bound" pantothenic acid as well as CoA, functions in fatty acid synthesis as a protein bound prosthetic group ( 8 ). The numerous roles played by these two coenzymes dertved from pantothenic acid in intermediary metabolism have been the subject of intensive research. It has now been evident that CoA is necessary not only for the activation of acetate but also for the activation of many other carboxylic acids and for the transacylation in varlous blological systems, and 4'phosphopantethelne is necessary not only for the elongation of fatty acids but also for the synthesis of peptides (9).

As to the biosynthesis of CoA from pantothenic acid, the first evidence that cysteine serves as the precursor of the sulfur-containing fragment of CoA was supplied by Plerpoint and Hughes (10). They reported that CoA synthesis from pantothenic acid by whole cells of Lactobacillus axabinosus is dependent on the presence of cystelne. This finding was followed by the observation of Brown and Snell (11) that Proteus morganit aloo forms CoA in the presence of cysteine. In 1954, Levintow and Novel11 (12) and Hoagland and Novel11 (13) proposed a pathway for the biosynthesis of CoA in mammalian systems, in which pantothenlc acid couples with cystelne to yleld pantothenoylcyatelne as the first step, followed by decarboxylation to pantetheine, which 18 then phosphorylated to form $4^{\prime}$-phosphopantethelne, and they suggested that the pathway is as follows: pantothenic acid $\rightarrow$ pantothenoylcysteine - pantetheine $-4^{\prime}$-phosphopantetheine $-3^{\text {r}}$ dephosphoCoA $\longrightarrow$ CoA. In 1959, however, Brown (14) proposed an alternative pathipy using rat liver, rat kldney, and Proteus morganii, in which pantothenic acid is first phosphorylated to yleld 4 '-phosphopantothenic acid by the enzyme pantothenate kinase prior to coup1ing with cysteine. 4'-Phosphopantothenic acid is then condensed with cysteine in the presence of an enzyme designated "coupling enzyme" ( $4^{\prime}$-phosphopantothenoylcysteine synthetase) to yield $4^{\circ}-$ phosphopantothenoylcysteine, which in turn is decarboxylated to $4^{\prime}$-phosphopantethelne by the enzyme 4'-phosphopantothenoylcysteine decarboxylase. $4^{\prime}$-Phosphopantetheine is then converted to CoA with ATP by the enzymes $3^{\prime}$-dephospho-CoA pyrophosphorylase and $3^{\prime}-$ dephospho-CoA kinase. The sequence is summarized as follows: pantothenic acid $\longrightarrow 4^{\prime}$-phosphopantothenic acld $\longrightarrow 4^{\prime}-$ phosphopantothenoylcysteine- 4 ' -phosphopantethelne $\longrightarrow 3^{\prime}$-dephospho-CoA $\longrightarrow$ CoA. In these processes 4 moles of ATP are required for one mole of CoA. Brown (14) also suggested that in both mammalian and microbial systems this is the only operative pathway. Later, Ab1ko $(15,16)$ and Ab1ko et al. (17) revalued these two pathways in detail, and confirmed that Brown'a pathway operates in rat liver. However, the pathway envisaged by Novelli may function In one bacterfum, Lactobacillus helveticus. Evidence for this includes (a) pantothenoylcysteine decarboxylase fa present (14); (b) this organism when supplied with large amounts of pantothenic acid will not accumulate $4^{\prime}$ phosphopantothenic acid (18); (c) mutants of Lactobacillus helveticus can 
use pantothenoylcysteine as a growth factor (19). Two other organ1.smb, Lactobacillus buigaricus and Acetobacter suboxydans, which can also utilize pantothenoylcysteine, possibly also follow Novell1's pathway (19).

The flrst h1ghly purifled preparatlong of CoAwere obtained by extracting It from streptomyces fradiae (20), and a series of 1 ts selective enzymatic digestions showed that 1 t contains three equivalents of phosphate and each one equivalent of adenosine and sulfur for each mole of pantothenic actd (21), and can be accounted for as a pyrophosphate ester that Ilnks the adenosine 3'-monophosphate through its $5^{\prime}$-position to the 4'-position of pantetheine (7,2224). During this same perlod, isolatIon procedures for CoA also had been Improved by contributions by Belnert et al. (25) and by Stadtman and Kornberg (26). Befnert et al. (25) obtained highly pure CoA from baker's yeast by coprectpitation with cupper-glutathion. This was later improved by Reece et aI. (27). On the other hand, the structure of CoA established on the basis of degradation data was first confirmed by a total synthesis accomplished by Moffatt and Khorana (28) in 1959. CoA has been supplied only by extraction from microorganisms $(20,21,25-27,29)$ and chemical synthesis $(28,30-32)$. However, these methods are not practical because of their lower yleld or their intricacy. The unsufficient supply of CoA may glve one of the disadvantages in experiments of biochemistry and clinical medicine.

Developments of seasoning manufacture, espectally in Japan, have now permitted easy supply of a variety of nucleosides and nucleotides. By using them, many Investigations on synthesis of more complex nucleotides, such as nucleoside triphosphates, sugar nucleotides, nucleotide coenzymes, and so on, have been done intensively (33). Tochikura et al. (34) have reported an eff1clent synthesis of ATP from adenosine or AMP during the fermentation of yeasts. It is interesting, therefore, to synthesize CoA through the supply of ATP under such fermentative conditions.
The compounds which have a close structural similarity with naturally occurring vitamins are generally known to possess inhlbitory effects on growth of certain organisms or on actiun of certain enzymes. Some of these compounds have proven of interest in biochemical studies and in chemotherapy (35). Pantothenyl alcohol, an alcohol analog corresponding to pantothenic actd, has been reported to be converted by warm-blooded animals into pantothentc acld and to serve as an avallable source of the vitamin for these organisms (36-38), while the analog not only is not utilized in place of the vitamin by lactic acid bacteria, but on the contrary it prevents competitively the utilization of pantothenic acid by these organisms $(39,40)$. However, little is known of the metabolism of this alcohol in other microorgantsms. It seems, therefore, to be interesting to know the microbial response of this antimetabolite.

In this thesis the author describes the microblal metabolism of pantothenic acid and 1 ts related compounds. In the first chapter, searching the abllity of the formation of CoA from pantothenic acid and cysteine under the coupling with ATP-generating system of varlous microorganisms, and accumulation of CoA and its biosynthetic intermediates, then on the basis of the results of these investigations a new process for the production of CoA are described. The mechantsm of the accumulation of these compounds is also discussed. In the second chapter, some aspects of degradation metabolism of pantothenyl alcohol are briefly described. 


\title{
GHAPTER I. \\ SYNTHESIS OF COENZYME A BY MICROORGANISMS
}

\author{
Section I. \\ Distribution of Coenzyme A Acaumulating Activity in Microorganisms \\ and Isolation of Reaction Products $\left.{ }^{2, b}\right)$
}

\begin{abstract}
The ability of the formation of COA from pantothenfc acid and cysteine in the presence of AMP or ATP was searched in yeasts and bacteria. The result of screening showed that the activity was found In several yeasts and bacterla belonging to the genera Sarcina, Corynebacterium, and Brevibacterium. Partlcularly, Brevibacterium ammoniagenes IFO 12071 accumulated a large amount of CoA. Isolation of the reaction products, which were syathesized by Brevibacterium ammoniagenes IFO 12071, were carried out. The isolates were 1dentified as CoA, $3^{\prime}$-dephospho-CoA, and $4^{\prime}$-phosphopantothenic acid.
\end{abstract}

\section{INTRODUCTION}

The numerous roles that CoA plays in Intermediary metaboligm have been discussed by many investigators, since the discovery of this compound as a requirement for acetylation of choline and aromatic amines by Lipmann (3) in 1946.

CoA has been prepared by extraction from microorgan 1sms $(20,21,25-27,29)$ and chemical syathesis $(28,30-32)$. However, these methods are not avallable because of their lower yield or their intricacy.

Although studies on the blological conversion of blosynthetic precursors lncluding pantothenic actd into CoA have been reported in vivo and in vitro (41), 1ittle is known of accumulation of $\operatorname{CoA}$ by microbial process. Only it was reported that a relatively large amount of CoA was syntheslzed by the washed cell suspension of Lactobacilius arabimosus which was grown in pantothenate-deflclent medium (10). As demonstrated by Brown (14), four moles of ATP are required during the synthesis of one mole of CoA from pantothenic ac1d. Tochtlars et al. (34) have reported that adenosine or AMP is phosphorylated to ATP under the fermentatIon process of yeast in the presence of a high concentration of Inorganic phosphorus. It is interesting, therefore, to synthesize CoA through the supply of ATP under such fermentative conditions. In this section, the result of screening of CoA accumulation by various microorganisms and 1solation of CoA and its related compounds are described.

\section{MATERIALS AND METHODS}

Microorganisms and cultivations. Baker's yeast was obtalned from Oriental Yeast Co., Ltd., Tokyo. Other mieroorganisms used were the strains preserved in the Laboratory of Applied Microbiology, Department of Agricultural Chenlatry, Ryoto University. Yeasts were grown in a medium containIng $5 \mathrm{~g}$ of glucose, $0.5 \mathrm{~g}$ of peptone, $0.1 \mathrm{~g}$ of yeast extract, $0.2 \mathrm{~g}$ of $\mathrm{KH}_{2} \mathrm{PO}_{4}$, $0 . \mathrm{I}^{\circ} \mathrm{g}$ of $\mathrm{K}_{2} \mathrm{HPO}_{4}$, and $0.02 \mathrm{~g}$ of $\mathrm{MgSO}_{4}$. $7 \mathrm{H}_{2} \mathrm{O}$ in $100 \mathrm{ml}$ of tap water, $\mathrm{pH} 6.5$. Bacteria were grown in a medium containIng $1 \mathrm{~g}$ of glucose, $1.5 \mathrm{~g}$ of peptone, $0.3 \mathrm{~g}$ of $\mathrm{K}_{2} \mathrm{HPO}_{4}, 0.2 \mathrm{~g}$ of $\mathrm{NaCl}$, and $0.02 \mathrm{~g}$ of $\mathrm{KgSO}_{4} \cdot 7 \mathrm{H}_{2} \mathrm{O}$ in $100 \mathrm{ml}$ of tap water, pH 7.0. Each culture was carried out with $500 \mathrm{ml}$ medium placed in 2 11ter shaking flask under reclprocal shaking at $28^{\circ} \mathrm{C}$ for $2-4$ days. 
Preparation of dried cells. The cella harvested by centrifugation were waged wth $0.857 \mathrm{KaCl}$. The paste of the celle was dried with an electric fan at room temperature, and then put in a desiccator over $\mathrm{P}_{2} \mathrm{O}_{5}$ in vacuo at $4^{\circ} \mathrm{C}$. The dried cells were stored at $-15^{\circ} \mathrm{C}$ before used.

Chemicals. CoA was kindly provided by Dr. E. Ohmura, Takeda Chemical Industrles Co., Ltd., Osaks, and also obtained from SIgma Chemical Co., St. Louls. $3^{\prime}$-Dephospho-CoA and $4^{\prime}$-phosphopantothenlc acld were kindly gifted by Dr. M. Shtmizu, Daflch1 Selyaka Co., Ltd., Tokgo. ATP was kindly gifted by Dr. R. Tanaka, Kyowa Hakko Kogyo Co., Ltd., Tokyo. DEAE-cellulose $(0.9 \mathrm{meq} / \mathrm{g})$ was provided from Green Cross Corporation, Osaka. Phosphotransacetylase of clostridium kluyveri was purchased from Boehringer, Mannhelm. Phosphodiesterase of Crotalus adamanteus and alkaline phosphatase from calf intestinal mucosa were from SIgtra Cheolcal Co., St. Louls. Acetylphosphate was synthesized accordIng to the method of Avison (42). All other reagents were commerclal products of analytical grade of purity.

screening method. For the screening of CoA accumulation, the following standard condtition was used: The reactIon mixture which contained 10 umoles of sodium pantothenate, $10 \mu$ moles of

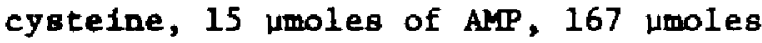
of glucose, $200 \mu$ moles of potassium phosphate buffer, $\mathrm{pH} 7.0$, and $100 \mathrm{mg}$ of dried cells was incubated at $37^{\circ} \mathrm{C}$ in a total volume of $1 \mathrm{ml}$. For the reaction In becterial system, equimolar amounts of ATP were also added instead of AMP. For the screening of pantothenate klnase activity in bacterlal cell system, the following condftion was used: The reaction mixture containing, in $1 \mathrm{ml}, 2$ umoles of sodium pantothenate, 10 moles of ATP, 150 umoles of potassium phosphate buffer, $\mathrm{pH} 6.0,10 \mu$ moles of $\mathrm{MgSO}_{4}$, and $100 \mathrm{mg}$ of dried cells was Incubated at $37^{\circ} \mathrm{C}$ for $2 \mathrm{hr}$. The reactlons were stopped by Immersing the tubes in bollIng water for $5 \mathrm{~min}$. The products were assayed after the removal of cells by centrifugation.
Analytical methods. CoA as8ays vere malaly performed by the phosphotransacetylase method of Stadtman et al. (43) uaing the enzyme of Escherichia coli Crookes ARU 0001 and also by the method of Bergmeyer et al. (44) for characterization of lsolated products. Pantothenic acld was measured microblologlcally using Lactobacillus plantarum ATCC 8014 (45) and Saccharomyces carlsbergensis ATCC 9080 (46) as test organ1sms. Bound pantothenates were assayed by the method of Novel11 (47). Adentne content was determined by ultraviolet absorption in $0.1 \mathrm{M} \mathrm{HCl}$ using $\mathrm{E}_{260}=$ 15,000 as a standard value. Phosphorus was measured by the method of FiskeSubbarow (48), and sulfhydryl by the method of Ellman (49). Paper chromatography by the ascending technique was performed on Toyo Rosh1 No.53 paper using the following solvents: solvent $I$, isobutyric acid-0.5 N ammonium hydroxide-0.1 M EDTA (100:60:1.6, by vol.); solvent $I I$, ethanol-1 $\mathrm{M}$ ammonium acetate, $\mathrm{pH} 7.5(5: 2$, by vol.); solvent III, ethanol-0.5 M ammonium acetate buffer, pH 3.8 (5:2, by vol.); solvent IV, $n-$ butanol-acetic acld-water $(5: 2: 3$, by vol.); solvent $V, n$-propanol-287 ammonfum hydroxide-water ( $6: 3: 1$, by vol.). Paper electrophoresis was performed on Toyo Rosht No. 53 paper Impregnated with $0.05 \mathrm{M}$ sodium acetate buffer, pH 5.1, at $40 \mathrm{~mA}$ per $15 \mathrm{~cm}(4 \mathrm{KV})$ for $30 \mathrm{~min}$. Adenine dertvatives were located on the chromatogram with a UV-lamp. Pantothenic acid and its phosphorylated compound were detected by bloautographic techniques. Phosphorus-containing compound 8 were located with Hanes and Isherwood spray (50) followed by ultravlolet trradiation, and sulfhydryl or disulfide compounds wth Toennles and Kolb spray (51). B-Alanine was detected by ninhydrin apray.

Preparation of phosphotransacetylase from Escherichia coli Crookes AKU 0001. The washed cells ( $12 \mathrm{~g}$, dry welght) were suspended in $100 \mathrm{ml}$ of $0.1 \mathrm{M}$ Tris-BC1 buffer, $\mathrm{pH} 7.4$, and treated wth a Ka1jo-Denk1 $19 \mathrm{kHz}$ ultrasonic oscillator for $10 \mathrm{~min}$. The intact cells and debris were removed by centrifugation 
at $12,000 \mathrm{xg}$ for $20 \mathrm{~min}$. To the supernatant, solid ammontum sulfate was added to give 30 to $40 \%$ saturation. The precipitated protein was collected by centrifugation at $12,000 \times g$ for $20 \mathrm{~min}$ and was dissolved in $10 \mathrm{ml}$ of the same buffer contalning $10 \mathrm{mg}$ of reduced glutathione and $10 \mathrm{mg}$ of bovine serum albumin. All the operations were carried out below $4^{\circ} \mathrm{C}$. This protein solution was used as the phosphotransacetylase preparation.

\section{RESULTS}

Distribution of CoA-accumulating activity in microorganisms

As shown in Table I, the activity of the accumulation of CoA from pantothenlc ac1d, cystelne, and AMP was found in some strains of yeasts, e.g. baker's yeast, Saccharomyces sake AKU
4022, Saccharomyces lactis IFO 1090, beer yeast ARO 4037, Torulopsis candida IFO 0768, Schizosaccharomyces Iiquefaciens IFO 0358, and so on. Under the conditions employed, all of them showed strong AMP-phosphorylating activity. However, inspite of their strong activity to phosphorylate AMP, some yeasts, such as hansenula beijerinckii IFo 0981, Candida utilis IFO 0396, and Brettanomyces claussenii IFO 0627, did not show the accumulation of CoA. It was also observed that yeasts degrading AMP to adenosine, inosine, adentne, or hypoxanthine did not show the accumulation of CoA. While, nelther consumption of pantothenic acid nor accumulation of CoA was observed in a simtlar reaction system with bacteria. When ATP was added to the reaction mixture in place of AMP, the consumption of pantothenic acid in the reaction mixture was obser-

TABLE I. ACCUMULATION OF COA BY YEASTS

The reactions were carried out for $5 \mathrm{hr}(* 3 \mathrm{hr})$ under the conditions as described in the text.

\begin{tabular}{|c|c|c|c|}
\hline before & $\begin{array}{l}\text { CoA found }(\mu \mathrm{g} / \mathrm{m} \\
\text { reaction after }\end{array}$ & $\begin{array}{l}\text { 1) } \\
\text { reaction }\end{array}$ & $\begin{array}{c}\text { Metabolites } \\
\text { of AMP }\end{array}$ \\
\hline Bake ${ }^{\top} \mathrm{g}$ yeast & 23 & 128 & ATP, ADP \\
\hline Distillery yeast M AKU 4006 & 45 & 73 & $"$ \\
\hline Beer yeast AKU 4037 & 58 & $100 *$ & $"$ \\
\hline Schizosaccharcmyces I iquefaciens. IFo 0358 & 30 & 80 & $"$ \\
\hline Saccharomyces sake kyokai No. 2 & 31 & 65 & " \\
\hline " AKU 4017 & 68 & $86 \star$ & $"$ \\
\hline$=\quad * \quad$ AKU 4022 & 43 & $85 \star$ & $"$ \\
\hline lact is IFO 1090 & 33 & 75 & $"$ \\
\hline rosei IFO 0252 & 39 & 20 & $"$ \\
\hline - chevalieri IFO 0210 & 64 & 56 & " \\
\hline - Carlsberaensis IFO 0461 & 15 & 6 & adenosine \\
\hline Candida mycoderma IFO 0164 & 26 & $64 *$ & ATP, ADP \\
\hline - utilis IFO 0396 & 15 & 22 & ir \\
\hline Torulopsis candida IFO 0768 & 28 & 77 & $"$ \\
\hline sake IFO 0435 & 18 & 75 & $"$ \\
\hline - globosa IFO 0953 & 51 & 26 & " \\
\hline Hansenula jadinii Ifo 0987 & 24 & 16 & $"$ \\
\hline " beijerinkii Ifo 0981 & 15 & 22 & $"$ \\
\hline " matritensis IFO 0945 & 34 & 21 & hypoxanthine \\
\hline - anomala AKU 4300 & 39 & 43 & "1 \\
\hline Rhodotorula rubra IFO 0890 & 42 & $28 *$ & entne, adenosine \\
\hline m marina IFo 0879 & 30 & 3 & $"$ \\
\hline Brettanamyces claussenii Ifo 0627 & 41 & 16 & ATP, ADP \\
\hline Saccharomycodes ludwigit IFO 1043 & 57 & 13 & AMP \\
\hline Lipomyces starkeyi IFO 0678 & 0 & 6 & $"$ \\
\hline Trigonopsis variabilis IFO 0671 & 37 & 31 & $"$ \\
\hline Schanniomyces accideritalis IFO 0371 & 30 & 6 & adenine \\
\hline Debarianyces subglobosus IFn 0794 & 17 & $22 \star$ & adenosine \\
\hline Kloekera africana IFO 0633 & 30 & 33 * & " \\
\hline
\end{tabular}


TABLE II. ACCUMULATION OF COA BY BACTERLA

The reactiong for CoA formation were carried out for 6 hr under the condtions as described in the text. The wixture omitting sodium pantothenate and cystelne was used as a control run. The values of each control run are given in parentheses. Assay condition for pantothenate kinase activity is given in the text, and the values obtained are given as per cent of pantothenic acid consumed. The mixture onicting ATP was used as a control run. The values of each control run are given in parentheses.

\begin{tabular}{|c|c|c|c|c|c|c|}
\hline \multirow{3}{*}{$\begin{array}{ll}\text { Strain } & \\
\begin{array}{l}\text { Escherichia coli B AKU } 0012 \\
\text { freundij S-96 AKU } 0009\end{array}\end{array}$} & \multicolumn{3}{|c|}{$\begin{array}{l}\text { CoA found } \frac{(\mu \mathrm{g} / \mathrm{ml})}{\text { after }} \\
\text { before }\end{array}$} & \multicolumn{2}{|c|}{$\begin{array}{c}\text { Pancothenate } \\
\text { kinase act Ivity }\end{array}$} & $\begin{array}{c}\text { Metabolites } \\
\text { of ATP }\end{array}$ \\
\hline & 21 & 11 & (5) & 0 & $(0)$ & AMP, adenine \\
\hline & 30 & 18 & -a) & 0 & (0) & adenine \\
\hline Aerobacter aerogenes IFo 3320 & 48 & 18 & (37) & 20 & $(0)$ & AMP \\
\hline Erwinia aroideae IFO 3830 & 63 & 45 & (53) & 20 & $(0)$ & AMP, adenosine \\
\hline Serratia marcescens IFO 3046 & 66 & 58 & (44) & 15 & $(0)$ & AMP \\
\hline Proteus morgandi IFo 3838 & 12 & 18 & (12) & 0 & (0) & AMP, adenosille \\
\hline Alcaligenes faecal is LAM $B-141-1$ & 45 & 91 & (91) & 0 & $(0)$ & AMP \\
\hline Achromobacter aceris IFO 3166 & 30 & 17 & - & 0 & (0) & - \\
\hline Flavobacterium fuscum AKU 0140 & 14 & 15 & (12) & 0 & (0) & hypoxanthine \\
\hline Bacillus subtilis Ifo 3007 & 30 & 25 & - & 0 & (0) & AMP, adenasine \\
\hline Agrobacterium tumefaciens IAM B-26-1 & 25 & 23 & $(24)$ & 0 & $(0)$ & adenine \\
\hline Microcaccus luteus IFo 3763 & 40 & 57 & $(25)$ & 15 & (5) & AMP \\
\hline " sp. No. 431 AKU 0511 & 56 & 70 & $(81)$ & 0 & $(0)$ & hypoxanthine \\
\hline Staphylococcus aureus IFO 3060 & 25 & 26 & - & - & - & - \\
\hline Sarcina aurantiaca IFO 3064 & 58 & 98 & $(35)$ & 55 & $(10)$ & $A M ?$ \\
\hline " lutea IFO 1099 & 68 & 171 & $(67)$ & 75 & $(15)$ & $"$ \\
\hline I I FO 3232 & 64 & 181 & $(67)$ & 70 & (5) & 4 \\
\hline - variabilis IFO 3067 & 72 & 89 & (97) & 65 & (5) & $A M P, A D P, A T P$ \\
\hline Corynebacterium glutamicum ATCC 13032 & $6 i$ & 53 & $(62)$ & 80 & $(25)$ & AMP, ADP \\
\hline$" \quad$ ATCC 13059 & 60 & 101 & (51) & 80 & (5) & AMP \\
\hline$* \quad$ ATCC 13060 & 42 & 109 & $(40)$ & $7 n$ & $(20)$ & $"$ \\
\hline - egui IAM 1038 & 50 & 60 & $(61)$ & 25 & $(10)$ & $"$ \\
\hline Arthrobacter simplex Ifo 3530 & 39 & 60 & - & 40 & $(0)$ & $"$ \\
\hline Brevibacterium divaricatum 1627 NRRL 2311 & 123 & 98 & $(85)$ & 70 & (5) & AMP, ADP \\
\hline " ammoniagenes IFO 12071 & 19 & 830 & (0) & 100 & (5) & $"$ \\
\hline IFO 12072 & 16 & 289 & $(33)$ & 85 & $(10)$ & $"$ \\
\hline sp. P145 AKU 0643 & 125 & 115 & $(122)$ & 0 & (5) & $"$ \\
\hline sp. AKU 0644 & 109 & 114 & $(107)$ & 60 & (5) & $"$ \\
\hline 9P. AKU 0645 & 90 & 124 & $(87)$ & 60 & $(0)$ & " \\
\hline Bacterium cadaveris IFO 3731 & 62 & 18 & (12) & 0 & (0) & hypoxanthine \\
\hline Pseudamonas fluorescens IFO 3461 & 55 & 44 & $(35)$ & 0 & (5) & AMP \\
\hline
\end{tabular}

a) not tested.

ved by several strains belonging to the genera Sarcina, Corynebacterium, and Brevibacterium (Table II). Among them Brevibacterium ammoniagenes IFO 12071 showed a remarkable accumulation of CoA. A typical time course for CoA synthesis by Brevibacterium ammoniagenes IFO 12071 Is shown in FIg. 1. The amounts of CoA synthesized from pantothenic acid and from pantethine after $8 \mathrm{hr}$ incubation reached about 1.3 umoles ( $1.0 \mathrm{mg}$ ) per ml and 1.7 umoles ( $1.3 \mathrm{mg}$ ) per ml, respectively. The omission of these pantothenate derivatives from the reaction mixture gave no accumulation of CoA. An addition of sodium laurylbenzenesulfonate brought an increase of the amount of CoA synthesized. When cysteine was omitted from the reaction mixture, more than $95 \%$ of pantothenlc acid added disappeared after 8 hr incubation without the accumulation of CoA. The disappearance of pantothenic acld was completely recovered by the treatment with alkaline phosphatase, suggesting the presence of confugated forms of pantothenic acid in the reaction mixture. 


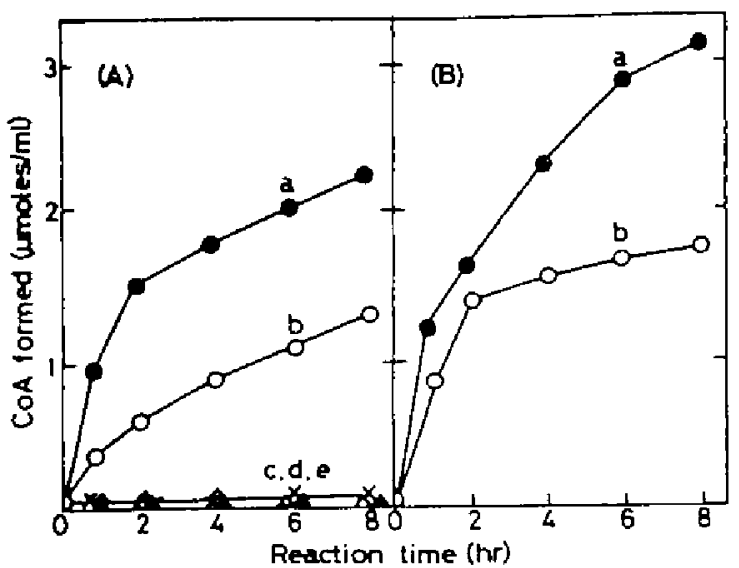

FIG. 1. Time Course for CoA Synthesis.

(A) Synthesis from pantothenic acld: The reaction mixture contalning, in $1 \mathrm{ml}, 5$ moles of sodium pantothenste, 10 wooles of cysteine, 15 umoles of ATP, 10 imoles of $\mathrm{MgSO}_{4}, 150$ umoles of potassium phosphate buffer, $\mathrm{pH} 6.0$, and $100 \mathrm{mg}$ of dried cells of Brevibacterium amoniagenes IFo 12071 was incubated at $37^{\circ} \mathrm{C}$ wth (a) or wthout (b) 2 gi of godium laurylbenzenesulfonate. The mixture without sodfum pantothenste (c) or cystelue (d and e) was used as a control run. (The mixture (e) contalned 2 of ordium laurylbenzenesulfonate.)

(B) Synthesis from pantethine: The reaction conditions were the same as those in (A) except for 2.5 woles of pantethine replacing sodium pantothenate.

\section{Isolation and characterization of the reaction products}

Isolation of the reaction products. The reaction mixture containing 3 moles of sodium pantothenate, 6 moles of cystelne, 6 moles of ATP, 3 mmoles of $\mathrm{MgSO}_{4}, 45$ moles of potasstum phosphate buffer, $\mathrm{pH} 6.0,600 \mathrm{mg}$ of sodium laurylbenzenesulfonate, and $30 \mathrm{~g}$ of drted cells of Brevibacterium ammoniagenes IFO 12071 in a total volume of $300 \mathrm{~m} 1$ was Incubated for $10 \mathrm{hr}$ at $37^{\circ} \mathrm{C}$. Then, the mixture was 1 mersed for $10 \mathrm{~m} 1 \mathrm{n}$ in a bolling water and cells were removed by centrifugation. The supernatant was placed onto an active charcoal colum $(5.5 \times 10 \mathrm{~cm})$ after adjusting to $\mathrm{pH} 3.0$ with diluted HCl. The column was washed with water and the adsorbed materials vere eluted with ethanol-ammontum hydroxide-water $(50: 5: 45$, by vol.). The eluate was concentrated to about $100 \mathrm{ml}$ under reduced pressure below $35^{\circ} \mathrm{C}$.
After adjusting to $\mathrm{pH} 7.0$ with ammonium hydroxide, $25 \mathrm{ml}$ of 2-mercaptoethanol were added to the concentrate and the mixture was left overnight at $7^{\circ} \mathrm{C}$, after which 1 t was applied to a coluan of DEAE-celiulose. The elution was carried out as shown in Fig. 2. Each

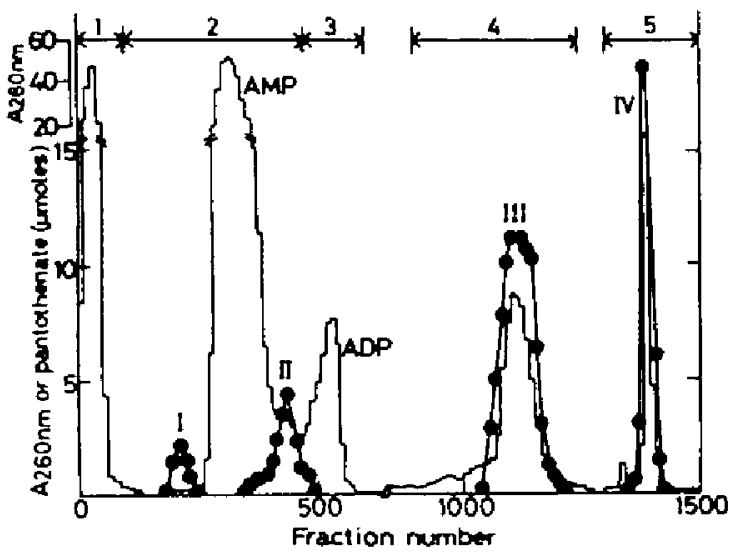

FIG. 2. A Typical Elution Pattern of the Reaction Products from a DEAE-cellulose Colum.

Products were eluted from the colum (chroride form, $5.5 \times 36 \mathrm{~cm}$ ) with $0.003 \mathrm{M} \mathrm{HCl} \mathrm{(1).}$ $0.016 \mathrm{M} \mathrm{LiCl}$ 1n $0.003 \mathrm{M} \mathrm{HCl}$ (2), $0.02 \mathrm{M} \mathrm{LACl}$ in $0.003 \mathrm{M} \mathrm{HCl}$ (3), $0.05 \mathrm{M} \mathrm{LACl}$ in $0.003 \mathrm{M} \mathrm{HCl}$ (4), and $0.2 \mathrm{ML} L \mathrm{Cl}$ in $0.003 \mathrm{M} \mathrm{HCl} \mathrm{(5).} \mathrm{Each}$ fraction contains $18 \mathrm{ml}$ of eluate. Peak $I$, free pantothenic acid; Peak III, CoASH; Peak IV, COASSCOA: Peak II contains mainly $4^{\prime \prime}-$ phosphopantothenic acid and $3^{\prime}$-dephospho-CoA. - absorbance at $260 \mathrm{~nm} ;-$, pantothenate.

pantothenate-containing peak was pooled, adjusted to $\mathrm{pH} 4.5$ with diluted LIOH, and evaporated under reduced pressure below $35^{\circ} \mathrm{C}$. To the residue, a small volume of methanol and 20 volumes of acetone were added to give a white powder. After removing LICl by repeated extractions with methanol-acetone ( $1: 15$, by vol.), it was dried over $\mathrm{P}_{2} \mathrm{O}_{5}$ in vacuo to yleld the Itthim salts of pantothenate-containing compounds.

Characterization of the isolates. i) COASH. The isolated sample (Peak III), $391 \mathrm{mg}$, was well Identical with authentic CoASH in high voltage paper electrophoresis and paper chromatography (Table III). It gave pantothenic acid by the procedure of Nove111 (47), and $3^{\prime}, 5^{\prime}-A D P$ and a sulfhydryl compound 
TABLE III. PAPER CHROMATOGRAPEY AND PAPER ELECTROPHORESIS

\begin{tabular}{|c|c|c|c|c|c|c|c|}
\hline \multirow{2}{*}{ Compound } & \multicolumn{5}{|c|}{ Rf in solvent } & \multicolumn{2}{|c|}{ Mob111ty } \\
\hline & I & II & III & IV & $\mathbf{v}$ & A & B \\
\hline \multicolumn{8}{|l|}{ COASB } \\
\hline authentic & 0.57 & 0.15 & 0.32 & 024 & -b) & 15.4 & 14.5 \\
\hline 1solated & 0.57 & 0.15 & 0.31 & 0.24 & - & 154 & - \\
\hline \multicolumn{8}{|l|}{ COASSCOA } \\
\hline authentic & 0.40 & 0.01 & 0.10 & - & - & 17.1 & - \\
\hline tsolaced & 0.39 & 0.01 & 0.11 & - & - & 17.1 & - \\
\hline \multicolumn{8}{|l|}{$\mathrm{DP}-\mathrm{COASH}$} \\
\hline $\begin{array}{l}\text { autheatic } \\
\text { isolated }\end{array}$ & 0.69 & 041 & 0.42 & - & - & 10.7 & - \\
\hline $\begin{array}{l}\text { isolated } \\
\text { P-PaA }\end{array}$ & 0.69 & 041 & 0.40 & - & - & 10.7 & - \\
\hline \multicolumn{8}{|l|}{$\mathrm{P}-\mathrm{PaA}$} \\
\hline $\begin{array}{l}\text { authentic } \\
\text { isolated }\end{array}$ & $\begin{array}{l}0.53 \\
0.53\end{array}$ & - & - & $\begin{array}{l}0.59 \\
0.59\end{array}$ & $\begin{array}{l}0.33 \\
0.34\end{array}$ & - & $\begin{array}{l}16.4 \\
16.5\end{array}$ \\
\hline ART & 0.56 & 0.13 & 0.29 & 0.28 & 0.21 & 104 & 8.4 \\
\hline ADP & 0.45 & 0.03 & 0.20 & 0.19 & 0.19 & - & - \\
\hline $3^{\prime}, 5^{\prime}-A D P$ & 0.44 & 0.03 & 0.19 & - & - & - & - \\
\hline ATP & 0.37 & 0.02 & 0.15 & 0.13 & 0.15 & - & - \\
\hline $\mathrm{PaA}$ & 0.73 & - & - & 0.79 & 0.83 & - & 9.5 \\
\hline Pantethine & 0.84 & - & - & 0.83 & 0.85 & - & - \\
\hline Cystelne & 0.60 & - & - & 048 & 0.48 & - & - \\
\hline B-Alanine & 0.63 & - & - & 0.50 & 0.61 & - & - \\
\hline
\end{tabular}

a) Migration towards the anode is given in $\mathrm{cm}$. b) not examined.

Abbreviatlons used: DP-COASH, 3'-dephosphoCoASH; P-PaA, 4'-phosphopantothenic acid; PaA, pantothenic acid.

(Rf, 0.65 in solvent I) by hydrolysis w1th Crotalus adamanteus phosphodlesterase. The latter substance is presumably $4^{\prime}$-phosphopantethelne. The purity was calculated to be $87 \%$ by the method of Bergmeyer et al. (44). The ultraviolet absorption spectrum was characteristic of an adenine-containing compound (UV $\lambda \max$ in $0.1 \mathrm{M} \mathrm{HCl}, 259 \mathrm{~nm}$; UV. $\lambda \max$ in $0.1 \mathrm{M} \mathrm{NaOH}, 260 \mathrm{~nm}$ ). IR spectrum was as follows: IR vmax in $\mathrm{KBr}$ pellet, $723,800,825,870,955,1085,1125,1245$, $1335,1371,1424,1480,1550,1655,1697,2970$, $3330 \mathrm{~cm}^{-1}$. Elementa1 analysis showed $\mathrm{C}, 27.04 ; \mathrm{B}, 5.05 ; \mathrm{N}, 10.427 . \mathrm{C}_{21} \mathrm{H}_{33} \mathrm{O}_{16} \mathrm{~N}_{7}-$ $\mathrm{P}_{3} \mathrm{SLI}_{3} \cdot 8 \mathrm{H}_{2} \mathrm{O}$ requires $\mathrm{C}, 27.13 ; \mathrm{H}, 5.37$; $\mathrm{N}, 10.54 \%$. Ratio of adenosine : pantothentc acld : sulfhydryl : phosphorus, $1: 0.92: 0.92: 2.94$; requlred, $1: 1: 1: 3$. 11) CoAsscoA. The yleld of Peak IV was $153 \mathrm{mg}$. The purfty was calculated to be 897 from the pantothenate content. The loolate showed no activity to phosphotransacetylase of clostridium kluyveri (F1g. 3). Ratio of adenosine : pantothentc ac1d: phosphorus was 1:0.92

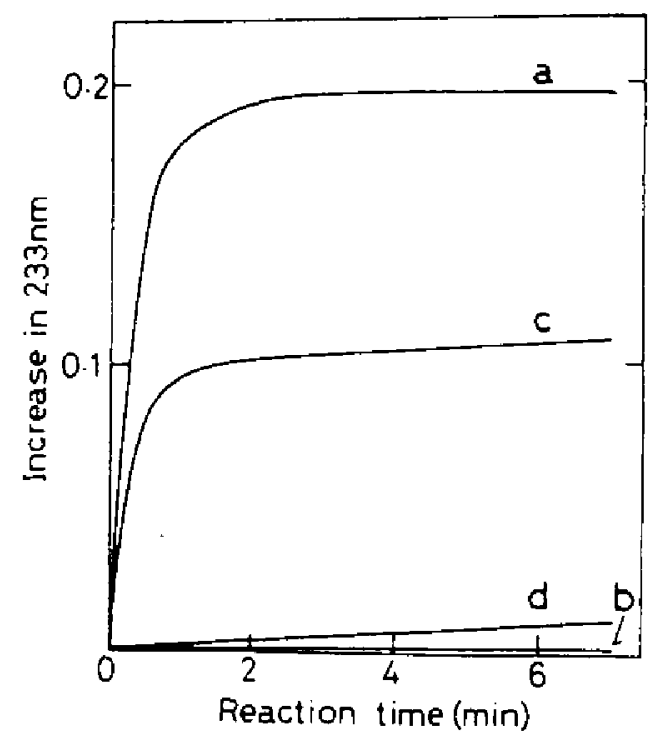

FIG. 3. Acetyl CoA Formation by Phosphotransacetylase.

Each 1 con cuvetce contained 260 umoles of Tris-HCl buffer, $\mathrm{pH} 7.4,26$ umoles of acetyl phosphate, 30 umoles of $\left(\mathrm{NH}_{4}\right)_{2} \mathrm{SO}_{4}$, and 3.3 ug of the enzyme (100 units/mg) in a total volume of $3 \mathrm{ml}$ with 0.13 umole of the isolated COASH (a); 0.13 umole of the isolated CoASSCOA (b) : both 0.07 umole of the isolated COASH and the isolated $3^{*}$-dephospho-CoASH (c): or 0.6 wmole of the isolated $3^{\prime}$-dephospho-CoASH (d).

$: 2.88$; reqiured, $1: 1: 3$. However, after the reduction with 2-mercaptoethanol, it was shown chromatographically to contain reduced $C O A$ and a little of the disulfide. Assayed the reduced sample by the method of Bergmeyer et al. (44), It now showed $83 \%$ activity. Ratio of adenosine : pantothenic acid : sulfhydryl : phosphorus was 1:0.94:0.86:2.91; required, $1: 1: 1: 3$. Other characteristics are shown in Table III.

iii) 4'-Phosphopantothenic acid and 3'dephospho-CoAsH. Peak II was further purifled by DEAE-cellulose column chromatography using a 2 11ter linear salt gradient $(0-0.05 \mathrm{M} \mathrm{LiCl}$ in $0.003 \mathrm{M} \mathrm{HCl}$; colum size, $2.6 \times 65 \mathrm{~cm}$; flow rate, $1 \mathrm{ml} / \mathrm{mln}$ ). Two major pantothenate-contalning peaks were separated. The first eluate (after AMP) was worked up as described above to give a white powder. It contalned phosphorus and neither sulfhydryl nor disulfide. Behaviors on paper chromatography and paper electro- 
phoresis were almost identical with synthettc $\dot{4}^{\prime}$-phosphopantothenic acid (Table III). This compound supported, partially, the growth of Lactobacillus plantarum ATCC 8014 and that of Saccharomyces carlsbergensis ATCC 9080. Free pantothentc acid was 1 iberated from the isolate by the hydrolysis with alkaline phosphatase. From these results, the 1solate was 1dentfied as 4 '-phosphopantothenic acid. The yield was $135 \mathrm{mg}$. The purity based on pantothenlc acid was $62 \%$. Another eluate was obtained as a white powder with the yield of $28 \mathrm{mg}$. It showed about $0.8 \%$ of CoA activity to phosphotransacety1ase of Clostridium kluyveri under the conditions employed ( $F \perp g$. 3). Hydrolysis of the isolated sample with CrotaIus adamanteus phosphodiesterase gave AMP and a sulfhydryl compound ( $R f, 0.65$ in solvent $I$ ). Ratio of adenosine : pantothenic acid : sulfhydryl : phosphorus was $1: 0.92: 0.91: 2.10$; required, 1: $1: 1: 2$. Other properties are shown in Table III.

\section{DISCUSSION}

It has now been found that a larger amount of CoA is able to be synthesized together with other metabolites of pantothenic acid such as $3^{\prime}$-dephospho-CoA and $4^{\prime}$-phosphopantothenic actd in the reaction mixture containing pantothenic acld, cysteine, AMP (or ATP), and a kind of microorganism. Thts process may provide an effective method for the preparation of CoA and 1 ts biosynthetic intermediates. Especlally, when labeled CoA Is required, it probably provides more sultable method than the methods reported by several authors (52-55), because of $1 \mathrm{tg}$ implicity and $1 \mathrm{ts}$ high converaion rate. Later, this method was applied to a synthesis of ${ }^{14} \mathrm{C}-\mathrm{CoA}$ (56).

Several yeasts showed the activity of CoA accumulation upon an addition of AMP. Its phosphorylated product, ATP, which is necessary for the blosynthesis of CoA, might be formed through the process of glucose fermentation in the yeasts (34). While, the accumulation of COA by bacterla was olcerved only when ATP was added.

Brevibacterium ammoniagenes IFO 12071 used here $1 \mathrm{~g}$ well known as the orgentsm which can synthesize not only nucleoside monophosphates, but also more complex nucleotides such as ATP, GTP, and so on $(57,58)$. Moreover, Nakayama et al. (59) have reported a salvage synthesis of pyridine coenzymes from nicotinic acid or nicotinamide and adenine in the culture broth using Brevibacterium ammoniagenes ATCC 6872. Therefore, it seems to be possible to accumulate CoA directly from pantothenic acid, cysteine, and adenine or AMP in the culture broth using the simflar system used in NAD synthesis. (This problem will be descrfbed in other sectlons).

Recently, Kuno et al. (29) have reported that several hydrocarbon assimilating microorganisms grown in pantothenate-supplemented medium accumulate intraceliularly a relatively large amount of CoA. They also improved the method for the extraction and that for the purification of CoA. Alberts et al. (60) reported that the cellular concentration of $\mathrm{COA}$ in pantothenaterequiring mutant of Eschrichia coli was directly related to the concentration of pantothenic acid in the medium. In the present study as indicated in Table II, several bacterla belonging to the genus of Brevibacterium contalned higher amount of CoA. Therefore, it would be also possible to make the accumulation of COA in higher level by culturing such bacteria in sultable pantothenate medium. 
Section II.

Formation of Coenzyme A by Baker's Yeast ${ }^{\text {) }}$

The posalblity for the formation of $\operatorname{COA}$ in a larger amount from pantothenlc acld and cysteine was investigated with baker's yeast under the condition coupled with ATP-generating system. Effect of varlous factors affecting the accumulation of CoA was investigated. Among them, glucose concentration and fnorganic phosphorus concentration were the most important factors for its accumulation. COA was not accumulated without phosphorylation of AMP to ATP. Several cationic surfactants stimulated the accumulation of CoA. The amount of COA accumulated reached about $200 \mathrm{Hg}$ per $\mathrm{ml}$ of the reaction mixture under the suitable reaction conditions.

\section{INTRODUCTION}

Mlcroorganfoms, espectally yeasts, are known to be one of the most suitable sources of CoA because of their easy supply in a larger amount at a lower cost. The extraction and the purification of CoA from microbial ceils have been reported by several workers $(20,21,25,29)$. However, Ifttle has been reported on the accumulation of COA with or without the addition of precursors such as pantothenic acid (10).

ATP is an essential cofactor for the blosynthesis of COA from pantothentc ac1d (14). The phosphorylation of AMP has been Investigated to obtain the higher yield of ATP with yeast cells by Tochikura et a1. (34). In the precedIng section, 1t has been demonstrated that several yeasts having the abilfty to phosphorylate AMP to ATP can accumulate CoA in the presence of pantothenic actd, cysteine, and AMP. Resting on the basis of this finding, the present Investigation is undertaken with baker's yeast to estimate the conditions of the accumulation of COA from pantothenic actd and cysteine for the coupling with ATP-generating system.

\section{MATERIALS AND METHODS}

Materials. Baker's yeast which was obtained from Oriental Yeast Co., Ltd., Tokyo, was used as an enzyme source throughout this work. Air-dried cells were prepared as described in Section $I$.
Acetone-dried cells and ground cells were prepared according to the method reported by Tochikura et ai. (34). An enzyme, which catalyzes the acetylation of sulfantlamide and is used for the determination of COA, was prepared from pigeon liver according to the method of Novell1 (61). Surfactants were kindly gifted from Sanyo Kase1 Co., Ltd., Kyoto, and from Kao Soap Co., Ltd., Tokyo. Other chemicals used were the same as those in Section I.

Standard reaction mixture for COA formation. The standard reaction mixture containing 167 pmoles of glucose, 15 umoles of AMP, 10 pmoles of sodium pantothenate, $10 \mu$ moles of cysteine, $200 \mu$ moles of potassium phosphate buffer, $\mathrm{pH} 7.0$, and $100 \mathrm{mg}$ of dried cells with or without an addition of Cation-s (cetyldimethylbenzylamonium chloride) surfactant in a total volume of $1 \mathrm{ml}$. The reaction was carried out as described in Section $I$, unless otherwlse stated.

Analytical methods. COA was assayed by. the phosphotransacetylase method of Stadtman et al. (43) using the enzyme of Eschrichia coli Crookes AKU 0001 as described in section I, or by the sulfanilamide acetylation method of Kaplan and Lipmann (62). Glucose, fructose 1,6-diphosphate, and 1norganic phosphorus were determined by the method of Somogy1 (63), Roe (64), and Takahash1 (65), respectively, Other saasys were 
the same as those described in section I.

\section{RESULTS AND DISCUSSION}

Effect of the preparation method of cells on the formation of $C O A$

As shown in Table $I$, the amount of CoA in the reaction mixture greatly increased only in the complete system. The onissions of each substrate gave a slight or no lncreased formation of CoA. It was found that the amount of CoA formed differed with yeast prepara-

TABLE I. REQUIREMENT OF PANTOTHENIC ACID, CYSTEINE, GLUCOSE, AND AMP FOR COA FORMATION

The complete reaction condition is described in the text. The reaction was carried out for $5.5 \mathrm{hr}$ under the standard conditions except that each reaction component was onicted as Indicated.

\begin{tabular}{|c|c|c|}
\hline \multirow[b]{2}{*}{ Condition } & \multicolumn{2}{|c|}{$\mathrm{COA}$ found $(\mu \mathrm{g} / \mathrm{ml})$} \\
\hline & $\begin{array}{l}\text { before } \\
\text { reaction }\end{array}$ & $\begin{array}{l}\text { after } \\
\text { reaction }\end{array}$ \\
\hline Complete & 29 & 134 \\
\hline $\begin{array}{l}\text { Onit pantothenic acid } \\
\text { and cysteine }\end{array}$ & 28 & 25 \\
\hline onit pantothenic acid & 30 & 33 \\
\hline Oolt cysteine & 35 & 66 \\
\hline Owit glucose & 32 & 43 \\
\hline Onit AMP & 33 & 60 \\
\hline Ontt cells & 0 & 0 \\
\hline $\begin{array}{l}\text { Cells in potassium phosphate } \\
\text { buffer, pH } 7.0\end{array}$ & 28 & 20 \\
\hline
\end{tabular}

TABLE II. EFFECT OF PREPARATION METHOD OF CELLS ON COA FORMATION

The reactions vere carried out for $6 \mathrm{hr}$ under the standard conditions except that ccl1s as enzye source used were as indicated. The aurfactant concentration was 1 mg per ml.

\begin{tabular}{lc}
\hline Cells used (100 mg/ml) & $\begin{array}{c}\text { CoA formed } \\
(\mu \mathrm{g} / \mathrm{ml})\end{array}$ \\
\hline Acetone dried cells & 110 \\
Acetone dried cells with tween 60 & 105 \\
Acetone dried cells with CPC & 211 \\
Intact cells & 60 \\
Intact cells with Tween 60 & 62 \\
Intact cells with CPC & 101 \\
Afr dried cells & 88 \\
Ground cells & 102 \\
\hline
\end{tabular}

CPC: cetylpytidinium chloride. tions which were treated by several methods (Table II). Ground cells, acetone-dried cells, and air-dried cells could form relatively large amounts of CoA. In the reaction system with intact cells, the amount of CoA dId not increase after the incubation. It was also found that the addition of a certa1n surfactant to both systems of 1ntact cells and acetone-dried cells was effective on the accumulation of CoA. These results may suggest that the formation of CoA occurred only when the injured cella were used. However, it is not clear, at present, whether CoA was formed in an extracellular system or not. Tochtkura et al. (66) have obsreved that some enzymes concerning UDP-hexose formation from UMP and glucose under the fermentation conditions of alr-dried cells of Torulopsis candida leak out into the supernatant of the reaction mixture. The similarity of the fermentation conditions in the present case to that of UDP-hexose formation suggests that the formation of CoA occurred extracellularly. In the following experiments, acetone-dried cells were used matnly because of its simplicity for the obtain of the constantly active preparations.

Effect of substrates on the formation of $\operatorname{CoA}$

Glucose concentration and other sugars. The optimum concentration of glucose for the formation of $\operatorname{CoA}$ was 167 to 333 umoles per ml of the reaction mixture (Fig. 1). At higher levels of glucose, the AMP added was matnly metabolized to yteld adenosine and IMP accompanied with the repressed formatIon of COA, although the fermentation of glucose was very active. The addition of sucrose or fructose as an energy source showed the same effect as glucose on the formation of CoA. These sugars probably entered to glycolytic pathway and resulted the formation of ATP. A weak fermentation and neither formation of ATP nor CoA were observed by an addition of other sugars such as galactose, xylose, glycerol, and a-glycerophosphate in place of glucose. 


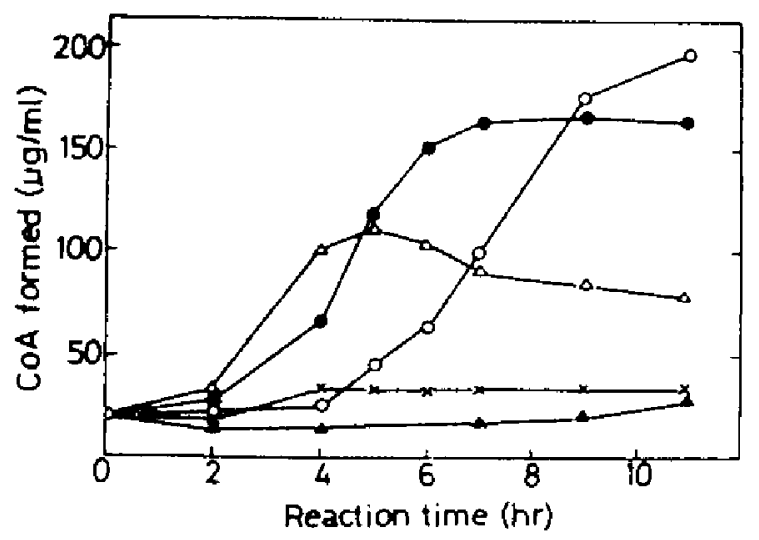

FIG. 1. Time Courbe for CoA Formation under Various Glucoae Concentrations.

The reactien was carrled out under the standard conditions except that glucose concentration was varled as follows: $x$, Hthout

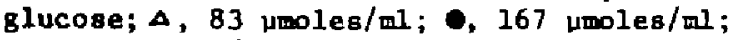
O 333 umoles/ml; 4,1111 moles/ml. Cation-S concentration was $0.5 \mathrm{mg} / \mathrm{ml}$.

Pantothenic acid. The amount of CoA in the reaction mixture increased with an Increased addition of pantothenic acld, but the rate of conversion from pantothenic acid to COA decreased logarttholcally. As shown in Table III, pantethine was about 2.0-fold as active as pantothenic acid. It seemed that the phosphorylation of pantethine (pantetheine) might occur and the resulted product entered to the pathway for the blogynthesis of COA.

TABLE III. COMPARISON OF COA FORMATION FROM PANTOTHENIC ACID AND PANTETHINE

The reaction was carrled out for $7 \mathrm{hr}$ under the standard conditions by an addition of each compound as indicated instead of pantothenic acid. Cation-S was also added to the reaction wixture at the concentration of $0.5 \mathrm{mg}$ per ml.

\begin{tabular}{lc}
\hline Compound (umoles/ml) & $\begin{array}{c}\text { CoA formed } \\
\text { (ug/m1) }\end{array}$ \\
\hline Pancothenic acid (10) & 115 \\
Pantothenlc acid (10) + pantethine (5) & 270 \\
Pantethine (1.5) & 227 \\
Pantethine (5) & 225 \\
\hline
\end{tabular}

Cysteine. The optimum concentration of cysteine for the formation of CoA was about 10 to 20 umoles per $m$ l of the reaction mixture. At higher levels of cystelne, the consumption of glucose and the formation of ATP were strongly 1nhib1ted. The decarboxylated product of cysteine, 2-mercaptoethylamine, which is also able to couple with $4^{\prime}-$ phosphopantothenlc acld to yleld 4'phosphopantethelne (14), was tested as a substrate for the CoA aynthesis. It was about two-third as active as cystelne. Brown (14) reported that both of bactertal and mammallan coupling enzymes, which catalyze the coupling of $4^{\prime}$-phosphopantothenic acid with cysteine, can transform $4^{\prime}$-phosphopantothenic acid and 2-mercaptoethylamine to $4^{\prime}$-phosphopantetheine.

AMP concentration and other nucleotides. The amounts of CoA and ATP in the reaction mixture increased with an increase of AMP concentration. The amount of CoA reached more than $200 \mathrm{\mu g}$ per ml of the reaction mixture with an addition of 54 umoles per ml. When the direct precursor of COA, ATP, was added instead of AMP at the start of the reaction, the formation of CoA was greatly stimulated. When glucose as an energy source was omitted, the ATP added was immediately degraded to IMP and the formation of CoA did not occur. Subsequently, the effects of other nucleotides and thelr related compounds on the formation of CoA were examined.

IABLE IV. PORMATION OF COA USING SEVERAL NUCLEOT IDE-RELATED COMPOUNDS

The reaction was carried out for 7 hr under the otandard conditions by an addition of each compound as indicated 1ngtead of AMP. Cation$S$ was also added to the reaction mixture at the concentration of $0.5 \mathrm{mg}$ per ml.

\begin{tabular}{lc}
\hline $\begin{array}{c}\text { Nucleotide-related } \\
\text { compound added } \\
(10 \text { umoles/ml) }\end{array}$ & $\begin{array}{c}\text { CoA formed } \\
\text { (ug/mi) }\end{array}$ \\
\hline Adenine & 45 \\
Adenosine & 99 \\
AMP & 126 \\
ADP & 163 \\
ATP & 175 \\
GPP & 94 \\
CMP & 36 \\
UAP & 35 \\
IMP & 42 \\
\hline
\end{tabular}


The reault is summarized in Table IV. of the adenine-contalning compounds tested, ATR was the most effective, and $A D P, A M P$, and adenosine, which were well phosphorylated to ATP, were less effective than ATP In this oder. Neither the phosphorylation to ATP, nor the formation of CoA was observed with an addition of adenine ingtead of AMP. Among other nucleotides tested, only GMP had a little effect on the formation of CoA. In this case, GMP was we11 phosphorylated to GTP without the formation of ATP in a detectable amount. It might be possible that GTP derlved from GMP functioned as a direct energy source of $C O A$ synthesis in a similar manner to the ATP function. Brown (14) reported that CTP 1 s an energy source for the coupling reaction between $4^{\prime}-$ phosphopantothenic acld and cystelne in bacterlal system. Kitajima et al. (67) reported that CMP can be phosphorylated to CTP under the simllar fermentation condition of yeasts to that of the phosphorylation of AMP. In order to examine the supplementary effect of CTP, both AMP and CMP were added to the reaction mixture. The AMP and the CMP were well phosphorylated to the corresponding triphosphates, but further increased formation of CoA than that of AMP-only was not observed. This suggests that CTP may be specific only for bactertal enzyme, and the coupling enzyme of yeast may be resemble to mammalLan enzyme rather than bacterial enzyme.

other factors affecting the accumulation of $C O A$

The accumulation of CoA was accelerated wth an increasing concentration of 1norganic phosphorus up to 200 moles per $\mathrm{ml}$ of the reaction mixture. The amount of $C O A$ formed in the reaction mixture reached $150 \mu \mathrm{g}$ per ml at the concentration of 200 jmoles per ml. At higher concentrations of inorganic phosphorus, the consumption of glucose was atrongly inhibited. While, at the lower concentrations, deamination of AMP was very accelerated. The feeding of inorganic phosphorus during the 1ncubation did not show the influence to the accumulation of COA.

The $\mathrm{pH}$ optimum of the reaction was between 6.5 and 7.0. The complete Inhibition of glucose fermentation was observed at the higher pBs. The sultable temperature of the reaction for the accumulation of $\mathrm{CoA}$ ras about $37^{\circ} \mathrm{C}$. The accumulation of $\mathrm{CoA}$ was further accelerated by an aerobical condition accompanied with the activation of glucose fermentation and that of AMP phosphorylation.

Effect of divalent catlons on the accumulation of $C O A$ was investigated. Among the cations tested, $\mathrm{Mg}^{2+}$ and $\mathrm{Mn}^{2+}$ showed the stimulative effect on the accumulation of CoA, and shortened the reaction period, But $\mathrm{Ca}^{2+}, \mathrm{Cu}^{2+}, \mathrm{Zn}^{2+}$, and $\mathrm{Fe}^{2+}$ were all inhibitory. Magnesium fon probably acted as a cofactor not onily in the process of the blosynthesis of CoA, but also in glycolytic pathway.

The results obtafned above suggests that the formation of ATP, which probably occurred in preference to the accumulation of COA, was affected by the factors such as glucose concentration, magnestum ion, and so on. Then, the accumulation of CoA might be brought about secondarlly through the accumulation of ATP.

Effect of surfactant on the accumulation of COA

A certain surfactant stimulated the accumulation of CoA as described above. Then, numerous surfactants which included cationics (12), antontcs (8), nonlonics (14), and amphoterics (4) were tested using the intact cells and the acetone-dried cells. It was found that all the catlonics tested were effective in both yeart preparationg, Among them, cetyltrimethylammonium chlortde, cetylethyldimethylamonium bromide, cetylpyridintum chloride, and Cation-s gave the higher yields of CoA (Table V). The optimm concentration of the surfactant was observed at 1.0 to $1.2 \mathrm{mg}$ per ml of the reaction mixture. At higher concentrations of the surfactant, both ATP and CoA were not formed because of its atrong inhibitory effect on the fermentation of glucose. As shown in 
TABLE Y. EPPECT OF SURFACTANT ON COA ACCURTLATION

The reaction wa carried out under the standerd conditlons ualng acetone dried cells by an addition of each surfactant as indicated.

\begin{tabular}{|c|c|c|c|c|}
\hline \multirow[t]{2}{*}{ Surfactant (1 mg/al) } & \multicolumn{4}{|c|}{$\begin{array}{c}\text { Con found }(\mu g / m l) \\
\text { after }\end{array}$} \\
\hline & 0 & 4 & 5.5 & $7(\mathrm{hr})$ \\
\hline $\begin{array}{l}\text { Hone } \\
\text { Tween } 60\end{array}$ & $\begin{array}{l}25 \\
24\end{array}$ & 68 & $\begin{array}{l}95 \\
90\end{array}$ & 40 \\
\hline Tween 80 & 30 & - & 110 & 64 \\
\hline Span 60 & 25 & 80 & 45 & 37 \\
\hline SodIum oleate & 25 & 131 & 80 & 55 \\
\hline Sodium sterrate & 26 & 55 & 87 & 59 \\
\hline $\mathbf{K L S}$ & 24 & 31 & 36 & 31 \\
\hline SLP & 25 & 82 & 60 & 38 \\
\hline CPC & 25 & 41 & - & 190 \\
\hline LPC & 28 & - & 55 & 105 \\
\hline STAC & 21 & 55 & 135 & 145 \\
\hline CTAC & 24 & - & 67 & 202 \\
\hline CTAB & 20 & 133 & - & 153 \\
\hline LTAC & 34 & - & 90 & 155 \\
\hline CEAAB & 35 & - & 120 & 197 \\
\hline Cacion-s & 23 & 52 & - & 206 \\
\hline Lebon GM & 24 & 45 & 111 & 191 \\
\hline Lebon 15 & 20 & 110 & - & 115 \\
\hline
\end{tabular}

- not teated.

Abbreviations used: KLS, potassium lauryloulfate; SLP, sodium laurylphosphate; CPC, cetylpyridintum chloride; LPC, laurylpyridinium chloride; STAC, stearyitrinethylammontum chloride; CTAC, cetylt Imethylammon Iur chloride; CTAB, cetyltrimethylamonim bromide; LTAC, lauryltrimethylammontum chloride; CEMAB, cetylethy 1 dimethylanmon 1 um browide; Lebon GM, lauryldimethylbenzy lammonium chloride; Lebon 15, sodium alkyldi (aminoethyl)glycine.

F1g. 2, the additions of the surfactant at early reaction perlods was more effective than those at the later periods. The stability of pure CoA solution was not affected by the presence of the surfactant. It has been reported that some surfactants bring the serlous affect to enzyme structures or enzyme actIons (68-70). It has been also observed that several surfactants give effective actions to the extraction of compounds from microbial cells (71), and that some enzymes or some metabolic products leak out in the presence of surfactant (72-74). In the present case, however, it is difficult to decide which the effect was caused (represston of enzymatic degradation of CoA? stimu-

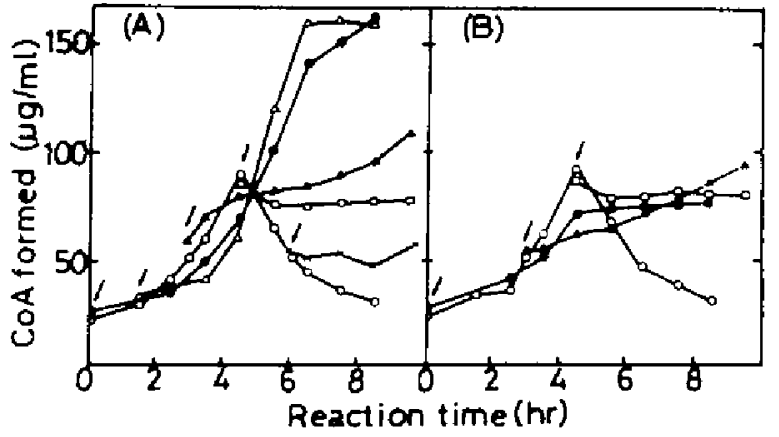

FIG. 2. Bffect of Cation-S Surfactant on CoA Accumulation.

The reaction was carried out under the standard conditions except that Cation-S ras added at the time indicated by the arrows at the concentration of $1.5 \mathrm{mg} / \mathrm{ml}$ (A) and $2.5 \mathrm{mg} / \mathrm{ml}$ (B), respectively, $O$ : control run (without Cation-S).

lation of CoA synthesizing enzymes? or simple extractive offect to the reaction products?).

Time course of the reaction

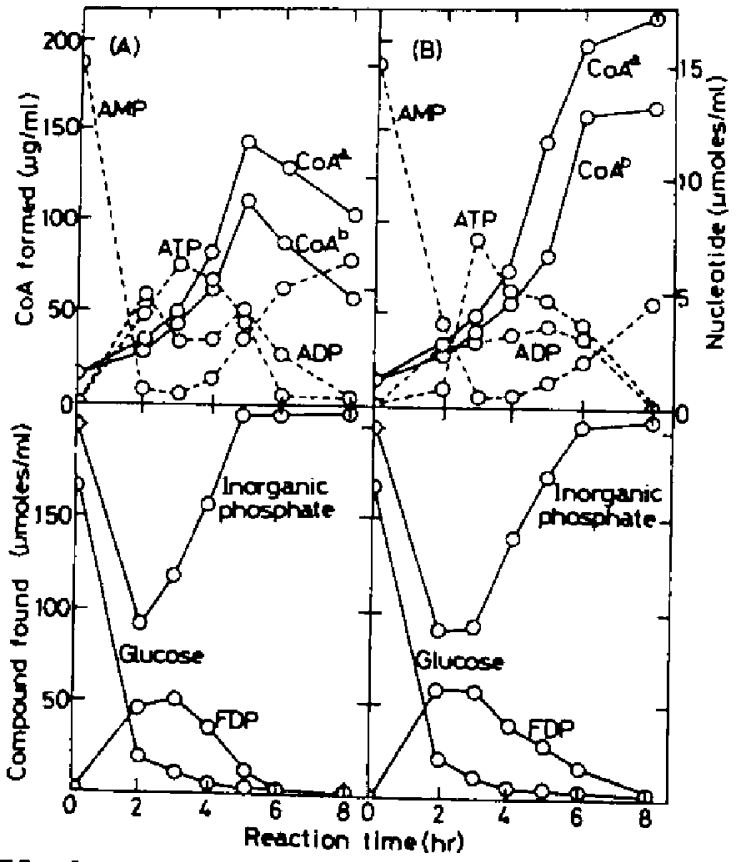

FIG. 3. Formation and Consumption of Several Compounds in the Reaction Mixture.

The reaction was carried out under the standard conditions with (A) or whout (B) $1.5 \mathrm{mg}$ of Cation-S surfactant. COA was assayed by the sulfanilamide acetylation method of Raplan and Lipmann (62) (a); and by the phosphotransacetylase method of Stadtman et al, (43) (b). FDP: fructose 1,6-diphosphate. 
The time course of the formation of products and the consumption of substrates in the reaction mixture is shown in Fig. 3. The consumption of glucose, Inorganic-phosphorus, and AMP occurred first, then the accumaltion of fructose 1,6-diphosphate and ATP, and finally CoA accumulation. The remarkable decrease of Inorganic phosphorug in the reaction mixture prior to the accumulation of CoA suggests that 1 t might be Incorporated into fructose 1,6-diphosphate, a key intermediate in the glycolytic pathway, which might be, then, further metabolized to yield further ATP.

When the amount of CoA formed in the reaction mixture was assayed by both of the phosphotransacetylase method of Stadtman et al. (43) and the sulfanilamide acetylation method of Kaplan and L1pmann (62), the amount of CoA detected was higher in the latter case than that in the former (FIg. 3). It seems that the result might be attributed to the lower specificity of the latter method for the intermediates of $\mathrm{CoA}$ blosynthesis. 
Section III.

Formation of Coenzyme A by Brevibacterium ammoniagenes IFO 1207] d)

Several conditions for the formation of CoA from pantothenic actd and cyateine in the presence of ATP were lnvestigated using Brevibacterium anmoniagenes IFO 12071. The higher activity of the formation of CoA was observed with the cells grown in acetate media. The effects of the substrate concentration, phosphate buffer concentration, $\mathrm{pH}$, and cell concentration on the formation of CoA were examined and the amount of $\mathrm{COA}$ formed reached a maximum value of 1.2 mg per $\mathrm{ml}$ of the reaction mixture. Several surfactants belonging to cationics and anionics brought about 1.8-fold stimulation of COA formation. The considerable accumulation of $\mathrm{COA}$ in the culture broth during the growth was also observed.

\section{INTRODUCTION}

In the previous sections, it has been demonstrated that dried cells of several kinds of microorganisms, especlally, Brevibacterium ammoniagenes IFO 12071, formed a larger amount of CoA and 1 tg blosynthetic intermedtates from pantothentc acld and cystelne in the presence of AMP or ATP. The isolation and the characterlzation of COA, $3^{\prime}$-dephospho-COA, and 4'-phosphopantothenic ac1d formed in the reaction mixture were also described.

In the present section, the effects of varfous factors on the formation of CoA by Brevibacterium ammoniagenes IFO 12071 are Investigated.

\section{MATERIALS AND METHODS}

Microorganism and cultivation. Brevibacterium ammoniagenes IFO 12071 was used throughout this work. The culture techniques were the same as described in Section I, unless otherwlse stated.

Preparation of aried cells. Dried cells of the bacterfum were prepared as described in Section I.

Chemicals. 4'-phosphopantothenic acid and 3'-dephospho-CoA were prepared as described in Section $I$. Other chemlcals used were the same as those described in Section I.

Standard reaction condition for COA formation. The standard reaction $\mathrm{mlx}-$ ture contained 10 moles of sodium pantothenate, $10 \mu$ moles of cysteine, 15 Hmoles of ATP, 10 imoles of $\mathrm{MgSO}_{4}, 150$ $\mu$ moles of potassium phosphate buffer, $\mathrm{pH} 6.0$ or 7.0 , and $100 \mathrm{mg}$ of air-dried cells of Brevibacterium ammoniagenes in a total volume of I ml. All other conditions were the same as those described In Section I, unless otherwise stated.

Analytical methods. The analytical methods employed here were the same as those described in section $I$.

\section{RESULTS}

Formation of COA by air-dried cells

Culture conditions for the preparation of cells. In order to know whether the activity of COA synthesis is varied by growth conditions or not, the cultivations were carrled out with various media. The stronger activity of CoA formation was found in the cells grown in glucose media and in acetate media. Results are summarized in Table I. The cells from acetate- $\mathrm{NH}_{4} \mathrm{Cl}$ medium consumed about $40 \%$ of the pantothenic acid added and accumulated $1.2 \mathrm{mg}$ of COA per $\mathrm{ml}$ of the reaction mixture (The conversion rate to the pantothenic actd added was 15.7\%.) under the standard conditions. However, the growth of the organism in acetate media was relatively slow and weak, then the cells grown in glucosepeptone medium were malnly used in the 
TABLE I. EFTECT OF CULTURE CONDITIONS FOR THE PREPARATION OP CELLS ON COA FORMATION

The cultivation was cartied out aerobically at $28^{\circ} \mathrm{C}$ for 60 hr with the medium which composed of 38 of carbon source as indlcated, 0.5 of nitrogen source as Indicated, $0.2 \mathrm{~g}$ of $\mathrm{K}_{2} \mathrm{HPO}_{4}, 0.1$ g of $\mathrm{KH}_{2} \mathrm{PO}_{4}, 0.28$ of $\mathrm{NaCl}, 0.02$ 8 of $\mathrm{MgSO}_{4} \cdot 7 \mathrm{H}_{2} \mathrm{O}, 0.1 \mathrm{~g}$ of yeast extract, and $100 \mathrm{ml}$ of tap water, $\mathrm{pH} 7.0$. n-Paraff 1 n used contalned $C_{13}, 0.47 ; C_{14}, 68.17 ; C_{15}, 29.97$; $C_{16}, 0.87$; and aromatics, $1.3 \%$.

The activity of COA formation was measured as described in the text with the reaction time for $5 \mathrm{hr}$.

\begin{tabular}{|c|c|c|}
\hline Med Ium ${ }^{a)}$ & $\begin{array}{l}\text { CoA found } \\
\text { before } \\
\text { reaction }\end{array}$ & 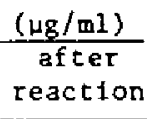 \\
\hline $\begin{array}{l}\text { Glucose-peptone } \\
\text { Glucose-urea } \\
\text { Glucose-NH } 4 \mathrm{Cl} \\
\text { Sod1um acetate-peptone } \\
\text { Sod lum acetate-NH4 Cl } \\
\text { Glycerol-peptone } \\
\text { n-Paraffin-peptone }\end{array}$ & $\begin{array}{r}15 \\
15 \\
10 \\
16 \\
55 \\
15 \\
5\end{array}$ & $\begin{array}{r}566 \\
500 \\
573 \\
790 \\
860 \\
265 \\
0\end{array}$ \\
\hline
\end{tabular}

a) A very veak growth or no growth was obserbed in sodfum acetate-urea, glycerol-urea, glycerol- $\mathrm{NH}_{4} \mathrm{Cl}, n$-paraff in-urea, and $n$ paraffin- $\mathrm{NH}_{4} \mathrm{Cl}$ under the conditions tested.

following experiments. The relationsh1p between the activity of CoA synthesis and the growth phase of the organtem in glucose-peptone medium was investigated. For this experiment, cells were cultivated at $28^{\circ} \mathrm{C}$ for 15 to $108 \mathrm{hr}$. The activity of CoA synthesis was almost constant in the range tested.

Reaction conditions. Several reactIon conditions for CoA formation were Investigated with the cells grown in glucose-peptone medium for $24 \mathrm{hr}$. i) Effects of pantotheric acid, cysteine, and ATP concentration. As shown in Fig. 1, at the concentration of 1 pmole of pantothenlc acid per ml of the reaction mixture about $85 \%$ of the pantothenic acid added was converted to CoA. The amount of CoA Increased with an increased addition of pantothenic acid up to 10 umoles per m1. Further addition of pantothenic acid brought a decrease of CoA formation. On the other hand, cyatelne requirement for the maximum formation of $\mathrm{COA}$ was more than 10 umoles per $m 1$. The amount of COA formed in

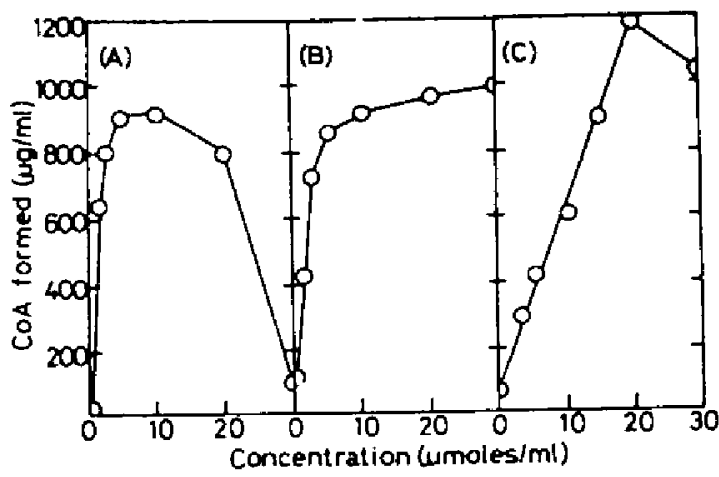

FIG. 1. Effect of Substrate Concentration on CoA Formation.

Each reaction was carried our under the standard conditions for $5 \mathrm{hr}$ except that pantothenic acid (A), cysteine (B), or ATP (C) was varled at the concentration as Indicated.

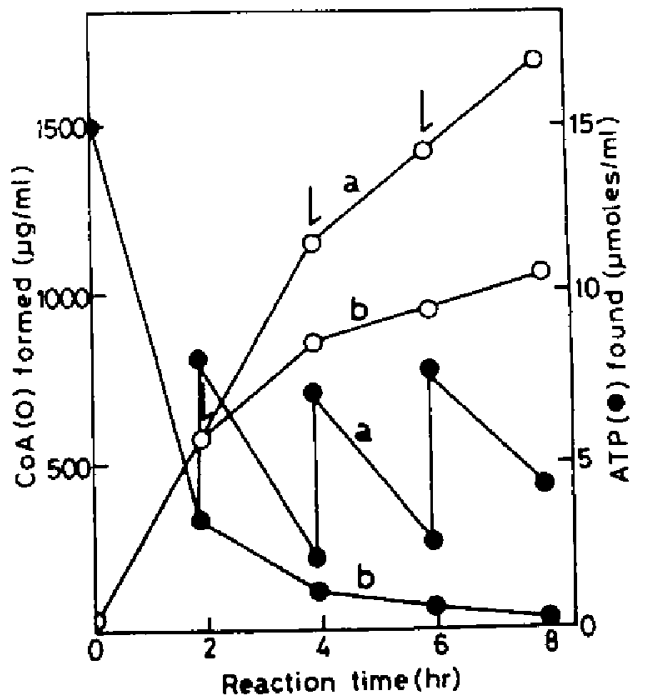

FIG. 2. Effect of ATP Supplying on CoA Formation.

The reaction was carried out under the standard conditions except that 5 wmoles of ATP were added at the time indicated by the arrows in the case of (a). (b) $1 \mathrm{~s}$ a control run.

the reaction mixture increased 1 inearly up to $20 \mu$ moles of ATP per $\mathrm{ml}$ and reached a maximum value of $1.2 \mathrm{mg}$ per ml. It seemed, consequently, ATP concentration IImited the formation of CoA rather than those of pantothenic acld and cysteine under the conditions tested. The supply of ATP during the incubation brought the increase in the amount of COA formed (Fig. 2). Plerpoint et al. (75) reported that the phosphorylation of 
pantothenic acid by dried cells of Lactobacillus arabinosus was 1.4-fold actIvated by an addition of $\mathrm{NaF}$, and they auggested the presence of ATPases in the cells. In the present case, however, the reaction was not affected by an addition of NaF or KCN as phosphetase tnhibitor.

11) Phosphate buffer concentration. Relatively higher activity was found beween 90 and $200 \mathrm{mM}$ of potassium phosphate buffer, $\mathrm{pH} 6.0$. At lower phosphate concentrations, the conversion of the ATP added to adenine and adenosine was observed, while these compounds were not detected from the reaction mixture at the concentrations of $90 \mathrm{mM}$ and over. At the higher concentrations of phosphate, the ATP added remained without ita utilization for CoA formatIon.

iii) $p H$. It was observed that the reaction had a pH optimum between 6 and 6.5. Of the buffers used, potassium phosphate buffer was the most suitable for the formation of CoA, while Tris buffers were rather inhibitory. iv) Cell concentration. The cell concentrations of 100 to $150 \mathrm{mg}$ per ml of the reaction mixture were effective on the formation of CoA. It seemed that degradation of the product was caused at the concentration of $200 \mathrm{mg}$ per $\mathrm{ml}$ and by longer reaction time. The lower concentrations of the cells (less than $40 \mathrm{mg}$ per m1) gave only negligible formation of CoA. At least, $50 \mathrm{mg}$ of the cells per $m l$ were required for the formation of $\mathrm{CoA}$.

v) Hetal ion requirement. Among the cations tested, $\mathrm{Mg}^{2+}$ showed a slight acceleration for the formation of CoA. Magnesium 1on 18 known to be a cofactor throughout the pathway for the biosynthesis of CoA. The result obtained here nay ouggeat that the suffictent amount of $\mathrm{Mg}^{2+}$ to aynthesize CoA was present in the cells. It was also observed that the formation of CoAwas strong1y inhibited by the additions of 10 umoles of $\mathrm{Cu}^{2+}, \mathrm{Co}^{2+}$, and EDTA per $\mathrm{ml}$, respectively.

vi) Temperature. The optimum temperature of the reaction was in the range frow 37 to $42^{\circ} \mathrm{C}$. Under h1gher temperatures than $45^{\circ} \mathrm{C}$, the formation of CoA was completely repressed.

vii) Effect of various compounds relating to COA bfosynthesis. Among the nucleotides tested, only ATP was active for the formation of COA. CTP has been known as an energy source for the coupling of $4^{\prime}$-phosphopantothen1c ac1d with cysteine in bacterlal systems such as Eschrichia coli and proteus morganit (14). In the present case, the supplementary effect of CTP was very slight when compared with that of ATP-only in this experiment (Table II). While, 4'-

TABLE II, EFFECT OF NUCLEOTIDES ON COA FORMATION

The reaction was carried out for $6 \mathrm{hr}$ under the standard conditions by an addition of each rucleotide Instead of ATP.

\begin{tabular}{lc}
\hline $\begin{array}{l}\text { Nucleotide } \\
\text { ( } \mu \text { moles } / \mathrm{ml})\end{array}$ & $\begin{array}{c}\text { CoA formed } \\
\text { ( } \mathrm{gg} / \mathrm{ml})\end{array}$ \\
\hline None & 221 \\
ATP (15) & 815 \\
ADP (15) & 281 \\
AMP (15) & 215 \\
GTP (15) & 362 \\
GDP (15) & 314 \\
CTP (15) & 367 \\
UTP (15) & 358 \\
ITP (15) & 367 \\
ATP (15) + CTP (10) & 928 \\
ATP (15) + CTP (5) & 896 \\
\hline
\end{tabular}

phosphopantothenic acid was completely converted to 4'-phosphopantethe1ne by the cell suspension of Brevibacterium ammoniagenes IFO 12071 in the presence of CTP and cysteine, but not ATP and cystelne, which will be described in other sections. Among the sulfhydryl donor tested, L-cystine was active as well as L-cysteine, but D-cysteine was not active. 2-Mercaptoethylamine was Inactive under the conditions tested. As shown in Table III, pantethine, 4'phosphopantothenic acid, and $3^{\prime}$-dephospho-CoA were also converted to COA with higher conversion rates than that of pantothenic acid. Pantothenyl alcohol, which is an alcohol analog corresponding to pantothenic acid, was not converted to CoA. 
TARLE III. PORMATION OF COA FROM PAKTOTHERATE DERIVAT I VES

The reaction was carried out for $8 \mathrm{hr}$ under the atandard condiclons by additione of $2 \mathrm{mg}$ of rodiun laurylbenzenerulfonate and of each substrate instead of pantothentc acld.

\begin{tabular}{|c|c|}
\hline Compound (mooles/ml) & $\begin{array}{c}\text { CoA formed } \\
(\mu g / m l)\end{array}$ \\
\hline $\begin{array}{l}\text { Pantothenic acid (10) } \\
\text { Pancothengl alcohol (10) } \\
\text { Pantethine (5) } \\
\text { 4'-Phosphopantotbenic acid (10) } \\
\text { 3'-Dephospho-CoA (10) }\end{array}$ & $\begin{array}{r}2051 \\
79 \\
2480 \\
3978 \\
6997\end{array}$ \\
\hline
\end{tabular}

Formation of CoA by intact cell system and growing cell system

Effect of surfactant on several cell preparations. The stimulative effect of surfactants on CoA accumulation by baker's yeast was described in Section II. In this experiment, several surfactants were tegted. The result is shown in Table IV. The remerkable st1mulation to the accimulation of CoA by some of them belonging to cationics and antonics was observed. On the other hand, nonlonics employed here showed no simulative effect. The concentrations of 1 to $2 \mathrm{mg}$ of sodium laurylbenzenesulfonate or sodium laurylsulfate per
TABLE IV. EFFECT OF SEVERAL SURPACTANTS ON COA PORKATION

The reaction was carried out under the standard conditions for $B$ hr with an addition of each surfactant as indicated.

\begin{tabular}{lc}
\hline \multicolumn{1}{c}{ Surfactant (1 mg/ml) } & $\begin{array}{c}\text { CoA formed } \\
(\mu g / m l)\end{array}$ \\
\hline None & 1025 \\
Span 60 & 1031 \\
Tween 80 & 1011 \\
Cetylbenxyldimethylammonium chloride & 1028 \\
Stearyltrinethylammontum chloride & 1086 \\
Cetylpyridintum chloride & 1690 \\
Sodium laurylbenzenesulfonate & 1875 \\
Sodium lauryl gulfate & 1725 \\
Sodium cetylgulfate & 1390 \\
Sodim laurylphosphate & 1294 \\
Sodium laurate & 1269 \\
\hline
\end{tabular}

ml gave the good CoA accumulation. At the concentration of $2 \mathrm{mg}$ per $\mathrm{ml}$, the amount of COA formed rose to about 1.3-fold when compared with no addition of surfactant. Further addition of surfactant caused the Inhibitory effect. This stimulative effect of surfactant was also observed In intact cell system, acetone-dried cell system, and this effect was most remarkable in intact cell system. In intact cell system, it was found that the fomation of CoA and

TABLE V. EFFECT OF SURFACTANT ON SEVERAL CELI PREPARATIONS

The reaction mixture containing 5 Hmoles of sodium pantothenate, 10 mmoles of cysteine, 15 moles of ATP, 10 moles of $\mathrm{MgSO}_{4}, 150$ wroles of potassium phosphate buffer, $\mathrm{pH} 6.0$, and each cell preparation as indicated was incubated with or whout $1 \mathrm{mg}$ of sodium lauryloulfate (SLS) for $6 \mathrm{hr}$ at $37^{\circ} \mathrm{C}$ in a total volume of $1 \mathrm{ml}$. The amounts of the cells added into the resction mixture were $54 \mathrm{mg}, 100 \mathrm{mg}$, and $100 \mathrm{mg} 1 \mathrm{~A} \mathrm{~A}, \mathrm{~B}$, and $C$, respectively. In the case of $D$, the reaction mixture containing 0.1 unole of sodium pantothenate, 5 umoles

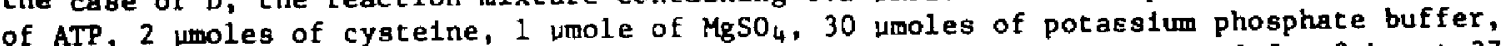
$\mathrm{pH} 6,0$, and $0.3 \mathrm{ml}$ of cell free extract was incubated with or without sLS for 2 hr at $37^{\circ} \mathrm{C}$ in a total volume of $1 \mathrm{ml}$.

\begin{tabular}{|c|c|c|c|c|}
\hline Preparation & $\begin{array}{c}\text { SLS } \\
\text { added } \\
\text { (mg) }\end{array}$ & $\begin{array}{l}\text { CoA formed } \\
\text { ( } \mu \text { moles) }\end{array}$ & $\begin{array}{l}\text { Remaining pan- } \\
\text { tothentc acid } \\
\text { (umoles) }\end{array}$ & $\begin{array}{c}\text { Rempining ATP } \\
\text { (umoles) }\end{array}$ \\
\hline A. Intact cells & 0 & 0.14 & 4.80 & 14.0 \\
\hline " & 1.0 & 1.18 & 0.60 & 0.5 \\
\hline B. A1r dried cells & 0 & 1.19 & 1.30 & 0.5 \\
\hline " & 1.0 & 2.05 & 0.20 & 0.5 \\
\hline c: Acetone dried cells & 0 & 1.60 & 0.95 & 0.3 \\
\hline & 1.0 & 1.75 & 0.54 & 0.0 \\
\hline D. Cell free extract & 0 & 0.10 & 0.00 & 0.0 \\
\hline i & 0.2 & 0.09 & 0.00 & 0.0 \\
\hline$"$ & 1.0 & 0.03 & 0.05 & 0.0 \\
\hline
\end{tabular}


the consumption of ATP did not occur without the addition of surfactant. On the other hand, the addition of surfactant brought rather 1ahibltory effect to the formation of COA 1 in cell free system (Table $V$ ). These facts suggest that COA might be accumulated only by the infured cell preparations. In the experiment to examine the extracellular excretion of the enzymes relating to CoA blosynthesis, the futact cells were contacted with sodium lsurylsulfate in $0.05 \mathrm{M}$ potassium phosphate buffer, $\mathrm{pH}$ 6.0 for 2 hr at $37^{\circ} \mathrm{C}$, and then the actIv1ty of pantothenate kinase in the supernatant was measured. But the algn1ficant activity was not detected.

Direct accumulation of COA in culture broth. Because the formation of CoA occurred using the intact cells and surfactant system as demonstrated above, an attempt to accumulate $C O A$ in the culture broth during the growth with an addition of adenine derivative was brlefly done. The bacterium produced a large amount of CoA whin it was grown in the medium containing CoA pre-

TABLE VI. ACCURULATION OF COA IN CULTURE BROTH DURING THE GROWTH

Cultivation was carried out in $500 \mathrm{ml}$ shaking flagk containing $20 \mathrm{ml}$ of the medium of Tanaka et $\mathrm{a} 1$. ( 58 ), which contained $2 \mathrm{~g}$ of glucose, $0.12 \mathrm{~g}$ of urea, $0.2 \mathrm{~g}$ of $\mathrm{KH}_{2} \mathrm{PO}_{4}, 0.2$ $\mathrm{g}$ of $\mathrm{K}_{2} \mathrm{HPO}_{4}, 0.2 \mathrm{~g}$ of $\mathrm{MgSO}_{4} \cdot 7 \mathrm{H}_{2} \mathrm{O}, 0.2 \mathrm{~g}$ of yesst extract, $2 \mathrm{mg}$ of $\mathrm{CaCl}_{2} \cdot 2 \mathrm{H}_{2} \mathrm{O}$, and $0.6 \mathrm{Hg}$ of blotin. After 3 day cultivation at $28^{\circ} \mathrm{C}$, $30 \mathrm{mg}$ of sodium pantothenate, $40 \mathrm{mg}$ of cysceine, $40 \mathrm{mg}$ of adenine derivative as indicated, and $20 \mathrm{mg}$ of cetylpyridinium chloride (CPC) vere added to the medium, except that in the case of $A$ and $D$, the adenine derlvative was added before the cultivation, and in the case of C, CPC was omitted. Then the cultivat 1 on was continued for a further 2 days. After bolling the culture for $10 \mathrm{~min}$ and removing the cells, $\operatorname{CoA}$ in the culture broth was asayed as deacribed in the text.

\begin{tabular}{lcc}
\hline Condition & $\begin{array}{c}\text { Con forned } \\
\text { (mg/ml) }\end{array}$ & $\begin{array}{c}\text { PH after 3 day } \\
\text { culture }\end{array}$ \\
\hline A. adenfne + CPC & 0.0 & 7.6 \\
B. Adenine + CPC & 1.2 & 6.4 \\
C. AMP & 0.3 & 6.0 \\
D. AMP + CPC & 2.9 & 6.0 \\
B. AMP + CPC & 2.1 & 6.0 \\
F. ATP + CPC & 2.5 & 6.0 \\
\hline
\end{tabular}

cursors in the presence of cetylpyridinfum chloride surfactant as shown in Table VI. The accumulation of CoA with the growing cells in the culture broth will be Investigated in detall in the following section.

\section{DISCUSSION}

The amount of CoA formed by the alrdrled cell system of Brevibacterium ammoniagenes reached 8 maximum value of $2.0 \mathrm{mg}$ per $\mathrm{ml}$ of the reaction mixture upon an addition of sultable concentration of surfactant. Furthermore, it was observed that oeveral mg of CoA per $\mathrm{ml}$ of the culture broth were accumulated during the growth in the presence of a surfactant.

As described in the preceding sectIon, the formation of CoA with yeast cell system was stimulated by cationic surfactants, but not by anionic ones. While, the stimulation for CoA formatIon with bacterial cell system was observed not only by an addition of cationic surfactant but also by that of antonic one. The effects of surfactants on metabolism of mlcroorganisms have been reported in several mlcrobial processes buch as the glutamic acid fermentation, nucletc acid-related compounds production, and so on $(73,74,76,77)$. Nara et al. (73) reported the leakage of ribose 5-phosphate and the enzymes for salvage synthesis of IMP Into the liquid medium in the presence of certain cationtc surfactant. In the case presented here, it seemed that the stimulative effect of surfactants on the formation of CoA was caused by the changes of the permeability of the substrates and the products rather than the leakage of CoA synthesizing enzymes. ATP is required as an essential energy source and a substrate for the CoA blosynthesis (14). As demonstrated above, ATP concentration was one of the most Important factors for the CoA formation in the dried cell system. While, In growing culture system, the accumulation of $C O A$ was observed by the addition of AMP. This suggests that an efficlent accumulation of $\mathrm{COA}$ in the culture broth was brought through the 
regeneration of the ATP used.

The cella grown in acetate media showed the higher activity of CoA formation than those grown in glucose media. This may be caused by the differences between the anabolic pathways of acetic actd and glucose. 


\title{
Section R.
}

\author{
An Improved Method for the Fermentative Production of Coenzyme A \\ from Pantothenic Acid, Cysteine, and 5'-AMP ${ }^{e, f)}$
}

\begin{abstract}
The cultivation of Brevibacterium ammoniagenes IFO 12071 with pantothenic actd, cystelne, and AMP gave CoA in a high yield. The organism was atabilized by repeated single colony isolations. The culture conditions optimal for the production of CoA were lnvestigated, and the yleld of $\mathrm{COA}$ in the culture broth reached more than $3 \mathrm{mg} / \mathrm{ml}$. The advantages and disadvantages of the present method were diacussed by comparing them with the original dried cell method.
\end{abstract}

\section{INTRODUCTION}

Several successful processes for the production of various 5'ribonucleotides using microorganlsms have been reported (78). Kinoohita and his coworkers (58, 59,79-81) have reported that ribotides of purines, pyrimidines, and their analoga were produced through a salvage pathway in Brevibacterium ammoniagenes ATCC 6872 and other bacterla. Ogata, Tochlkura, and their coworkers (82-85) have reported the production of varlous nucleotide coenzymes under fermentation or respiration conditions of yeasts.

These reports strongly suggest the possibility of a higher production of COA with microorganlsms. And in the previous sections, the author has demonstrated higher productions of CoA from pantothenic acid, cyateine, and ATP or AMP by dried cells of Brevibacterium ammoniagenes IFO 12071 and by dried cells of baker's yeast.

Th1s section describes an applicatton of a general and satiafactory process for nucleotide production by Kinosh1ta et al. to the production of COA.

\section{MATERLALS AND METHODS}

Microorganism. Brevibacterium ammoniagenes IFO 12071 was used.

Chemicals. CoA ( $92 \%$ pure) used as a standard was prepared by incubating pantothenic ac1d, cystelne, and ATP with dried cells of Brevibacterium ammoniagenes IPO 12071 as described In Sect1on I. Acetylphosphate was prepared by the method of Avison (42). Surfact- ants were provided by Sanyo Kasei Co., Ltd., Kyoto; Nikko Chemicals Co., Ltd., Tokyo; and Kao Soap Co., Ltd., Tokyo. other chemicals were obtained from commercial sources.

Culture methods. Forty ml of a seed culture medium contalning $0.4 \mathrm{~g}$ of glucose, $0.6 \mathrm{~g}$ of peptone, $0.12 \mathrm{~g}$ of $\mathrm{K}_{2} \mathrm{HPO}_{4}$, $0.08 \mathrm{~g}$ of $\mathrm{NaCl}$, and $0.008 \mathrm{~g}$ of $\mathrm{MgSO}_{4}$. $7 \mathrm{H}_{2} \mathrm{O}, \mathrm{pH} 7.0$, were poured into a $500 \mathrm{ml}$ shaking flask and the inoculated medlum was shaken for $24 \mathrm{hr}$ at $28^{\circ} \mathrm{C}$. Two ml of the grown seed were inoculated into $20 \mathrm{ml}$ of the fermentation medium in a $500 \mathrm{ml}$ shaking flask. The fermentation medium, which was derived from the medium of Tanaka et al. (58), contalned 2 $\mathrm{g}$ of glucose, $0.12 \mathrm{~g}$ of urea, $0.2 \mathrm{~g}$ of yeast extract, $0.4 \mathrm{~g}$ of $\mathrm{K}_{2} \mathrm{HPO}_{4}, 0.2 \mathrm{~g}$ of $\mathrm{MgSO}_{4} \cdot 7 \mathrm{H}_{2} \mathrm{O}$, and $0.04 \mathrm{~g}$ of AMP in 20 ml of delonized water. The initial pH of the medium was adjusted to 7.6. Urea was autoclaved separately. All fermentations were run at $28^{\circ} \mathrm{C}$ for 5 to 7 days on a rectprocal shaker (Satake Kagaku, 951), which was oet for 140 oscillations permin with an amplitude of $14 \mathrm{~cm}$ unless otherwise stated. To the 3 day culture, $0.04 \mathrm{~g}$ of calctum pantothenate, 0.048 of cysteine, and $0.02 \mathrm{~g}$ of cetylpyridialum chioride were added, and the cultivation was continued for a further 2 to 4 days. The cultured broth was bolled for 3 min and centrifuged. The supernatant was employed in the determination of the producta.

Analytical methods. The analytical methods employed here were the same as 
those described in section $I$.

\section{RESULTS}

Selection of an active strain from Brevibacterium ammoniagenes IFO 12071

First, the original strain IFO 12071, which produced $1-2 \mathrm{mg} / \mathrm{ml}$ of $\mathrm{CoA}$ at low frequency, was stabilized by repeated single colony selections in order to obtaln a constently active strain. The original strain was inoculated on agarplates containfing the fermentation medlum, and incubated at $28^{\circ} \mathrm{C}$ for 3 days. One hundred and twenty-five strains were derlved from the original strain, and 46 strains produced more than 2 $\mathrm{mg} / \mathrm{ml}$ of CoA. One of them was found to produce about $5 \mathrm{mg} / \mathrm{ml}$ of CoA (Table I).

TABLE I. SELECTION OF AN ACTIVE STRAIN FROM BREVIAACTERTUM AMMONIAGENES IFO 12071 BY SINGLE CELL ISOLATION

Fermentation was carried out as described In the text.

\begin{tabular}{|c|c|c|}
\hline $\begin{array}{l}\text { Product ivity } \\
\text { CoA }=g / \text { ml }^{\mathrm{a}}\end{array}$ & $\begin{array}{l}\text { Number of } \\
\text { strain }\end{array}$ & $x$ \\
\hline $5.0-3.5$ & 2 & 2 \\
\hline $3.4-3.0$ & 8 & 6 \\
\hline $2.9-2.5$ & 17 & 14 \\
\hline $2.4-2.0$ & 19 & 15 \\
\hline $1.9-1.5$ & 14 & 11 \\
\hline $1.4-1.0$ & 7 & 6 \\
\hline $0.9-0.5$ & 3 & 2 \\
\hline $0.4-0$ & 55 & 44 \\
\hline Total & 125 & 100 \\
\hline
\end{tabular}

a) COA asagys vere made for 7 day cultures.

\section{Culture conditions}

Glucose and other sugars. Figure 1 shows that the optimum level of glucose in the fermentation medium for the production of CoA was about $10-12 \%$. At lower levels of glucose, production of ATP and CoA was scarcely observed at all, though the cell growth was rapld and strong. A weak growth and no production of CoA was observed when glucose was replaced by other sugars (sucrose, fructose, mannose, maltose, and xylose).

Nitrogen sources and nutrients. Several nftrogen compounds and nutrients

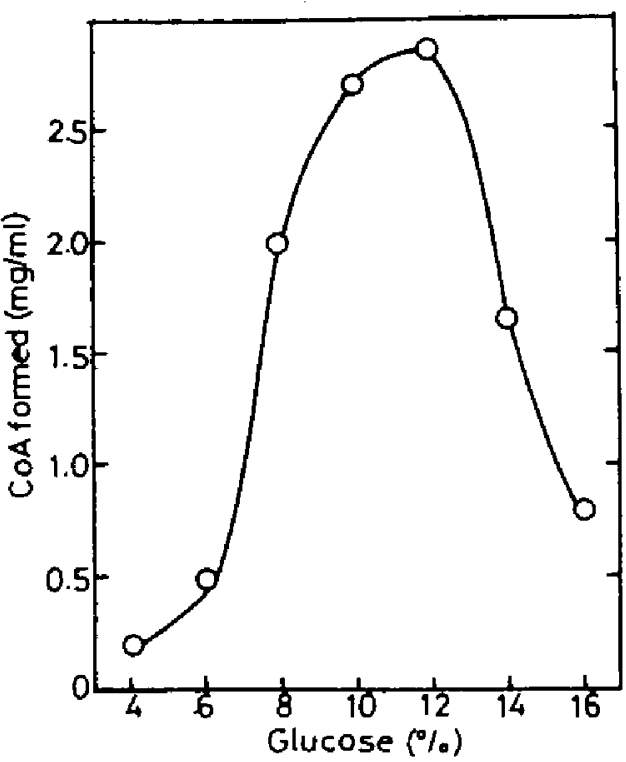

FIG. 1, Effect of Glucose Level on Production of $\operatorname{CoA}$.

Fermentation was carried out as described in the text except for glucose concentration. CoA assays were made for 6 day cultures.

listed in Table II were tested for the production of CoA. Only combinations of urea and natural nutrients gave a good production of CoA. Elther omissIon of urea or replacement of urea with other inorganic nitrogen compounds gave a decreased production of CoA, though the cell growth was rapld and strong. Combinations of urea and inorganic nitrogen compounds as listed in Table II were also Ineffective for the productIon of CoA as well as for the cell growth. For good production, a $0.6 \%$ or higher level of yeast extract was required, when the effect of the yeast extract level on the production of CoA was examined.

Inorganic phosphate and magnesium sulfate. The levels of both Inorganic phosphate and magnestum sulfate in the fermentation medium affected the production of CoA. The optimum level of inorganic phosphate was $1.5-2.0 \%$, and that of magnesium sulfate was about $1.2 \%$.

Pantothenic acid and cysteine. The amount of CoA produced increased with an increased addition of pantothenic 
TABLE II. EPFECT OF NITROCEN SOURCES AND NUTRIENTS ON PRODUCTION OF COA Fermentation wes carried out as deacribed in the text except for nitrogen and nutrient.

\begin{tabular}{|c|c|c|}
\hline Nitrogen source or nutrient $(t)$ & $\begin{array}{l}\text { CoA formed } \\
(\mathrm{mg} / \mathrm{ml}) \mathrm{a})\end{array}$ & Growthb) \\
\hline 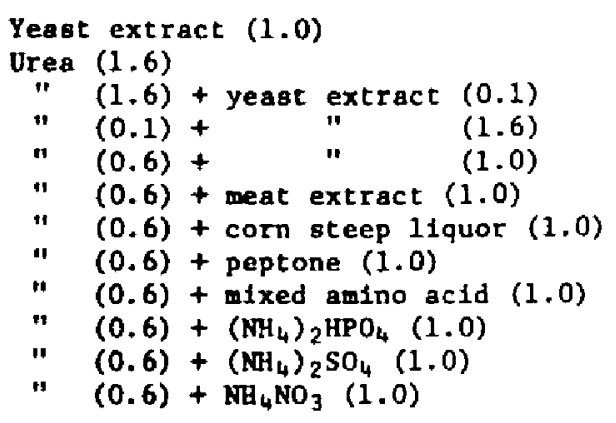 & $\begin{array}{l}0.2 \\
0.0 \\
0.0 \\
0.2 \\
2.4 \\
3.3 \\
0.1 \\
3.6 \\
1.2 \\
0.0 \\
0.0 \\
0.0\end{array}$ & $\begin{array}{l}++ \\
- \\
- \\
++ \\
++ \\
++ \\
++ \\
++ \\
++ \\
+ \\
+\end{array}$ \\
\hline
\end{tabular}

a) CoA assays were made for 5 day cultures.

b) Growth was checked for 3 day cultures: ++ , strong; + , weak; -, no growth.

acid, and reached a maxtmum level (4.8 $\mathrm{mg} / \mathrm{ml}$ ) at $2-4 \mathrm{mg} / \mathrm{ml}$ of pantothentc acid. Further addition of pantothenic acid gave a decreased production of CoA (FIg. 2). The cysteine requirement for maximum production of $\mathrm{CoA}$ was $1-3 \mathrm{mg} / \mathrm{ml}$ (F1g. 3).

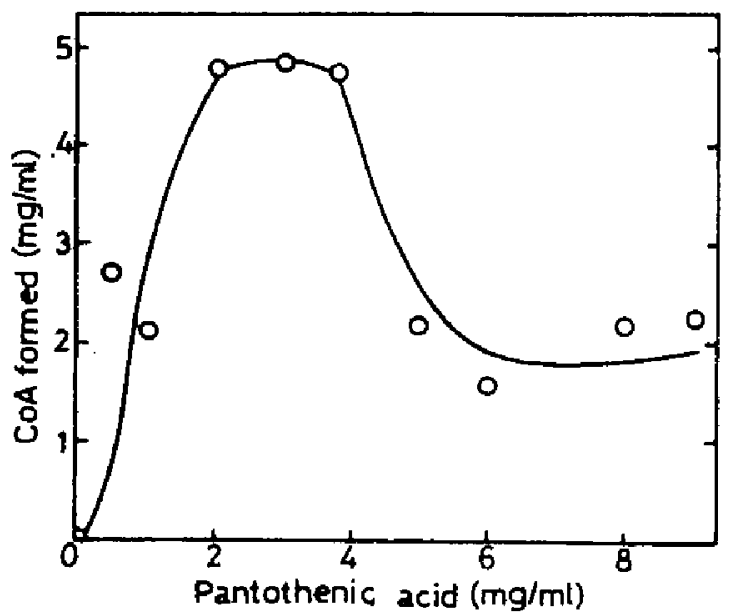

FIG. 2. Effect of Pantothenic Acld Level on Production of CoA.

Fermentation was carried out as described In the text except for calcium pantothenate concentration. CoA assays were made for 5 day cultures.

AMP and its related compounds. As to the AMP level, the production of CoA was observed over a wide concentration range of AlP (1-9 mg/ml), when yeast

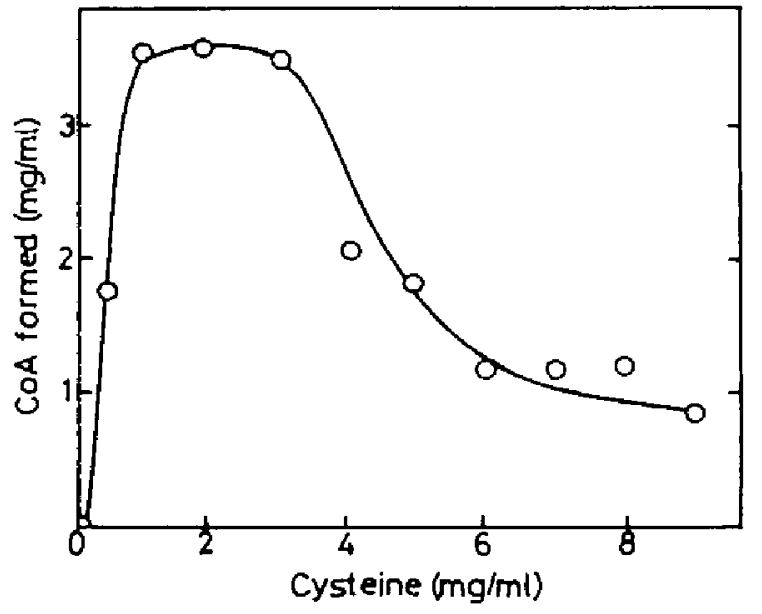

FIG. 3. Effect of Cystelne Level on Production of CoA.

Permentation was carried out as described in the text except for cysteine concentration. CoA assyas were made for 5 day cultures.

extract was used as a nutrient. On the other hand, a higher production of CoA was observed over relatively limited ranges of AMP $(2-3 \mathrm{mg} / \mathrm{ml})$, when poptone was used as a nutrient, and a maximum production of $\mathrm{COA}(5.5 \mathrm{mg} / \mathrm{ml})$ occurred at $3 \mathrm{mg} / \mathrm{ml}$ of AMP. A mixed addition of peptone and yeast extract also gave a higher production of CoA (FIg. 4).

The production of CoA with adenine or adenosine replacing AMP was examined. Elther adentine or adenosine repressed the cell growth and gave no production of CoA, when added before the culture. 


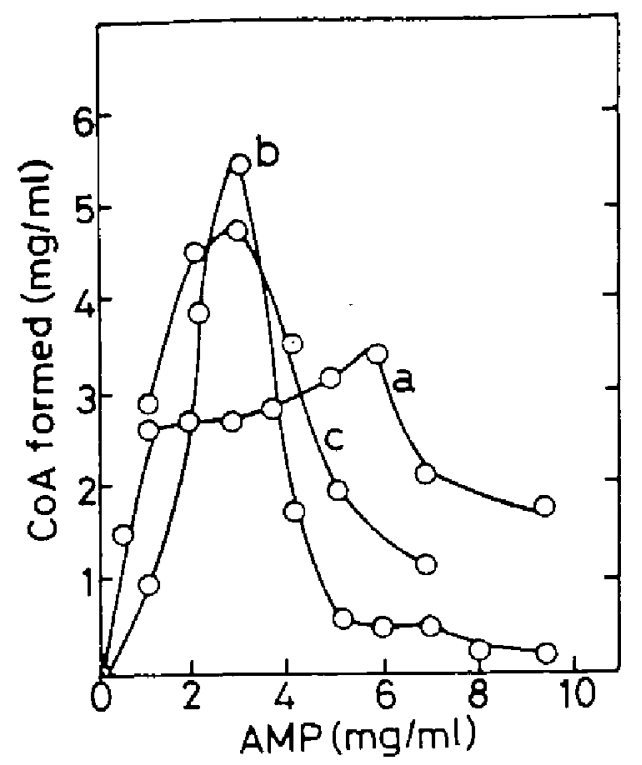

FIG. 4. Effect of AMP Level on Production of CoA.

Fermentation was carried out as described in the rexe except for AMP concentration and nutrient: $a$, yeast extract $1.0 \% ; b$, peptone $1.0 x ; c$, peptone $1.0 \%$ + yeast extract $0.3 \%$. CoA assays vere made for 5 day cultures.

TABLE III, PRODUCTION OF COA FROM ADENT NE OR ADENOSINE

Fermentation was carried out as described in the text except that AMP was replaced with aden1ne or adenosine. AMP-supplemented medium was used for the control run.

\begin{tabular}{llc}
\hline $\begin{array}{c}\text { Compound } \\
\text { added } \\
(2 \mathrm{mg} / \mathrm{ml})\end{array}$ & $\begin{array}{c}\text { Addition } \\
\text { time }\end{array}$ & $\begin{array}{c}\text { CoA formed } \\
\left.(\mathrm{mg} / \mathrm{m} 1)^{\mathrm{a}}\right)\end{array}$ \\
\hline Adenine & $\begin{array}{l}\text { before culture } \\
\text { after 3 days }\end{array}$ & 0.2 \\
Adenosine & $\begin{array}{l}\text { before culture } \\
\text { after 3 days }\end{array}$ & 0.5 \\
Control (AHP) & before culture & 1.8 \\
\hline
\end{tabular}

a) Con assays vere made for 7 day cultures.

However, additions made to 3 day cultures gave a good production of CoA (Table III).

Brown (14) reported that CTP 1s required for the coupling of 4 '-phosphopantothenic acid and cysteine in a bacterial system. In order to examine the supplementary effect of CTP, both AMP and CMP (or CTP) were added to the culture. But further increased production of CoA was not observed, though consum- ption of pantothenic acid was somewhat rapld.

Surfactants. The stimulative effect of surfactanta on the production of CoA by dried cells of baker's yeast and of Brevibacterium ammoniagenes IFO 12071 was described in the preceding sections. In this experiment, vartous surfactants were tested, and a remarkable stimulation of the production of CoA by certain surfactants belonging to the class of cationics and amphoterics was observed. One of them, Lebon 15, gave the best production of CoA (Table IV). The anionics and nonionics employed here were ineffective, though most anionics were very effective in the system using dried cells or washed cells of Brevibacterium ammoniagenes IFO 12071 (see Section III).

TABLE IV, EFFECT OF SURFACTANT ON PRODUCTION OF COA

Fermentation vas carried out as described in the text except for the surfactant.

\begin{tabular}{lr}
\hline \multicolumn{1}{c}{ Surfactant (1 $\mathrm{mg} / \mathrm{ml})$} & $\begin{array}{c}\text { CoA formed } \\
\left.(\mathrm{mg} / \mathrm{ml})^{\mathrm{a}}\right)\end{array}$ \\
\hline No addition & 0.0 \\
Cetylpyridinium chloride & 2.4 \\
Laurylpytidinium chloride & 2.9 \\
Cetyltrimethylammonium bromide & 1.4 \\
Cetylethyldimethylamonium chloride & 2.6 \\
Stearyltrimethylamorilum chloride & 2.7 \\
Cetylbenzyldimethylammonium chloride & 2.9 \\
Laurylbetalne & 2.6 \\
Lebon 15* & 4.4 \\
Sodium laurate & 0.1 \\
Potassium laurylsulfate & 0.0 \\
Sodium di-2-ethylhexylsulfosuccinate & 0.2 \\
Laurylsarcostnate & 0.8 \\
Tween 20 & 0.0 \\
Tween 80 & 0.0 \\
Span 20 & 0.0 \\
Span 40 & 0.0 \\
\hline
\end{tabular}

a) Cos assays vere made for 5 day cultures.

* Sodtum alkyldi (aminoethyl)glycine.

Aeration. The strain was cultured in a $500 \mathrm{ml}$ shaking flask with varying volumes of the fermentation medium. The stable production of CoA was observed in flasks containtng 10-60 ml of the medium (Fig. 5). When the fermentation was carried out at 120 oscillations per min and an amplitude of $7 \mathrm{~cm}$, the 
cell growth and production of CoA were greatly repressed (Table V).

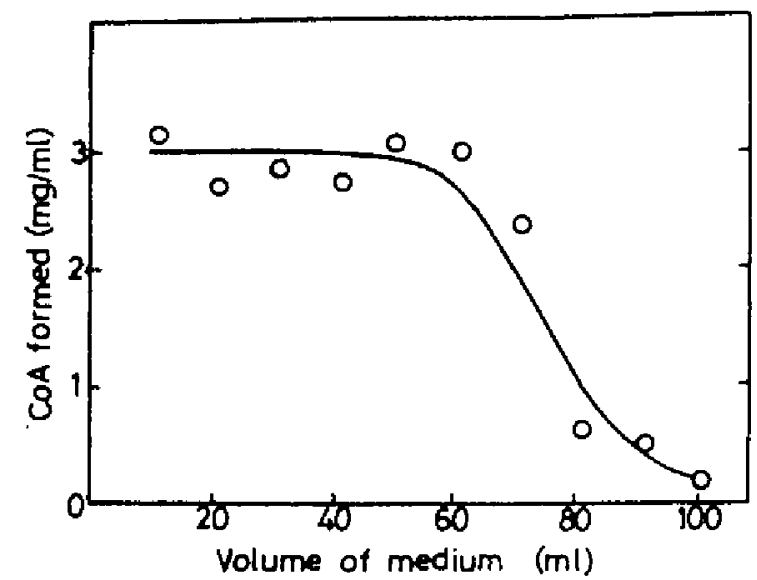

FIG. 5. Effect of Culture Volume on Production of COA.

Fermentation was carried out as described in the text except for the volume of mediun. Each seed volume was 107 . CoA assays were made for 7 day cultures.

TABLE $V$. EFFECT OF SHAKING ON PRODUCTION OF COA

Fermentation was carried out as described in the text except for conditions indicated.

\begin{tabular}{|c|c|c|c|}
\hline Shaking condit fon & $\begin{array}{l}\text { Volume } \\
\text { of } \\
\text { med } 1 \text { m } \\
\text { (ml) }\end{array}$ & $\underset{(\mathrm{mg} / \mathrm{ml})^{\mathrm{a})}}{\mathrm{CoA}}$ & $\begin{array}{c}\text { Growth } \\
(\mathrm{mg} / \mathrm{ml})\end{array}$ \\
\hline $\begin{array}{l}\text { Oectllation } 140 / \text { min } \\
\text { Amplitude } 14 \mathrm{~cm}\end{array}$ & $\begin{array}{l}20 \\
40\end{array}$ & $\begin{array}{l}2.7 \\
2.5\end{array}$ & $\begin{array}{l}25.0 \\
24.5\end{array}$ \\
\hline $\begin{array}{l}\text { Oscillation } 140 / \mathrm{min} \\
\text { Amplitude } 7 \mathrm{~cm}\end{array}$ & 20 & 0.2 & 15.5 \\
\hline $\begin{array}{l}\text { Oscillation } 120 / \mathrm{min} \\
\text { Amplitude } 7 \mathrm{~cm}\end{array}$ & 20 & 0.0 & 8.5 \\
\hline $\begin{array}{l}\text { Oscillation } 100 / \mathrm{min} \\
\text { Amplitude } 7 \mathrm{~cm}\end{array}$ & 20 & 0.0 & 7.7 \\
\hline
\end{tabular}

a) Con assays were made for 6 day cultures. b) Growth was checked for 3 day cultures.

\section{Time course of COA production}

An example of the time course of CoA production under optimum conditions is given in Fig. 6. First, phosphorylation of AMP to ATP, then consumption of pantothenic actd occurred, and finally, CoA was gradually produced. The maximum accumulation of CoA was attained on

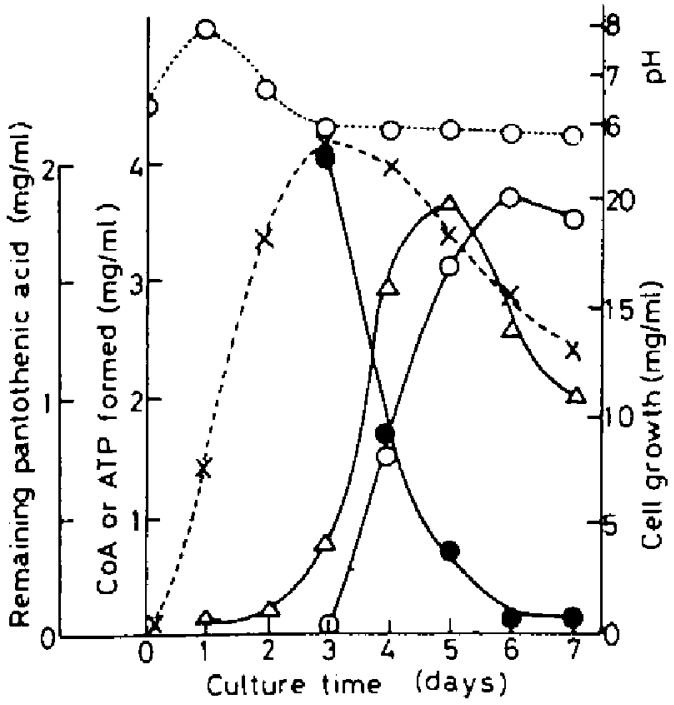

FIG, 6. Time Course for CoA Production.

Fermentation was carried out as described In the text except that the nutrients used were peptone $(0.8 \%)$, yeast extract $(0.5 \%)$, and biotin (30 ug/liter). $0-0, \mathrm{COA} ;-$ pantothenic acid; $\Delta-\Delta$. ATP; $*-*$, cell growth; $0.0, \mathrm{pH}$.

the 6 th day.

\section{DISCUSSION}

General and practical methods for the. syathesis of nucleotide derivatives from the corresponding base, nucleoside, or nucleotide, using microorganisms, fall roughly into two groups: (I) Incubation of dried cells of vartous microorganisms, especially yeasts, with a high concentration of glucose and inorganic phosphorus gives nucleoside diand triphosphates or sugar nucleotides such as ATP (34), UTP and UDP-glucose (82), GTP and GDP-mannose (83), and so on, from the corresponding nucleoside monophosphate in good ylelds. Examples of the varlations of this method are the synthesis of COA as described in the previous sections and cytidine coenzymes $(84,85)$. (II) Cultivation of microorganioms, especially bacteria, in a medium contalning high concentrations of glucose and salts also produces nucleoside mono-, $d 1-$, and triphosphates from the corresponding bases in the culture broth. Examples of this method are the synthesis of IMP (79), ATP (58), 
NAD (59), and 80 on.

As to the synthesis of CoA, Incubation of pantothenic acid, cysteine, and AMP or ATP with dried cells of baker's yest or Brevibacterium ammoniagenes IFO 12071 gave an excellent yleld of CoA as described in the previous sect1ons. This method 1s simple, rapid, and clean, though if requires the dried cell preparation as the enzyme source. The present method described here, which is an application of the method (II) to CoA production, gave a higher yield of COA under the approprlate fermentative conditions. This is considered to be very effective for the large scale production of $C O A$, though it requires somewhat tedious purification procedures when compared with the original dried cell method, as will be described in a subsequent section.

In general, fermentative production of nucleotides, as described above, are greatly affected by the cellular permeability of the microorganisms used. The removal of permeability barriers is given by drying the cells in the method (I), and by controlling the levels of trace nutrients or trace metals, or by the addition of reagents affecting cellular permeability such as surfactants, antibiotics, and so on, in the method (II). In the present experiment, the surfactant was one of the most important factors for the production of CoA. As described previously, formation of CoA with yeast cells was stimulated by the addition of certain cationic surfactants. The strong stimulation of CoA formstion by dried cells or washed cells of Brevibacterium ammoniagenes IFO 12071 was also observed by the addition of some anionic- and cationic surfactants. Nara et al. (73) reported that the enzymes relating to ribotide synthesis were excreted into the medium upon the addition of surfactant. They reported also that transphosphorylase, catalyzIng the phosphorylation of AMP to ATP, was leaked into the medium together with the above enzymes (86). These observations suggest that the COA synthesizing systems leaked out upon the additton of surfactant, coupled with the transphosphorylase system, and then, at least partly, CcA was accumulated extracellularly. 


\section{Section V. \\ A New Process for the Production of Coenzyme $A^{e, g)}$}

A new process has been deacrtbed for the preparation of CoA of high purity from the cultured broth of Brevibacterium ammoniagenes IFO 12071. The product was obtained in a ingh yield by the use of Duolite S-30, charcoal, and Dowex $1 \times 2$, and Identifled chemically and enzymatically. The method is simple, rapid, and compact, requires no speclal equipment, and has been shown to be adaptable for preparing large amounts of highly pure CoA.

\section{INTRODUCT ION}

The author has previously described the 1solation of CoA in a high yleld from a reaction mixture of dried cells of Brevibacterium ammonagenes IFO 12071 by the use of charcoal and DEAE-cellulose (Bee Section I). Further, it was found that the organism accumulated 2$5.5 \mathrm{mg} / \mathrm{ml}$ of CoA in the culture broth (see Section III and IV).

The present section deals with the Isolation and identification of CoA wth the objective of large acale production.

\section{EXPERIMENTAL AND RESULTS}

\section{Materials}

The microorgan1sm used was Brevibacterium anmoniagenes IFO 12071. DEAEcellulose ( $0.9 \mathrm{meq} / \mathrm{g}$ ) was provided from Green Crose Corporation, Osaka. Phosphotransacetylase from Clostridiun $k l u-$ yverl was purchased from Boehringer, Mannhetm. Alkaline phosphatage from calf intestinal mucosa and phosphodfesterase from Crotalus adamanteus were purchased from Sigma Chemtcal Co., St. Loula. Other materlals and chemicals were obtained from commercial sources.

\section{Analytical methods}

CoA was assayed by the phosphotransacetylase method of Stadtman et al. (43) using the enzyme of Escherichia coli Crookes AKJ 0001, and also by the method of Bergmeyer et al. (44) for the characterization of 1solated products. Total pantothenate was measired by the method of Novell1 (47). Adenine content was determined by ultravtolet abgorption in
$0.1 \mathrm{M} \mathrm{HCl}$ using $E_{260}-15000$ as the standard value. Phosphorus was measured by the method of Allen (87) and sulfhydryl by the method of Ellman (49). Paper chromatography was carried out by the ascending technique on Toyo Rosht No.53 paper. The solvent systems used were $I$, isobutyric actd- $0.5 \mathrm{~N}$ ammonium hydroxide-0.1 M EDTA (100:60:1.6); II, ethanol-1. M ammontum acetate, $\mathrm{pH} 7.5$ (5:2). Paper electrophoresis was carrled out on Toyo Rosh1 No.53 paper 1mpregnated with $0.2 \mathrm{M}$ acetate buffer, $\mathrm{pH}$ 3.5 , at $35 \mathrm{~mA} / 15 \mathrm{~cm}(4 \mathrm{KV})$ for $30 \mathrm{~min}$. Adenine-contalning compounds were located with a UV-lamp. Phosphorus-containing compounds were located with Hanes and Isherwood spray (50) followed by ultraviolet irradtation; sulfhydryl and disulfide compounds were detected with Toennies and Kolb spray (51).

\section{Process}

1) Cuitivation. Brevibacterium ammoniagenes IFO 12071 was cultivated aeroblcally for 5 days at $28^{\circ} \mathrm{C}$. The detalls of cultivation have been described in the preceding section. The culture filtrate (about $1000 \mathrm{ml}$ ) contalned about $2.5 \mathrm{~g}$ of $\mathrm{CoA}$ as the disulfide (or mixed disulfides) and some intermediates of CoA blosynthes1s, such as $4^{\prime}$-phosphopantothenic acid and $4^{\prime}$-phosphopantetheine (disulfide or mixed disulfide), in high concentrations.

2) Purification. Inttially the usual blochemical laboratory method was employed. The culture filtrate (50 ml) was applied to a column of charcoal (4 $x 4 \mathrm{~cm})$, and the substances adsorbed were eluted with $40 \%$ acetone containing 
$0.028 \%$ ammon1a. CoA-containing fractlong were well separated from brown materlala (Bee Fig. 1, (B)). Appropriate fractions containing $C O A$ were combined, concentrated to a small volume (50 ml) under reduced pressure, and 2mercaptoethanol $(17 \mathrm{ml})$ was added. The mixture was left for 24 hr at $10^{\circ} \mathrm{C}$, and then it was applied to a colmm of DEAEcellulose (chloride form, $3 \times 18 \mathrm{~cm}$ ). Elution with $0.02 \mathrm{M} \mathrm{LiCl}$ in $0.003 \mathrm{M} \mathrm{HCl}$ (1000 ml) removed AMP, 4'-phosphopantothenlc actd, 4'-phosphopantethelne, and ADP. Then further elution was carried out by a $4000 \mathrm{ml}$ 11near salt gradient $(0.03-0.1 \mathrm{M} \mathrm{LiCl}$ in $0.003 \mathrm{M} \mathrm{HCl})$. For both the initial and gradient elutions 2-mercaptoethanol was present in the eluting solution at a concentration of 0.17 . Two major ultraviolet-absorbing peaks were separated. The first peak (COASH) was adjusted to $\mathrm{pH} 4.5$ with $\mathrm{L} 1 \mathrm{OH}$, and evaporated to dryness. The residue was dissolved in a small volume of methanol and the lithium salt of CoAsH was precipitated by the addition of 20 volumes of acetone. The salt was collected, and washed repeatedly with methanol-acetone (1:9). After drying over $\mathrm{P}_{2} \mathrm{O}_{5}$ in vacuo, the trilithium salt of CoASH was obtained as a fine white powder $(40 \mathrm{mg})$. The product was homogeneous with respect to ultraviolet absorption, sulfhydryl, and phosphorus, when chromatographed on paper. Venom phosphodiesterase digestion gave spots identical with $3^{\prime}, 5^{\prime}-\mathrm{ADP}$ and $4^{\prime}$-phosphopantetheine.* AnaI. Calcd. for $\mathrm{C}_{21} \mathrm{H}_{33^{-}}$ $\mathrm{O}_{16} \mathrm{~N}_{7} \mathrm{P}_{3} \mathrm{SLI}_{3} \cdot 8 \mathrm{H}_{2} \mathrm{O}: \mathrm{C}, 27.13 ; \mathrm{H}, 5.37 ; \mathrm{N}$, $10.54 \%$. Adenosine : phosphorus : sulfhydryl : pantothenic actd, 1:3:1:1.

Found: $\mathrm{C}, 27.01$; H, 5.01; N,10.30\%. Adenosine : phosphorus : sulfhydryl : pantothenic ac1d, 1:3.03:1.00:0.99. UV $\lambda \max$ In $0.1 \mathrm{M} \mathrm{HCl}, 259 \mathrm{~nm}$; UV $\lambda \max$ in $0.1 \mathrm{M}$ $\mathrm{NaOH}, 260 \mathrm{~nm}$. Assayed by the phosphotransacetylase method of Bergmeyer et al. (44), the product showed a $101 \%$ activity on the basis of 1ts adenosine content.

* This compound was prepared by the method as described in a subsequent section.
The second peak (ATP) was worked up as described above to give a lithium salt of ATP $(71.5 \mathrm{mg})$. The product was homogeneous w1th respect to ultraviolet absorption and phosphorus when chromatographed on paper. The molar ratio of adenosine: phosphorus was $1: 3.10$ (Required, 1:3). UV $\lambda \max$ in $0.1 \mathrm{M} \mathrm{HCl}, 259$ nim; iv $\lambda \max$ in $0.1 \mathrm{M} \mathrm{NaOB}, 260 \mathrm{~mm}$.

Next, a large scale purification was carrled out with the objective of appllcation to tadustrial production. The culture filtrate $(1000 \mathrm{ml})$ was passed

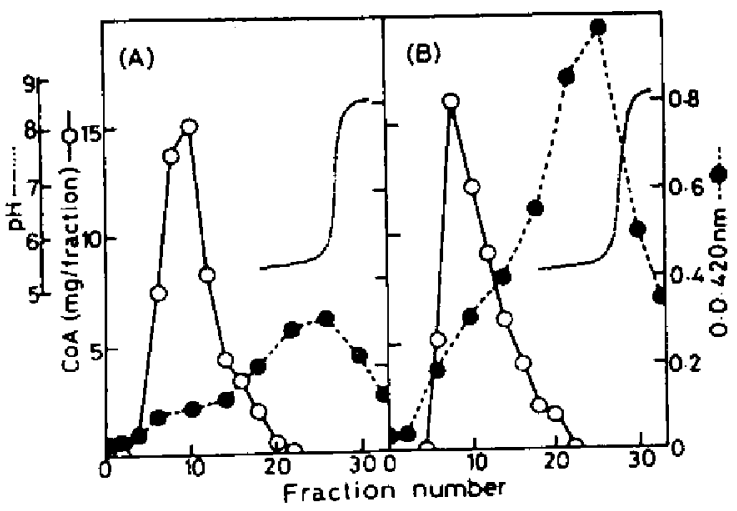

FIG. 1. Separation of COA and Brown Materials on a Charcoal Colum.

Fifty ml of the culture filcrate were applied on a column $(4 \times 4 \mathrm{~cm})$ of charcoal after passIng through a column $(2 \times 5 \mathrm{~cm})$ of Duolite S30 (A). (B) is a control run (wthout Duolite S-30). Each fraction contalns 10 ml of eluate.

through a column of Duolite $5-30$ (3 x $20 \mathrm{~cm})$ to remove brown mater 1 als, and the column was washed with water (100 $\mathrm{ml})$. The solution passing through the column was directly applied to a column of charcoal $(5.5 \times 30 \mathrm{~cm})$, and the substances adsorbed were eluted with $40 \%$ acetone containing $0.028 \%$ amonia (A result of a small scale experiment to know the effect of Duolite $S-30$ and charcoal on the removal of brown materials is shown in Fig. 1.). The eluted solution containing acetone was directly adsorbed to a column of Dowex $1 \times 2$ (chloride form, $5.5 \times 42.5 \mathrm{~cm}$ ). The products were eluted from the column with solutions of LICl in HCl. An example of the elution pattern is shown in Fig. 2. In each case, appropriate 


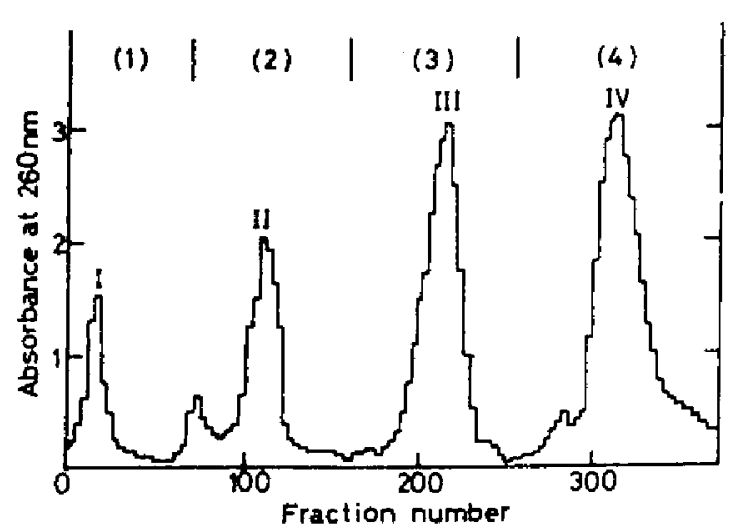

FIG. 2. A Typical Elution Pattern of Nucleotides in Culture Broth from a Dowex $1 \times 2$ Colum.

Nucleotides vere eluted from the colum (chloride form, $2.5 \times 25 \mathrm{~cm}$ ) with $0.01 \mathrm{M} \mathrm{HCl}$

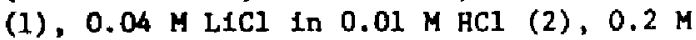
LiCl in $0.01 \mathrm{M} \mathrm{HCl} \mathrm{(3),} \mathrm{and} 0.4 \mathrm{M} \mathrm{LiCl}$ in 0.01 M HCl (4). Each fraction contalns $10 \mathrm{ml}$ of eluate. Peak I, AMP; Peak II, ADP; Peak III, ATP; Peak IV, CoASSCoA.

fractlong were comblned, adjusted to pH 4.5 with L1OH, then concentrated to a small volume, and the lithium salt was 18olated in the usual way. Ylelds were as follows: AMP, $127 \mathrm{mg}$ (Found: ratio of adenosine : phosphorus, 1:1.05; Required: 1:1). ADP, $604 \mathrm{mg}$ (Found: retio of adenosine : phosphorus, 1:2.15; Required: 1:2). ATP, $1212 \mathrm{mg}$ (Found: ratto of adenosine : phosphorus, 1:3.11; Required: 1:3). COASSCOA, $1007 \mathrm{mg}$ (Found: ratio of adenosine : phosphorus: pantothenlc actd, 1:3.05:0.90; Required: $1: 3: 1)$. This disulfide contalned a trace of a contaminating ultraviolet-absorblng compound ( $R f 0.19$ in solvent I), when chromatographed on paper. Assayed by the phosphotransacetylase method of Stadtman et al. (43) against purified CoA ( 927 by welght) standard, it showed 83-877 activity.

For the purpose of reduction, the above disulfide ( $250 \mathrm{mg}$ ) was dissolved In water (5 ml) and 2-mercaptoethanol (5 ml) was added. The mixture was left for $24 \mathrm{hr}$ at $10^{\circ} \mathrm{C}$, adjusted to $\mathrm{pH} 4.5$ wth $\mathrm{L} 1 \mathrm{OH}$, and worked up as described above to glve a lithium salc (222 mg, Found: ratio of adenosine : phosphorus : sulfhydryl : pantothenic ac1d, 1:3.07: $0.88: 0.93$; Required: $1: 3: 1: 1$ ), which
TABLE I. PAPER CHROMATOGRAPHY AND PAPER ELECTROPHORESIS

\begin{tabular}{lccc}
\hline \multirow{2}{*}{ Compound } & \multicolumn{2}{c}{ Rf } & \multirow{2}{*}{ Electrophoresis* } \\
\cline { 2 - 3 } & I & II & \\
\hline CoASH & 0.57 & 0.16 & 18.5 \\
COASSCOA & 0.38 & 0.01 & 19.5 \\
AMP & 0.55 & 0.13 & 9.7 \\
ADP & 0.44 & 0.04 & 16.5 \\
ATP & 0.33 & 0.02 & 21.0 \\
\hline
\end{tabular}

* Migration towards the anode is given in $\mathrm{cm}$.

was chromatographically shown to contaln only CoASH and a little of the disulfide. Assayed by the phosphotransacetylase method of Bergmeyer et al. (44), it showed an $84 \%$ activity on the basis of Its adenosine content.

A further purifled sample was obtained as the thiol form from the above disulflde by reduction with 2-mercaptoethanol followed by Dowex $1 \times 2$ (chloIlde form) column chromatography. The CoASH was eluted with $0.2 \mathrm{M}$ LiCl in $0.01 \mathrm{M} \mathrm{HCl}$ containing $0.1 \%$ 2-mercaptoethanol. The product was homogeneous wth respect to ultraviolet absorption, phosphorus, and sulfhydryl on paper chromatogram. Assayed by the phosphotransacetylase method of Bergmeyer et al. (44), it now showed a $97 \%$ activity on the basis of 1 ts adenosine content.

\section{DISCUSSION}

CoA has been prepared by extraction from mlcroorganisms $(20,21,25-27,29)$ and by chemical synthesis $(28,30-32)$. However, these methods are not pract1cal because of their lower yleld or their intricacy. A new improved process with a microorgantsm has now been developed. Incubation of pantothenic ac1d, cystelne, and ATP with the dried cells of Brevibacterium ammonigenes IFO 12071 gave CoA in a high yield. The product was 1solated as the thiol form at a high level of purity by the use of charcoal and DEAE-cellulose (see Section I) . Further, cultivation of the organlom with pantothenic acid, cysteine, AMP, and a surfactant gave a higher accumulation of CoA (2-5.5 $\mathrm{mg} / \mathrm{ml})$ in the culture broth (gee Section IV). 
The product in the culture broth was purified by the use of Duolite $S-30$, charcoa1, and Dowex $1 \times 2$, and isolated as the 1ithium salt in good yield.

As described in Section $I$, the product was directly isolated as the thiol form from the reartion mixture without prior separation of ATP, Bince the ATP in the reaction mixture was completely consumed for the CoA formation. On the other hand, in the present process it was necessary to remove ATP in order to obtain the product in hIgh yteld and high purity. Isolation of the product directly as the disulfide form rather than the thiol form brought a complete separation of ATP, and led to a considerably improved yield. The disulfide was readily converted to the thiol form by treatment with 2-mercaptoethanol. A further Improved yield of CoA might be attained by recovering the mixed disulfides of COA which might be present in the culture broth.

The present process is simple, rapid, and compact, and requires no spectal equipment. From a practical point of view, it possesses considerable advantages over any other microblal process previously reported $(20,21,25-27,29)$ in that the product can be purifled in a higher yleld with a compact plant, without complex purification procedures. Th1s not only speeds up purification and isolation but also gives a highly purifled product. Therefore, the present process would be sultable for industrial production.

A further practical polnt is that AlP added as a precursor for CoA formation, can be recovered as ATP or ADP and the tsolation of some intermediates of CoA blosynthesis such as 4'-phosphopantothentc acid and $4^{\prime}$-phosphopantetheine is possible if necessary. In a similar process, these intermediates were obtained in higher yields, which will be described in a subsequent sect1on. 
Section VI.

\title{
Microbial Synthesis of Intermediates of Coenzyme A Biosynthesis ${ }^{e, h)}$
}

\begin{abstract}
Greater production of 4'-phosphopantothenic acid and 4'-phosphopentetheine by a microorganlsm were described. The incubation of pantothenic acld and ATP with washed cells of Brevibacterium ammoniagenes IFO 12071 gave 4'-phosphopantothenlc acid in a high yleld. Cultivation of the organisw with pantothenic acld and AMP also gave 4'-phosphopantothentc actd in a high yleld. In a similar fashon, 4 '-phosphopantetheine was readily obtalned in a good yield. The producta were identified chemically and enzymatically.
\end{abstract}

\section{INTRODUCTION}

Phosphorylation of pantothenfc acid was firat found by Plerpolnt et al. (75), and then Brown (14) demonstrated that $4^{t}$-phosphopantothenlc acld is the first metabolite in the blosynthesis of CoA from pantothenic acid. Brown (14) also demonstrated that $4^{\prime}$-phosphopantetheine, the third intermediate from pantothenic acid to CoA, is synthesized through a coupling of $4^{\prime}$-phosphopantothenic actd and cystelne, followed by decarboxylation of the cysteine motety. As a proteln-bound prosthet1c group, $4^{\prime}$-phoophopantetheine plays a central role in the biosynthesis of fatty acids (88) and of peptides such as gramic1din $S$ and tyrocidfne (89). These 1mportant compounds (or coenzymes) have been exclusively prepared by complex chemical syntheses $(28,90-93)$.

In the previous sections, the author has demonstrated that $\mathrm{COA}$ and some of 1ts biosynthetic intermediates can be synthesized in higher ylelds by a microbial process. The optimum conditions for CoA production and the purification and 1solation of the products were also described.

Th1s section deals with a new preparative method for the intermediates of COA bfosynthesis.

\section{MATERIALS AND METHODS}

Chemicals. ATP was kindly given by Kyowa Hakko Kogyo Co., Ltd., Tokyo. Authentic samples of 4'-phosphopantothenic acid, 4'-phosphopantothenoylcys- teine, and 4'-phosphopantetheine (d1sulflde form) used for paper chromatography and paper electrophoresis were the kind gifts of Dr. M. Shimlzu, Da1ich1 Selyaku Co., Ltd., Tokyo. DEAEcellulose $(0.9 \mathrm{meq} / \mathrm{g})$ was provided by Green Cross Corporation, Osaka. AlkaIne phosphatase from calf intestinal mucosa and phosphodlesterase from Crotalus adamanteus were obtalned from Sigma Chemical Co., St. Louls. Other chemicals were obtained from comercial sources.

Microorganism and cultivation. Brevibacterium anmoniagenes IFo 12071 was used. The medla for the microorganism and cultivation techniques were the same as those described in the previous sections.

Analytical methods. Pantothenic acid was measured microbiologically using Saccharomyces carlsbergensis ATCC 9080 (46) and Lactobacillus plantarum ATCC 8014 (45), 4'-Phosphopantothenic actd was measured by following the disappearance of pantothenic actd in the reaction mixture or culture broth. This was checked by measuring the recovery of pantothenic acid after digestIon with alkaline phosphatase. CoA was measured by the phosphotransacetylase method of Stadtman et al. (43) using the enzyme of Escherichia coli Crookes AKU 0001 as described in Section I. Total pantothenate was measured by the method of Novell1 (47). The amount of the intermediates of CoA biosynthesis (4'-phosphopantothenoylcysteine, 4'- 
phosphopantethe1ne, and $3^{\prime}$-dephosphoCaA) or 4'-phosphopantethelne was calculated by subtracting pantothenic acid, $4^{\prime}$-phosphopantothenic acid, and COA from total pantothenate. In some cases 4 '-phosphopantethe1ne was also measured a pantetheine with Lactobacillus bulgaricus Bl after digesting the sample with alkaline phosphatase (94). Lactobacillus bulgaricus Bl was a klnd $\mathrm{g} 1 \mathrm{ft}$ of Dr. M. Shimizu, Dafichi Seiyaku Co., Ltd., Tokyo. Other assays were the same as those described in section $I$.

\section{RESURTS}

Formation of the intermediates of COA biosynthesis

In order to investigate whether the intermediates of COA blosynthesis are formed from pantothenic acid or $4^{\prime}$-phosphopantothenic acid, several reaction systems were tested as shown in Table $I$. In the complete reaction mixture, CoA

\section{TABLE I. PORMATION OF INTERMEDIATES OF COA BIOSFNTHESIS}

The complete reaction mixture contalned, in $1 \mathrm{ml} 2$ waoles of godium pantothenate, 4 umoles of cyoteine, 10 , nowles of ATP, 10 , moles of $\mathrm{MgSO}_{4}, 150$ umoles of potassium phosphate buffer, $\mathrm{pH} 6.5,1 \mathrm{mg}$ of sodium laurylaulfate, and $100 \mathrm{mg}$ of dried cells of Brevibactorium amoniagenes. The reactions were carried out at $37^{\circ} \mathrm{C}$ for $6 \mathrm{hr}$, and teralnated by 1maersing the tube in bolling water for $5 \mathrm{~min}$. After adding $3 \mathrm{ml}$ of water, cells vere removed by centrifugation. The superatiant was employed 1n the determination of the products.

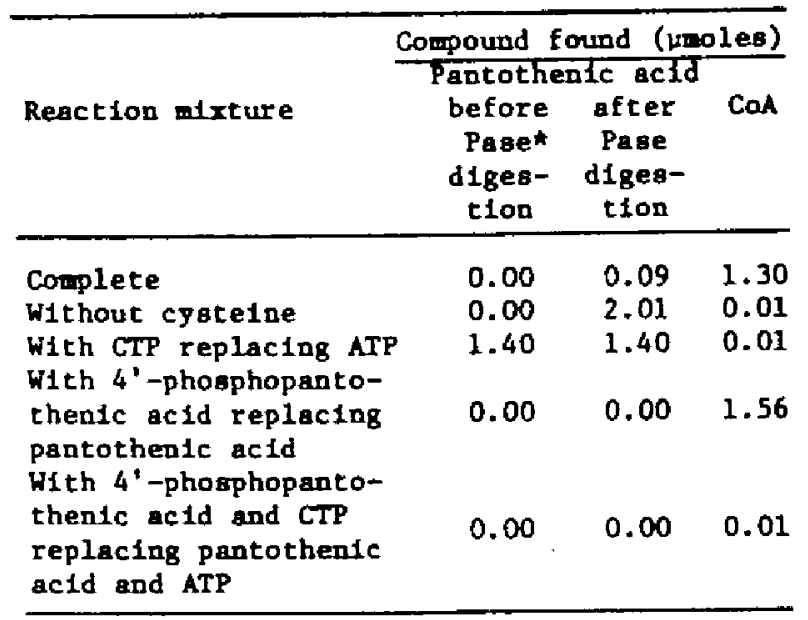

- Page: alkaline phosphatase. was formed, as has been already polnted out in the previous sections. When cystelne was omicted from the complete reaction mixture, pantothenic acid completely disappeared, wh thout the formation of CoA. It was completely recovered by treatment with alkaline phosphatase, suggesting the presence of the phosphorylated form of pantothenlc acid in the reaction mixture. When pantothenlc acld and ATP were respectively replaced by $4^{\prime}$-phosphopantothenic acid and CTP, 4'-phosphopantothenic acid disappeared without any detectable formation of CoA. On the paper chromatogram a oulfhydryl-containing opot, different from $\mathrm{COA}$ and cyateine, was detected at $R f 0.65$ using a solvent of $n$-butanol-acetic acid-water $(5: 2: 3$, by vol.). It was recovered as pantothenic acid by digestion with a mixture of alkaline phosphatase and hog kidney amidase (47), suggesting the presence of a conjugated form of pantothenic acid and cysteine in the reaction mixture.

Isolation and identification of the intermediates of COA biosynthesis

i) 4'-Phosphopantothenic acid. a) The reaction mlxture (340 ml) containIng 3.4 moles of sodium pantothenate,

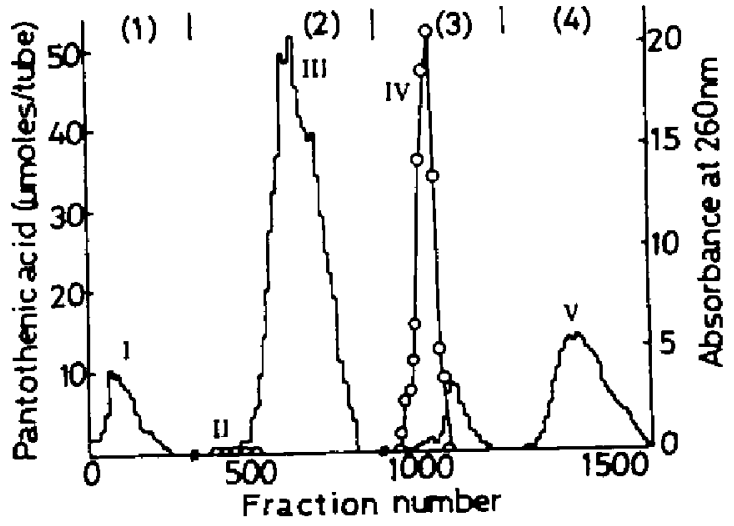

FIG. 1. Chromatography of the Products in the Reaction Mixture on a Dowex $1 \times 2$ Colum.

Compounds were eluted wth water (1), 0.007 $\mathrm{M} \mathrm{HCl} \mathrm{(2),} 0.01 \mathrm{M} \mathrm{LICl}$ in $0.01 \mathrm{M} \mathrm{HCl} \mathrm{(3),} \mathrm{and}$ $0.03 \mathrm{M} \mathrm{LiCl}$ in $0.01 \mathrm{M} \mathrm{HCl}$ (4). Each fraction contains 20 ml of eluate. Peak $I$, adenine and adenosine; Peak II, free pantothenlc acid; Peak III, AMP; Peak IV, 4'-phosphopantothenic ac1d; Peak V, ADP. 
5.1 moles of ATP, 3.4 moles of $\mathrm{MgSO}_{4}$, 34 moles of potassium phosphate buffer, $\mathrm{pH} 6.0,680 \mathrm{mg}$ of sodium laurylsulfate, and washed cells of Brevibacterium anmoniagenes $(20.48)$ was incubated for 8 hr at $37^{\circ} \mathrm{C}$. Then, the mixture was immersed for 10 min in a bolling water bath and the cella were removed by centrifugation. The supernatant was diluted to $1000 \mathrm{ml}$ with water and applied to a column of Dowex $1 \times 2$ (chloride form, $4.2 \times 40 \mathrm{~cm}$ ). The elution was carrled out as shown in F1g. 1. Elution with $0.01 \mathrm{M} \mathrm{LiCl}$ in $0.01 \mathrm{M}$ HCI gave a peak of phosphorylated pantothenic acid. Appropriate fractions were comblned, adfusted to $\mathrm{pH} 4.5$ wtth $\mathrm{LIOH}$, and evaporated under reduced pressure below $40^{\circ} \mathrm{C}$. The floal residue was disaolved In a small volume of methanol and the 11thfum salt was precipitated by the addition of 20 volumes of acetone. The salt was collected, washed repeatedly with methanol-acetone ( $1: 10$, by vol.), and dried over $\mathrm{P}_{2} \mathrm{O}_{5}$ in vacuo (yield, $608 \mathrm{mg}$; purity, based on pantothenic ac1d content, 84-88\%). For the purpose of further purification, a portion of the above I1thium salt ( $60 \mathrm{mg}$ ) was dissolved in water $(10 \mathrm{~m} 1)$ and applied to a colum of DEAE-cellulose (chlor1de form, $2 \times 30 \mathrm{~cm}$ ). Elution was carried out by a $1100 \mathrm{ml}$ linear salt gradient (0-0.05 M L1C1 in $0.003 \mathrm{M} \mathrm{HC1})$. Appropriate fractions were combined, and passed through a column of Amberlite IR-120 ( $\mathrm{H}^{+}$form). The eluate and washInga were neutrallzed with $\mathrm{Ba}(\mathrm{OH})_{2}$ and evaporated to dryness. The residue was dissolved in a small volume of methanol, clarified, and poured into 20 volumes of acetone to give a white precipitate. Th1s was collected, washed, and then dried (yleld, $34 \mathrm{mg}$ ). The product was homogeneous with reapect to phosphorus and pantothenic acid on paper chromatogram. Phosphatase digestion gave spots identical with inorgan1c phosphate and pantothenic acid. It was partially active 1n enhancing the growth of Saccharomyces carlsbergensis ATCC 9080 and Lactobacillus plantarum ATCC 8014 at higher levels and became fully active after phosphatase digestion. IR vmax
TABLE II. PAPER CHROMATOGRAPHY AND PAPER ELECTROPHORES IS

Aocending paper chromatography was performed on Toyo Rosh1 No. 53 paper using solvent $I$, n-butanol-acet1c acid-water ( $5: 2: 3$, by vol.); solvent II, lsobutyrlc acid-0.5 $\mathrm{N}$ amonlum hydrox1de-0.1 M EDTA (100:60:1.6, by vol.).

Paper electrophoresis was perforned on Toyo Roght No. 53 paper for $30 \mathrm{mln}$ (A), or 50 thin (B) at $30 \mathrm{~mA} / 15 \mathrm{~cm}(4 \mathrm{kV})$ using $A, 0.05 \mathrm{M}$ acetate buffer, $\mathrm{pH} 3.5 ; \mathrm{B}, 0.05 \mathrm{M}$ borate buf fer, $\mathrm{pH}$ 9.4. Migration towards the anode is given in $\mathrm{cm}$.

\begin{tabular}{|c|c|c|c|c|}
\hline \multirow[b]{2}{*}{ Compound } & \multicolumn{2}{|c|}{$R F$} & \multicolumn{2}{|c|}{ Migration } \\
\hline & I & II & $\bar{A}$ & B \\
\hline $\begin{array}{l}\text { 4'-Phosphopantothenic } \\
\text { acid }\end{array}$ & 0.59 & 0.53 & 12.0 & 22.3 \\
\hline $\begin{array}{l}4^{\prime} \text {-Phosphopantethe Ine } \\
\text { (thlol form) }\end{array}$ & 0.65 & 0.66 & 4.3 & 15.5 \\
\hline $\begin{array}{l}4^{\prime} \text {-Phosphopantethe ine } \\
\text { (disulfide form) }\end{array}$ & 0.40 & $-\star$ & 9.6 & 14.4 \\
\hline $\begin{array}{l}\text { Pantothentc acid } \\
\text { CoA }\end{array}$ & $\begin{array}{l}0.79 \\
0.24\end{array}$ & $\begin{array}{l}0.73 \\
0.57\end{array}$ & $\overline{13} .5$ & $\overline{16.1}$ \\
\hline
\end{tabular}

* not tested.

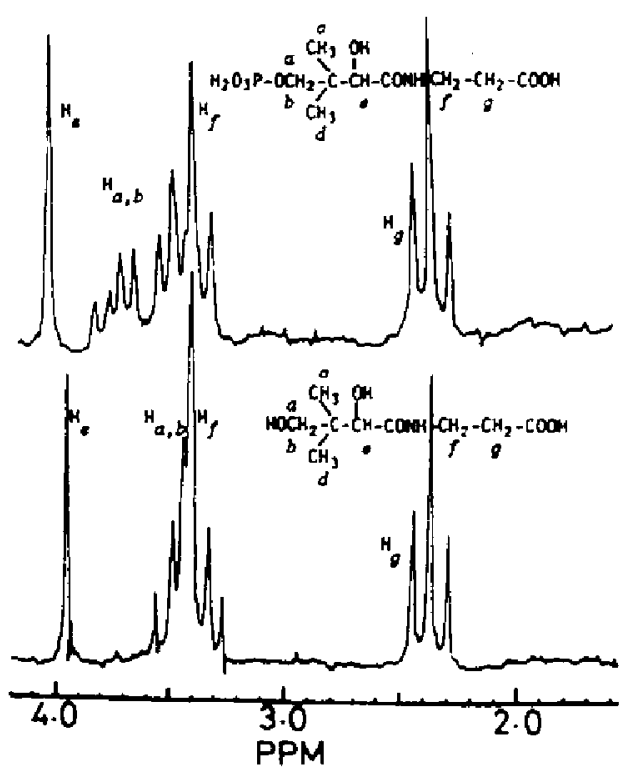

FIG. 2. Comparative NMR Spectra of 4'-Phosphopantothenic Acid and Pantathenic Acld.

MIR spectra were measured on a Hitachl Perkin-Elmer R-22 spectrometer at $90 \mathrm{MHz}$ in $\mathrm{D}_{2} \mathrm{O}$ wth DSS as the internal standard. Top, $4^{1}-$ phosphopantothenic acid; bottom, pantothenic actd.

In $\mathrm{KBr}$ pellet, $3300,2955,2880,1648,1567$, $1410,1365,1315,1260,1120,1085,977,805$ $\mathrm{cm}^{-1}$. The NMR spectrum of the 11thium 
salt ( $84-88 \%$ pure) is shown in F18. 2 . The splitting pattern of the sample 18 consistent with that of pantothenic acid except that the signals of the $4^{\prime}-$ C-protong are shifted to a lower field than those of pantothenic acld and resplitted by coupling with phosphorus. Anal. Calcd. for $\mathrm{C}_{9} \mathrm{H}_{15} \mathrm{O}_{8} \mathrm{NPBa}_{1}, 5 \cdot 3 \mathrm{H}_{2} \mathrm{O}$ : $\mathrm{C}, 19.43 ; \mathrm{H}, 3.80 ; \mathrm{N}, 2.52 \%$. Phosphorus : pantothen $1 \mathrm{c}$ acld, $1: 1$. Found: $\mathrm{C}, 19.79$; H, 3.52; N,2.48z Phosphorus : pantothenlc acid, $1: 0.97$.

b) Brevibacterium amuroniagenes was cultivated aerobically at $28^{\circ} \mathrm{C}$ in a medium composed of $10 \mathrm{~g}$ of glucose, $1 \mathrm{~g}$ of peptone, $2 \mathrm{~g}$ of $\mathrm{K}_{2} \mathrm{HPO}_{4}$, $1 \mathrm{~g}$ of $\mathrm{MgSO}_{4}$. $7 \mathrm{H}_{2} \mathrm{O}, 0.6 \mathrm{~g}$ of urea, $0.2 \mathrm{~g}$ of AMP, and $100 \mathrm{ml}$ of water, $\mathrm{pH} 7.6$. After 3 days of cultivation, $0.2 \mathrm{~g}$ of calcium pantothenate and $0.1 \mathrm{~g}$ of cetylpyridinium chloride were added, then the cultivatIon was continued for a further 2 days. The details of cultivation were described in section IV. The cultured broth (60 $\mathrm{mI})$, containtng about $150 \mathrm{mg}$ of phosphorylated pantothentc acid, was bolled for $3 \mathrm{~min}$ and centrifuged. The supernatant, after belng treated with charcoal as described in Section $I$, was applied to a column of Dowex $1 \times 2$ (chloride form, $2.5 \times 25 \mathrm{~cm}$ ). Elutions with $0.01 \mathrm{M} \mathrm{LiCl}$ in $0.01 \mathrm{M} \mathrm{HCl}, 0.03 \mathrm{M}$ LICl in $0.01 \mathrm{M} \mathrm{HCl}$, and $0.2 \mathrm{M}$ of L1Cl In $0.01 \mathrm{M} \mathrm{HCl}$ gave phosphorylated pantothenic acld, ADP, and ATP, respective1y. Each fraction was worked up as described above to give the lithium salt of the product. Finally, the lithlum salt of $4^{\prime}$-phosphopantothenlc acid was obtalned as a yellowlsh white powder (yleld, $103 \mathrm{mg}$; purity, based on pantothenic acid content, 81-85\%). Yields of ADP and ATP as by-products were 60 $\mathrm{mg}$ and $102 \mathrm{mg}$. The lithium salt of $4^{\prime}-$ phosphopantothenic acld obtained was further purified. A portion of the lithlum salt ( $80 \mathrm{mg}$ ) was dissolved tn water $(12 \mathrm{ml})$ and applied to a column of DEAE-cellulose (chloride form, $2 x$ $30 \mathrm{~cm}$ ). Elution was carried out by a $1100 \mathrm{ml}$ linear salt gradient (0-0.05 M LICl in $0.003 \mathrm{M} \mathrm{HC1)}$, and the triltthium salt was obtained (yield, $48 \mathrm{mg}$; Anal. Calcd. for $\mathrm{C}_{9} \mathrm{H}_{15} \mathrm{O}_{8} \mathrm{NPLI}_{3} \cdot 4 \mathrm{H}_{2} \mathrm{O}: \mathrm{C}, 27.78$;
E, 5.96;N,3.60\%. Phosphorus : pantothenic acid, $1: 1$. Found: C, 27.49; H,6.00; N,3.627. Phosphorus : pantothenic ac1d, $1: 1.04)$.

ii) 4'-Phosphopantetheine. a) The reaction mixture $(20 \mathrm{ml})$ contalning 150 umoles of $4^{\prime}$-phosphopantothenlc acld (Itthium salt prepared by the above method), 300 pmoles of cysteine, 300 umoles of CTP, 200 moles of $\mathrm{MgSO}_{4}, 3$ moles of potassium phosphate buffer, $\mathrm{pH} 6.5,40 \mathrm{mg}$ of sodium laurylsulfate, and washed cells of Brevibacterium ammoniagenes ( $1.2 \mathrm{~g})$ was Incubated for 5 hr at $37^{\circ} \mathrm{C}$. Then, the mixture was worked up as described above. The resultant supernatant was diluted to $100 \mathrm{ml}$ with water and applied to a column of Dowex $1 \times 2$ (chloride form, $2 \times 20 \mathrm{~cm}$ ), and the column was washed with water $(400$ mi). Elution with $0.005 \mathrm{M} \mathrm{HCl}$ removed CMP. $4^{\prime}$-Phosphopantethelne was eluted together with CDP with $0.01 \mathrm{M}$ LICI in $0.01 \mathrm{M} \mathrm{HCl}$. Approprlate fractions were combined, adjusted to $\mathrm{pH} 5$, and evaporated to dryness. The residue was dissolved in a small volume of methanol and insoluble materials were filtered out. The clear solution was treated wth Amberlite IR-120 ( $\mathrm{H}^{+}$form) and the acldic eluate was neutralized with $\mathrm{Ca}(\mathrm{OH})_{2}$. This was applied to a column of DEAE-cellulose (chloride form, $2 x$ $30 \mathrm{~cm})$. Elution was carried out by a $1100 \mathrm{ml}$ linear salt gradient (0-0.03 M $\mathrm{CaCl}_{2}$ in $\left.0.003 \mathrm{M} \mathrm{HCl}\right)$. For both inltial and gradient elutions, the eluting solution contained $0.1 \%$ 2-mercaptoethanol. 4'-Phosphopantetheine was well separated from the remaining CDP. APProprlate fractions were comblned, neutralized wth $\mathrm{Ca}(\mathrm{OH})_{2}$, concentrated to a small volume, clarifted, and then evaporated to dryness. The residue was dissolved in a small volume of ethanol. Addition of 15 volumes of ether gave the calcium salt of $4^{\prime}$-phosphopantethe1ne. The salt was collected, washed, and then dried (yleld, $41 \mathrm{mg}$ ). The product was homogeneous with respect to phosphorus and sulfhydryl on paper chromatogram. Its $R f$ value was the same as that of the product of CoA digestion with venom phosphodtesterase. Treat- 
ment wth $\mathrm{H}_{2} \mathrm{O}_{2}$ gave the disulfide, which showed an $R f$ value identical to that of an authentic 4'-phosphopantethelne (disulfide form). Hydrolysis of the loolated sample with alkaline phosphatare gave a sulfhydryl compound ( $R f \quad 0.84$ In a solvent system of $n$-butanol-acetic acid-water $(5: 2: 3$, by vol.)) and 1norgan1c phosphate. Treatment of the d1geation product with $\mathrm{H}_{2} \mathrm{O}_{2}$ gave a disulflde which was 1dentical with an authentic pantethine ( $R f$ 0.81 in a solvent system of $n$-butanol-acetic acid-water $(5: 2: 3$, by vol.)). The isolate was partially active in enhancing the growth of Lactobacillus bulgaricus B1 without phoephatase digestion, and released the theoretical amount of pantetheine after phosphatase digeation. The NMR spectrum is shown in Fig. 3. The resemblance of the splitting pattern to that of 4"-phosphopantothenlc acld suggests that phosphorus attaches to the $4^{\prime}$-hydroxyl group 1 in the pantothenoyl molety. Anal. Calcd. for $\mathrm{C}_{11} \mathrm{H}_{21} \mathrm{O}_{7} \mathrm{~N}_{2} \mathrm{SP}-$ $\mathrm{Ca} \cdot 3 \mathrm{H}_{2} \mathrm{O}: \mathrm{C}, 29.33 ; \mathrm{H}, 6.04 ; \mathrm{N}, 6.22 \%$.

Phosphorus : pantothenic acid : sulfhydryl, $1: 1: 1$. Found: C, 28.94; H, 5.99; N,6.22\%. Phosphorus : pantotientc acid : sulfhydryl, $1: 0.98: 0.92$.

b) Brevibacterium anmoniagenes was cultivated in the same medium as described above. (In this case, AMP was omitted.). After 3 days of cultivation, $0.2 \mathrm{~g}$ of calcium pantothenate, $0.2 \mathrm{~g}$ of cystelne, $0.15 \mathrm{~g}$ of CMP, $0.15 \mathrm{~g}$ of IMP, and $0.1 \mathrm{~g}$ of cetylpyridinium chloride were added to the culture $(100 \mathrm{ml})$. Then the culture was continued for a further 2 days. The cultured broth (100 m1) was worked up as described above. The supernatant was applied to a colum of charcoal $(4 \times 8 \mathrm{~cm})$, and the adsorbed substances were eluted with $40 z$ acetone contalning 0.0287 ammonla. The acldic eluate was concentrated to $50 \mathrm{ml}$. Twenty $\mathrm{ml}$ of 2-mercaptoethanol were added to the concentrate, which was then left at $10^{\circ} \mathrm{C}$ overn 1 ght. The mixture was adfusted to $\mathrm{pH} 7.5$ with $\mathrm{Ca}(\mathrm{OH})_{2}$, diluted to $200 \mathrm{ml}$, and applled to a colum of DRAE-cellulose (chloride form, $2.5 \times 30 \mathrm{~cm}$ ). Elution was carried out by a $5000 \mathrm{ml}$ 11near salt gradient

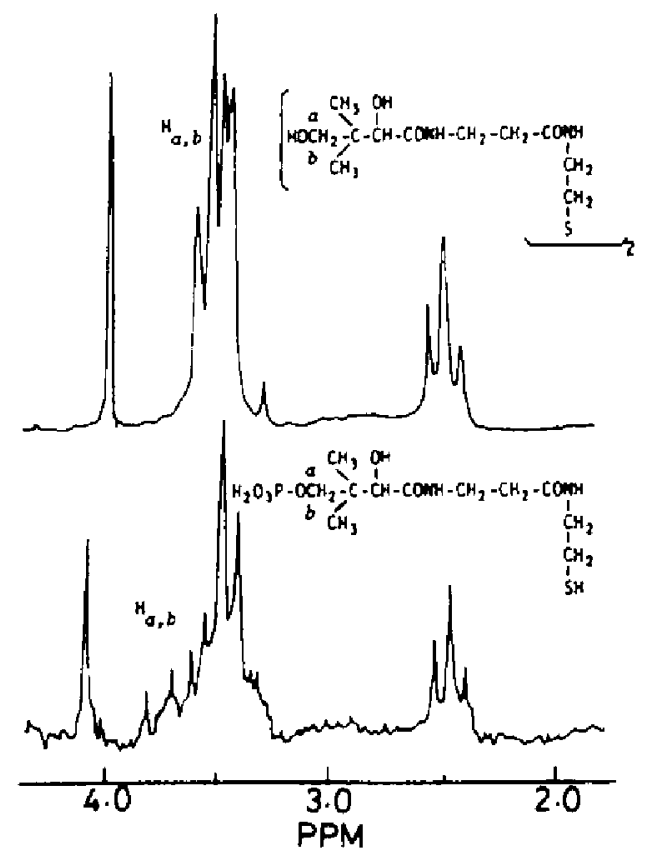

FIG. 3. Comparat 1ve NMR Spectra of 4'-Phosphopantetheine and Pantethine.

NMR spectra were measured on a hitach Perk1n-Elmer R-22 spectrometer at $90 \mathrm{MHz}$ in $\mathrm{D}_{2} \mathrm{O}$ wth DSS as the internal standard. Top, pantethine; bottom, 4'-phosphopantethe1ne.

(0-0.03 $\mathrm{M} \mathrm{CaCl}_{2}$ in $0.003 \mathrm{M} \mathrm{HCl}$ contalnIng $0.1 \%$ 2-mercaptoethanol). Appropr1ate fractions were combined, and worked up as described above to give the calcium salt of $4^{\prime}$-phosphopantethelne (yleld, $135 \mathrm{mg}$; purity, based on pantothenic acid content, 74-80z). This was further purified by a DEAE-cellulose column (chloride form, $2 \times 35 \mathrm{~cm}$ ) chromatography using a $2000 \mathrm{ml}$ linear salt gradient $\left(0-0.03 \mathrm{M} \mathrm{CaCl}_{2}\right.$ in $0.003 \mathrm{M} \mathrm{HCl}$ contatning 0.17 2-mercaptoethano1). Then flnally 4'-phosphopantethelne was obtalned as the calctum salt (yield, 83 m8; Anal. Calcd. for $\mathrm{C}_{11} \mathrm{H}_{21} \mathrm{O}_{7} \mathrm{~N}_{2} \mathrm{SPCa} \cdot 3 \mathrm{H}_{2} \mathrm{O}$ : C, 29.33; B, 6.04; N,6.22\%. Phosphorus: pantothenlc acld : oulfhydryl, $1: 1: 1$. Found: $C, 29.57$; B,5.89; N,6.427. Phosphorus : pantothenic acid : sulfhydryl, $1: 1.05: 0.98$ ).

The mechanism of the accumulation of the Intermediates of COA blosynthesis will be discussed in following sections. 
Section VII.

Microbial Formations of the Intermediates of Coenzyme A Biosynthesis and their Control by Nucleotides i)

Mcroblal formation of $4^{\prime}$-phosphopantothenic acid, 4'-phosphopentetheine, and $3^{\prime}$-dephospho-CoA were described in connection with a higher accumulation of CoA.

Afr drled cells of Brevibacterium ammoniagenes IFO 12071 phosphorylated pantothentc acid in the presence of ATP. ATP could be subst1tuted for, partly, by ITP, GTP, ADP, UTP, and CTP. 4'-phosphopantethelne was converted to CoA only when incubated with ATP. All the other nucleotides tested appeared to lack the abllity to couple with 4'-phosphopantetheine. 4'-Phosphopantetheine, but not CoA, was accimulated selectively from pantothenlc acid, cysteine, and a nucleotide triphosphate other than ATP. It was also accumlated when pantethine was incubated with ITP, GTP, or UTP. In a oimilar fashion, $4^{\prime}$-phosphopantothenic acid and $4^{\prime}$-phosphopantetheine were able to be accumulated in the culture broth of Brevibacterium ammoniagenes.

3'-Dephospho-CoA was synthesized by treating the reaction $\mathrm{mix}-$ ture which had accumulated CoA with $3^{\prime}$-rucleotldase of Bacillus subtilis IFO 3032.

Nucleotide speciffcity of $4^{\prime}$-phosphopantothenoylcysteine synthetase, and that of $3^{\prime}$-dephospho-CoA kinase were investigated using drted cells of Brevibacterium ammoniagenes.

\section{INTRODUCTION}

In the preceding sections, microbial formations of intermediates of CoA synthesis from pantothentc actd with higher ylelds were described. They were 1solated and 1dentified as 4'-phosphopantothenic acid and $4^{\prime}$-phosphopantetheine.

This section describes some factors affecting the selective formation of the intermedlates of CoA blosynthesis and their control by nucleotides in connection with a higher formation of CoA.

\section{MATERIALS AND METHODS}

Chemicals. 4'-Phosphopantothenic acid, 4'-phosphopantetheine, 3'-dephospho-CoA, and COA were synthesized microbiologically as described in the previous sections. ATP, ADP, GTP, GDP, CTP, and UTP were gifts of Kyowa Hakko Kogyo Co., Ltd., Tokyo. DEAE-cellulose (0.9 meq/g) was provided by Green Cross Corporation, Osaka. CDP was purchased from
Selkagaku Kogyo Co., Ltd., Tokyo. Pantethine and Intestinal alkaline phosphatase (Type I and Type IV) from calf mucosa were obtained from Sigma Chemlcal Co., St. Louls. Acetylphosphate was prepared by the method of Avison (42). All other reagents were commercial products of an analytical grade of purity.

Microorganism and cultivation. Brevibacterium ammoniagenes IFO 12071 was used. The media for the bacterium and cultivation techniques have been described prevtously (see Section I and IV).

Preparation of dried cells. Atr dried cells of the bacterium were prepared according to the method described previously (see Section I).

Assay of pantothenates. Pantothenic actd was measured microbiologically with Saccharomyces carlsbergensis ATCC 9080 (46). 4'-Phoephopantothenic acid was 
measured by following the disappearance of pantothenic acid in the reaction $m i x-$ ture or culture broth. This was checked by measuring the recovery of pantothenic acid after digestion with alkaline phosphatase. CoA was measured by the phosphotransacetylase method of Stadtman et al. (43) using the enzyme of Escherlchia coli Crookes ARU 0001 as deacribed in Section I. Total pantothenate was measured by the method of Novel11 (47). The amount of the intermediates of CoA blosynthesis ( $4^{\prime}$-phosphopantothenoylcysteine, 4'-phosphopantetheine, and $3^{\prime}$-dephospho-CoA) or $4^{\prime}-$ phosphopantethelne was calculated by subtracting pantothenic actd, 4'-phosphopantothenic acid, and CoA from the total pantothenate. In some cases, 4'phosphopantetheine was also measured as pantetheine with Lactobacillus bulgaricus BI (94) after digesting the sample with alkaline phosphatase.

Paper chromatography. Ascending paper chromatography was performed on Toyo Rosh1 No.53 filter paper using solvent $I, n$-butanol-acettc acid-water ( $5: 2: 3$, by vol.); solvent II, $n$-propanol-28\% ammonfum hydroxide-water (6:3:1, by vol.); and solvent III, 1sobutyrlc acid-0.5 $\mathrm{N}$ ammonium hydroxide-0.1 M EDTA $(100: 60: 1.6$, by vol.). Nucleotides were located with a UV-lamp. Phosphorus-containing compounds were located with Hanes and Isherwood spray (50) followed by ultraviolet irradiation; sulfhydryl and disulfide compounds were detected with Toennies and Kolb spray (51).

Preparation of 3'-nucleotidase. A crude $3^{\prime}$-nucleotidase of Bacillus subtilis IFO 3032 was prepared according to the method of Igarashl and Kakinuma (95).

Other methods. Adenine content was determined by ultraviolet absorption in $0.1 \mathrm{M} \mathrm{HCl}$ using $E_{260}=15,000$ as a standard value. Phosphorus was measured by the method of Allen (87) and sulfhydryl by the method of Ellman (49).

\section{RESULTS}

\section{Phosphorylation of pantothenic acid}

When cysteine was omitted from the complete reaction mixture, almost all the pantothenic acid initially present was consumed without the formation of CoA. It was completely recovered by treatment with alkaline phosphatase. Thls phosphorylaion of pantothenlc acid was dependent on ATP. ATP could be substltuted for, partly, by ITP, GTP, UTP, ADP, and CTP (Table I). Simflar results were also obtalned when each nucleoside monophosphate as indicated

TABLE I. NUCLEOTIDE REQUIRPMEAT FOR THE PHOSPHORYLATION OF PANTOTRENIC ACID

(A) Two umoles of godium pantothenate (PaA) and 10 umoles of nucleotide as indicated were Incubated at $37^{\circ} \mathrm{C}$ for $6 \mathrm{kr}$ with 10 fmoles of $\mathrm{MgSO}_{4}, 150$ umoles of potassium phosphate buffer, $\mathrm{pH}$ 6.5, 1 trg of godium laurylsulfate, and $100 \mathrm{mg}$ of dried cells of Brevibacterium ammoniagenes in a total volume of $1 \mathrm{ml}$.

(B) Brevibacterium ammoniagenes was cultivated in the medium as described previously (see Section IV.) except that AMP was omitted. PaA (calcium salt), nucleotide as indicated, and cetylpyridinium chloride were added to the 3 day cultures at the concentration of $2 \mathrm{mg} / \mathrm{ml}, 2 \mathrm{mg} / \mathrm{ml}$, and $1 \mathrm{mg} / \mathrm{ml}$, respectively, and the cultivation was continued for a further 2 days.

After bolling the reaction mixture for 5 min or the cultured broth for $3 \mathrm{~min}$, cells were removed by centrifugation. The supernatant was employed in the determination of PaA.

\begin{tabular}{|c|c|c|c|}
\hline \multicolumn{2}{|c|}{ (A) } & \multicolumn{2}{|c|}{ (B) } \\
\hline $\begin{array}{c}\text { Nucleotide } \\
\text { added }\end{array}$ & $\begin{array}{c}\text { PaA } \\
\text { consumed } \\
(\mu \mathrm{moles} / \mathrm{ml})\end{array}$ & $\begin{array}{l}\text { Nucleotide } \\
\text { added }\end{array}$ & $\begin{array}{c}\mathrm{PaA} \\
\text { consumed } \\
(\mathrm{mg} / \mathrm{ml})\end{array}$ \\
\hline ATP & 2.0 & AMP & 2.0 \\
\hline ITP & 1.9 & IMP & 1.0 \\
\hline GTP & 1.8 & GMP & 2.0 \\
\hline urP & 1.2 & UMP & 1.5 \\
\hline CTP & 0.4 & CMP & 0.7 \\
\hline ADP & 1.8 & None & 0.5 \\
\hline None & 0.0 & & \\
\hline
\end{tabular}

in Table $I$ and pantothenic acid were added to the culture of Brevibacterium ammoniagenes. The 1solation and 1dentification of 4 "-phosphopantothenic acld have been described in Section VI. 
Synthesis of 4'-phopshopantetheine

Coupling of 4'-phosphopantothenic acid with cysteine. As can be seen in Table II, 4'-phosphopantothenlc acid was most rapidly coupled with cysteine when CTP was added to the reaction mixture. CTP could be substituted for, partly, by CDP, ATP, and ADP, but GTP, UTP, and ITP were Ineffective under the conditions tested. The reaction with CTP, CDP, or ADP gave $4^{\prime}$-phosphopantetheine, while CoA was the main product in the reaction mixture with ATP. Isolation and Identification of $4^{\prime}$-phosphopantetheine have been described in Section VI.

TABLE II, RUCLEOTIDE REQUIREMENT POR THE COUPLING OF \&'-PHOSPHOPANTOTHENIC ACID WTTH CYSTEINE

The reaction minture contained, in $1 \mathrm{ml}$, 5 rooles of $4^{\prime}$-phosphopantothenic actd (P-PaA), 10 proles of cystelne, 15 umoles of nucleotide as Indicated, 10 moles of $\mathrm{MgSO}_{4}, 150$ umoles of potasaium phosphate buffer, $\mathrm{pH} 6.5,1 \mathrm{mg}$ of oodiun laurylsulfate, and $60 \mathrm{mg}$ of drled cells of Brevibacterium ammoniagenes. The react 100 was carried out for $3 \mathrm{hr}$ at $37^{\circ} \mathrm{C}$, and terminated by immersing the tube in botlIng vater for $5 \mathrm{~min}$. After adding $3 \mathrm{ml}$ of vater, cells were removed by centrifugation. The supernatant was employed in the determination of the products.

\begin{tabular}{|c|c|c|}
\hline $\begin{array}{l}\text { Nucleot Ide } \\
\text { added }\end{array}$ & $\begin{array}{c}\text { P-PaA coupled } \\
(\mu \mathrm{moles} / \mathrm{ml})\end{array}$ & $\begin{array}{l}\text { CoA formed } \\
\text { (umoles/ml) }\end{array}$ \\
\hline CTP & 3.4 & 0.05 \\
\hline $\mathrm{CDP}$ & 3.2 & 0.03 \\
\hline ATP & 3.1 & 2.80 \\
\hline ADP & 2.1 & 0.65 \\
\hline GTP & 0.1 & 0.15 \\
\hline ITP & 0.0 & 0.05 \\
\hline OTP & 0.3 & 0.05 \\
\hline None & 0.0 & 0.02 \\
\hline
\end{tabular}

Coupling of $4^{\prime}$-phosphopantetheine with ATP. $4^{\prime}$-Phosphopantetheine was converted to CoA only when incubated wth ATP. All other nucleotides triphosphates seemed to lack the ability to couple with this substrate (Table III).

Synthesis of 4'-phosphopantetheine from pantothenic acid and cystelne. Broad opecificity for nucleotide in the
TABLE III. COUPLING OF $4^{\circ}$-PHOSPYOPAKTETREIKE WITH NUCLEOTIDE

The reaction mixture contained, in $0.5 \mathrm{ml}$, 1 umole of $4^{\prime}$-phosphopantetheine (P-PaSH), 5 moles of nucleotide as indicated, 5 moles of cystelne, 5 woles of $\mathrm{MgSO}_{4}, 75$ umoles of potasstum phosphate buffer, pH 6.5, $0.5 \mathrm{ng}$ of oodium laurylgulfate, and $50 \mathrm{mg}$ of dried cells of Brevibacterium amoniagenes. The resction was carried out for $2 \mathrm{hr}$ at $37^{\circ} \mathrm{C}$, and terminated by fmmersing the tube in bolling vater for $5 \mathrm{~min}$. After adding $1.5 \mathrm{ml}$ of water, cella vere removed by centrifugation. The supernatant was employed in the determination of the producta.

\begin{tabular}{ccc}
\hline $\begin{array}{c}\text { Hucleotide } \\
\text { added }\end{array}$ & $\begin{array}{c}\text { P-PaSh consumed } \\
(\mu \operatorname{moles} / \mathrm{ml})\end{array}$ & $\begin{array}{c}\text { CoA formed } \\
(\mu \mathrm{moles} / \mathrm{ml})\end{array}$ \\
\hline ATP & 2.0 & 2.03 \\
GTP & 0.5 & 0.16 \\
ITP & 0.4 & 0.15 \\
UTP & 0.2 & 0.05 \\
CTP & 0.0 & 0.03 \\
None & 0.0 & 0.04 \\
\hline
\end{tabular}

a) P-PaSB vas meagured as pantetheine by Lactobaclllus bulgarlcus Bl (94) after digesting the mixture with alkaline phosphatase (Type IV).

phosphorylation of pantothenic acid and its restriction in the coupling of $4^{\prime}-$ phosphopantethelne with ATP strongly suggest the possibility of synthesizing $4^{\prime}$-phosphopantetheine, but not CoA, from pantothentc actd and cysteine, if ATP is absent in the reaction mixture. As shown in Table IV, pantothenic acid and cysteine, when incubated with CTP and GTP, ITP, or UTP, gave $4^{\prime}$-phosphopantethelne selectively, while the reaction with ATP gave a high accumulation of CoA.

Isolation of $4^{\prime}$-phosphopantethelne from the reaction mixture with CTP and ITP was carried out. The reaction mixture $(40 \mathrm{ml})$ contalning $300 \mu \mathrm{moles}$ of

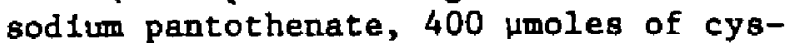
telne, 600 umoles of ITP, 400 umoles of CTP, 400 umoles of $\mathrm{MgSO}_{4}, 6$ moles of potassium phosphate buffer, pH $6.5,40$ mg of sodium laurylsulfate, and $4 \mathrm{~g}$ of dried cells of Brevibacterium anmoniagenes was incubated for $8 \mathrm{hr}$ at $37^{\circ} \mathrm{C}$. Then, the mixture was immersed for 5 min in botling water and the cells were removed by centrifugation. The super- 
TABLE IV. HUCLBOTIDE RRQUIREMENT POR THE SYMTHES IS OF $4^{\prime}-$ PHOSPHOPANT ETHEI HE PROH PANTOTEENIC ACID AND CYSTEINE

Two rmoles of sodium pantuthenate ( $\mathrm{FaA}, 4$ umoles of cysteine, 10 umoles of $\mathrm{MgSO}_{4}, 150$ proles of potassium phoophate buffer, pH 6.5 , $1 \mathrm{mg}$ of sodfur laurylsulfate, and $100 \mathrm{mg}$ of dried cells of Brevibacterium ammiagenes were Incubated for $6 \mathrm{hr}$ at $37^{\circ} \mathrm{C}$ with nucleotide a indicated in a total volume of $1 \mathrm{ml}$. The reaction was terminated by lmmersing the tube in bolling water for 5 min. After adding 3 al of vater, cella vere removed by centrifugation. The aupernatant was employed in the determination of the products.

\begin{tabular}{lccc}
\hline $\begin{array}{l}\text { Nucleotfde } \\
\text { added }\end{array}$ & \multicolumn{3}{c}{ Compound found (umoles/ml) } \\
\cline { 2 - 4 } & PaA + P-PaAb) & P PaSt C) & CoA \\
\hline CTP & 1.40 & 0.61 & 0.01 \\
CTP + ATP & 0.09 & 0.61 & 1.30 \\
CTP + GTP & 0.38 & 1.66 & 0.30 \\
CTP + ITP & 0.38 & 1.66 & 0.19 \\
CTP + UTP & 0.86 & 1.14 & 0.08
\end{tabular}

a) The amounts of nucleotides added were: CTP, 8 uroles; others, 10 umoles.

b) P-PaA: 4'-phosphopantothenic acid.

c) $4^{\text {'}}$-Phosphopantetheine (P-PaSH) vas measured as pantetheine by Lactobacillus bulgaricus B1 (94) after digeating the mixture with alkaline phosphatase (Type I). The phosphatase used contains phosphodiesterase activity, thus it is able to hydrolyze COA to yield pantetheine. The values presented are calculated by subtracting the amount of Cos produced from that detected as pancetheine. Therfore, the values are given as a sum of P-PaSH and 3'-dephospho-CoA.

netant was applied to a column of char$\cos 1(1.6 \times 7 \mathrm{~cm})$, and the adsorbed substances were eluted with $40 \%$ acetone conta1ning 0.0287 anmonia. The acidic eluate was concentrated to about $20 \mathrm{ml}$. 2-Mercaptoethanol $(10 \mathrm{ml})$ was added to the concentrate, which was then left at $10^{\circ} \mathrm{C}$ overnight. The mixture was adjusted to $\mathrm{pH} 7.5$ with $\mathrm{Ca}(\mathrm{OH})_{2}$, diluted to $100 \mathrm{ml}$, and applied to a column of DEAEcellulose (chloride form, $1.8 \times 25 \mathrm{~cm}$ ). Elution was carried out by a $3000 \mathrm{ml}$ Ilnear salt gradient $\left(0-0.03 \mathrm{M} \mathrm{CaCl}_{2}\right.$ in 0.003 M HCl contalning $0.1 \%$ 2-mercaptoethano1). $4^{\prime}$-Phosphopantetheine was eluted, followed by IMP. Approprlate fractions were combined, and worked up as described previously (see Section VI) to give a white powder (yleld, $45 \mathrm{mg}$; ratlo of phosphorus : pantethelne : aulf- hydryl, $1: 0.92: 0.85$ (required, $1: 1: 1$ ); Rf in solvent $I, 0.66$ and in solvent II, 0.30 ).

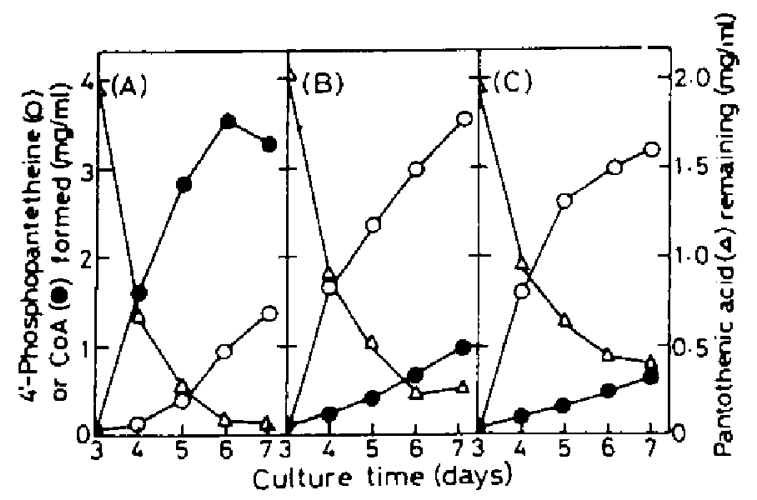

FIG. 1. Selective Accumulation of $4^{1}$-Phosphopantetheine in the Culture Broth.

Brevibacterium ammoniagenes was cultivated in the medium as described in section IV except that AMP was omitted. To the 3 day culture, calcium pantothenate ( $2 \mathrm{mg} / \mathrm{ml}$ ), cysteine (2 $\mathrm{mg} / \mathrm{ml})$, nucleotides (1.5 $\mathrm{mg} / \mathrm{ml} \mathrm{each})$ as $1 \mathrm{n}-$ dicated, and cetylpyridinium chloride ( $1 \mathrm{mg} / \mathrm{ml}$ ) were added, and the cultivation was continued. One $\mathrm{ml}$ of the broth was pipetted from the shaking flask at $24 \mathrm{hr}$ intervals, botled for 3 min, and contrifuged. The supernatant was employed in the determination of the products. The nucleotides added were CMP and AkP (A), CMP and GMP (B), or CMP and UMP (C). The amount of $4^{\prime}$-phosphopantethe1ne was calculated by subtracting the amounts of CoA, 4'-phosphopantothenic acid, and pantothenic acid from the total pantothenace. Therefore, the values are given as a sum of $4^{\prime}$-phosphopantetheine, 4 "-phosphopantothenoylcystelne, and 3 "-dephospho-CoA.

This selective synthesis of $4^{\prime}$-phosphopantetheine was also observed when pantothenic acld, cysteine, CMP, and GMP or UMP were added to the cultures of Brevibacterium ammoniagenes (FIg. 1). Isolation and characterization of the product from the culture broth was described in Section VI.

Another attempt to synthesize $4^{\prime}$ phosphopantethelne without the formation of CoA was tried. Incubation of pantethine with GTP, ITP, or UTP also gave 4'-phosphopantetheine, but not CoA. Isolation of the product from the reaction mixture with ITP was carried out according to a similar procedure as described above, and the product was identifled as 4 '-phosphopantetheine. 
Synthesis of 3'-dephospho-COA from pantothenic acid, cysteine, and ATP

Kak1numa and Igarash1 (96) reported that the $3^{\prime}$-nucleotidase of Bacillus subtilis IFO 3032 attacks the $3^{\prime}$-pos1tion in the CoA molecule, and Kurooka et a 1. (54) applied this enzyme to prepare $3^{\prime}$-dephospho-CoA from commercial CoA. In order to accumulate $3^{\prime}$-dephospho-CoA, the reaction mixture with accumulated $C O A$ was treated with the $3^{\prime}-$ nucleotldare of Bacillus subtilis IFO 3032. The reaction mixture (40 ml) containing 300 umoles of sodium pantothenate, 400 umoles of cysteine, 600 umoles of ATP, 400 umoles of $\mathrm{MgSO}_{4}, 6$ moles of Tris-HCl buffer, $\mathrm{pH} 7.2,40 \mathrm{mg}$ of sodfum laurylsulfate, and $4 \mathrm{~g}$ of dried cells of Brevibacterium ammoniagenes was incubated for $8 \mathrm{hr}$ at $37^{\circ} \mathrm{C}$. Then the mixture was diluted to $80 \mathrm{ml}$, Immersed for $5 \mathrm{~min}$ in boiling water, and the cells were removed by centrifugation. The supernatant (70 ml) containing 45 mg of CoA was combined with a solution of crude $3^{\prime}$-nucleotidase $(30 \mathrm{ml})$, then the mixture was incubated at $37^{\circ} \mathrm{C}$. The CoA inltially present in the reaction mixture was inactivated gradually. After $6 \mathrm{hr}$ incubation, the mixture was bolled for $5 \mathrm{~min}$, centrifuged, and applied to a colum of charcoal ( $1.6 \times 7$ cm), Elution, concentration, and treatment with 2-mercaptoethanol were carried out as described above. The resultant solution was adjusted to $\mathrm{pH} 7.5$ with L1OH, diluted to $100 \mathrm{ml}$, and applied to a column of DEAE-cellulose (chlortde form, $1.8 \times 25 \mathrm{~cm}$ ). Elution was carried out by a $4000 \mathrm{ml}$ linear salt gradient (0-0.07 $\mathrm{M} \mathrm{L1Cl}$ in $0.003 \mathrm{M} \mathrm{HCl}$ containing $0.1 \%$ 2-mercaptoethanol). Appropriate fractions contalning $3^{\dagger}$-dephospho$\operatorname{CoA}$ were combined, and worked up as described previously (see Section V), to give the lithium salt (yleld, $33 \mathrm{mg}$; ratio of adenosine : phosphorus : sulfhydry1, 1:1.88:0.85, (required, 1:2:1); Rf in solvent III, 0.67$)$. Elution proflles from small scale experfments before and after treatment with the $3^{\prime}-$ nucleotidase are shown in Fig. 2 .

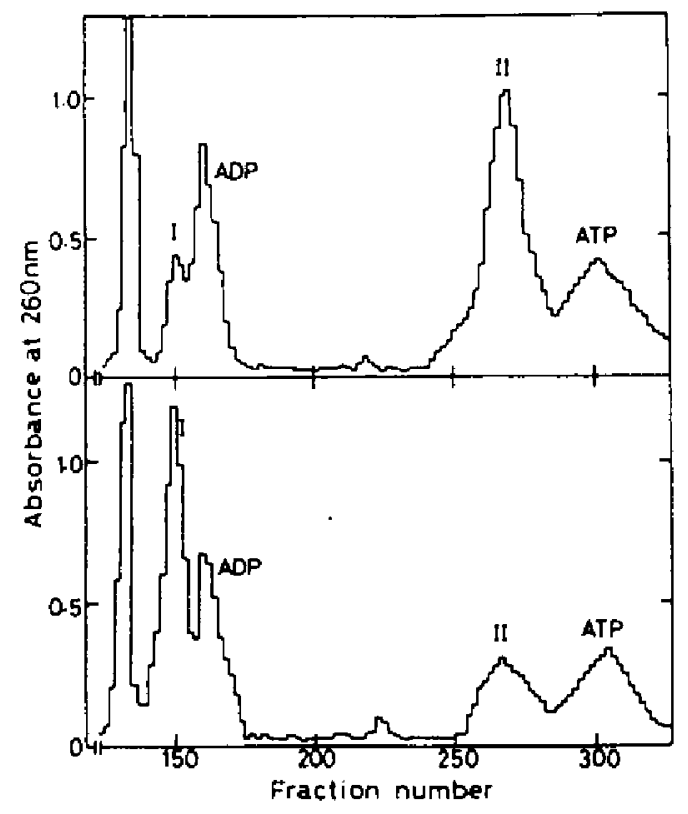

FIG. 2. Conversion of Formed CoA to $3^{\prime}-\mathrm{De}-$ phospho-CoA by $3^{\prime}$-Nucleotidase of Bacillus subtilis IFO 3032 .

The reaction mixture containing, in $6 \mathrm{ml}$, 45 umoles of sodium pantothenace, 60 umoles of cysteine, 90 umoles of ATP, 60 umoles of $\mathrm{MgSO}_{4}, 900$ umoles of Tris-HCl buffer, pH 7.2, $6 \mathrm{mg}$ of sodium laurylsulfate, and $600 \mathrm{mg}$ of dried cells of Brevibacterium ammoniagenes was incubated for $1.0 \mathrm{hr}$ at $37^{\circ} \mathrm{C}$. The reactIon was terminated by tmmersing the tube in bolling water for $5 \mathrm{~min}$, and cells were removed by centrifugation. Two ml of the supernatant were combined with $2 \mathrm{ml}$ of crude $3^{\prime \prime}$-nucleotidase. The mixture was incubated for $4 \mathrm{hr}$ at $37^{\circ} \mathrm{C}$, bolled for $5 \mathrm{~min}$, centrifuged, treated wth 2 ml of 2-mercaptoethanol for $6 \mathrm{hr}$ at $10^{\circ} \mathrm{C}$, diluted to $80 \mathrm{mi}$ with water, and applied to a colunm of DEAE-cellulose (chloride form, $1.6 \times 60 \mathrm{~cm}$ ). Another $2 \mathrm{ml}$ of the supernatant, not treated wth 3'-nucleotidase, was treated with $2 \mathrm{ml}$ of 2mercaptoethanol for $6 \mathrm{hr}$ at $10^{\circ} \mathrm{C}$, diluted to $80 \mathrm{ml}$, and applied to a simflar colum of DEAE-cellulobe. Elution was carried out by a $1100 \mathrm{ml}$ linear salt gradient $(0-0.1 \mathrm{M} \mathrm{LICl}$ in $0.003 \mathrm{H} \mathrm{HCl}$ containing 0.17 2-mercaptoethanol). Fractions of $3.5 \mathrm{ml}$ each vere collected.

Top, before treatment wth $3^{\prime}$-nucleotidase; bottow, after treatment ith $3^{\prime}$-nucleotidase. Peak I, 3'-dephospho-CoA; Peak II, CoA.

\section{Formation of COA from 3'-dephospho-COA} with various nucleotides

$3^{\prime}$-Dephospho-CoA was converted to CoA in the presence of ATP. When ATP was replaced with ADP, GTP, UTP, or CTP, 
TABLE V. PORMATION OF COA FROM 3'-DEPHOSPHO-COA WTTH VARIOUS NUCLEOTIDES

The reaction mixture contained, in $0.5 \mathrm{ml}$, 1 unole of $3^{\prime}$-dephospho-CoA, 5 umoles of aucleotide as Indicated, 5 pmoles of $\mathrm{MgSO}_{4}$, 75 ymoles of potasaim phoephate buffer, $\mathrm{pH}$ $6.5,0.5 \mathrm{mg}$ of sodium lauryloulfate, and 50 ang of Brevibacterium ammoniagenes. The reaction was carrledout for 2 hr at $37^{\circ} \mathrm{C}$, and terminated by lnersing the tube in bolling water for 5 win. After adding $1.5 \mathrm{ml}$ of water, cells were removed by centrifugation. The oupernatant uas employed in the determination of the product.

\begin{tabular}{cc}
\hline $\begin{array}{c}\text { Hucleotide } \\
\text { added }\end{array}$ & $\begin{array}{c}\text { CoA formed } \\
\text { (Hmoles/ml) }\end{array}$ \\
\hline ATP & 2.13 \\
ADP & 1.34 \\
GIP & 1.24 \\
ITP & 1.37 \\
UIP & 0.45 \\
CIP & 0.50 \\
None & 0.07 \\
\hline
\end{tabular}

accumulation of CoA was also observed. The results are given in Table $V$.

\section{DISCUSSION}

A further step in the successful process for the production of CoA has now been given: A large amount of $4^{\prime}$ phosphopantetheine was selectively accumulated without the formation of $\mathrm{COA}$ by replacing ATP with other nucleotides. It was also produced in a higher yleld when Brevibacterium ammoniagenes was cultivated with pantothenic acid, cystelne, CMP, and UMP (or GMP). 3'-Dephospho-CoA was obtained by converting the CoA formed by treating it with $3^{\prime}-$ nucleotldase of Bacillus subtilis IFO 3032. The present process described here might be sultable not only for a blochemical laboratory method but also for further large scale production, because the process is simple and rapid, and requires no apectal equipment.

As w111 be described in the next section, an interesting property of the purifled pantothenate kinase of Brevibacterium ammoniagenes is its partial lack of speciflcity with regard to the nucleotide. In the present work, experimenta with dried cells and growing cells also showed this broad spectficity for the nucleotide. Further, CTP and ADP, which are 1nactive nucleotides with the purified pantothenate k1nase (see the next section), showed activity wth drled cells or growing cells. On the contrary, only ATP could couple with $4^{\prime}$-phosphopantethelne and yleld CoA. Al1 other nucleotides tested appeared to lack the ablifty to couple with 4'phosphopantetheine. The direct and exclusive accumulation of $4^{\prime}$-phosphopantetheine from pantothenic acld and cysteine by the bacterium may be attributed to the broad specificity for nucleotide in the phosphorylation of pantothenic acid and its restriction in the coupling of $4^{\prime}$-phosphopantetheine with ATP. Another route for the accumulation of 4 "-phosphopantethelne, which was shown by Incubating pantethine with all the nucleotides tested except ATP, may also be attributed to the facts as described above.

Now, Including CoA 1tself, all the intermediates of CoA biosynthesis from pantothenlc acid, though 4'-phosphopantothenoylcysteine is an exseption, have been able to be synthesized conveniently by this microbial process. 


\author{
Section VIII. \\ Purification and Properties of Pantothenate Kinase \\ from Brevibacterium ammoniagenes IFO $12071^{\text {D) }}$
}

\begin{abstract}
Pantothenate kinase (ATP : pantothenate 4'-phosphotransferase, E. C. 2.7.1.33) was purifled about 200-fold from the cell extract of Brevibacterium anmoniagenes IFO 12071 by amonium sulfate fractlonat1on, DEAE-cellulose chromatography, and Sephadex G-150 gel filtration. The purtfied enzyme gave a single band on polyacrylamide gel electrophoresis. The molecular velght was calculated approximately 45,000. The enzyme catalyzed the formation of $4^{\prime}$-phosphopantothenle acld and ADP from pantothenlc acid and ATP in the presence of $\mathrm{Kg}^{2+}$, ATP could be subatituted for, partly, by ITP, GTP, and UTP. The enzyme phosphorylated not only pantothenic acld, but also pantothenoylcystelne, pantethelne, and pantotheayl alcohol. Apparenc xulues were $6.7 \times 10^{-5} \mathrm{M}$ for pantothenlc acld, $3.5 \times 10^{-5} \mathrm{H}$ for ATP, and $10^{-3}$ $M$ for $\mathrm{Mg}^{2+}$. The reaction was inhibited by the intermediates of CoA blosynthesis, of which CoA Itaelf was the most effective inhtbicor. other properties of the enzyme vere also investigated.
\end{abstract}

\section{INTRODUCTION}

Phosphorylation of pantothenic acid, the flrst atep in CoA blosynthesis from pantothentc actd, has been found in microorgantsms $(14,75,97)$ and mammals $(14,15,98,99)$. However, most of the reporta publiahed were based on experiwents with crude or partially purifled preparations. Difficulty in purifying this enzyme may be attributed to the fact that the enzyme is hard to otablItze (99).

In the previous sections, the author has described a novel production method for CoA from pantothenic acid, cystelne, and AKP or ATP wth the bactertum Brevibacterium amoniagenes IFO 12071. Now, the auchor has purified pantothenate kinase from Brevibacterium ammoniagenes as a homogeneous protelo. In this section, procedures for the purtfication of the enzyoe, and some of its characteriatica are described, and 158 phyalological olgnificance in CoA biosyatheals by this bacterium is briefly diecuesed.

\section{MATERIALS AND METHODS}

Chomicals. 4'-Fhogphoptatothento ccid (tr111thium ealt)，4"-phoephopantetheine (calcium Baj.t), $3^{\prime}$-dephospho-
CoA (d11tthium aAlt), and CoA (trilithium alt) vere aynthesized microblologically as described in the previous

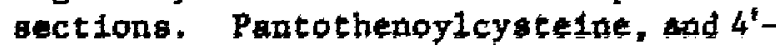
phophopantothenoyloystelne vere kind gifts of Dr. M. Shimizu, Datlchl Setyaku Co., Ltd., Tokyo. Sodium selts of ATP, ADP, GTP, GDP, ITP, UTP, NAD, NADP, and FAD were glven by Kyoua Hakko Kogyo Co:, Ltd, Tokyo. DEAE-cellulose (0.9 meq/g) was given by Ǵreen Cross Corporation, Daske, Sephader G-150 and $G-200$ vere purcheged from Pharmaeta, Uppana. Cytochrome $c$ (horse heart), chywotripeinogen A (bovine pencreas), albumins (egg and bovine serum), alcohol dehydrogenases (yeart and horse Itver), aldolabe (rabbit mubcie), catalabe (begf 1fver), and fertitin vere putchased from Boehringer, Mannheln; and alkaline phosphetase (ealf mucoga)

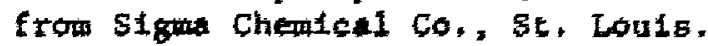
All other reagents vere commereial ptoducta of analytical grade of purity.

Encterial strain and growth conditions, Bravibucterium antionitgenes IFO 12071 wa wed. The becterlin us oultiveted at $28^{\circ} \mathrm{C}$ for $36 \mathrm{ht}$ wdet sheking in a medum tompoged of $10 \mathrm{~g}$ of glucose, 15 of peptone, 3 of $\mathrm{X}_{2} \mathrm{HPO}_{4}, 2 \mathrm{~g}$ of Hacl, $0.2 \mathrm{~g}$ of $\mathrm{Mg}^{5} \mathrm{O}_{4} \cdot 7 \mathrm{H}_{2} \mathrm{O}, 1 \mathrm{~g}$ of yeat 
extract, and 1 21ter of tap water, $\mathrm{pH}$ 7.0. The cells were harvested by centrifugation and washed with $0.01 \mathrm{M}$ potasalum phosphate buffer, pH 7.0. The washed cells were auspended in the same buffer at a concentration of about 25 $\mathrm{mg} / \mathrm{ml}$, and atored at $-15^{\circ} \mathrm{C}$. The average yleld of cells was about 58 (dry welght) per liter of the medium.

Assay of pantothenic acid. The amount of pantothenic acid was measured microblologlcally using Saccharomyces carlsbergensis ATCC 9080 as a test organtem (46).

Assay of pantothenate kinase. A mixture containing 12.5 nmoles of calclum pantothenate, 1.25 umoles of ATP, 0.25 umole of $\mathrm{MgCl}_{2}, 7.5$ umoles of potaseium phosphate buffer, $\mathrm{pH} 6.5$, and the enzyme, in a total volume of 0.25 $\mathrm{ml}$ was 1ncubated at $37^{\circ} \mathrm{C}$ for $5-30 \mathrm{~min}$. The activity of pantothenate kinase was measured as the difference between the amount of pantothenic acid initially present and that the remaining after the reaction. Th1s was checked by measuring the recovery of pantothenic acid after digestion with intestinal alkaline phosphatase. One unit of the activity is defined as the amount of the enzyme which catalyzes the decrease of 1 nmole of pantothenic acid per min under the above conditions. Specific activity is defined as units per mg of proteln.

Polyacrylamide gel electrophoresis. Electrophoresis was performed using a modiffed method of Ornstein and Davis (100) in 7.57 polyacrylamide gel at $4^{\circ} \mathrm{C}$ In Tris-glycine buffer, $\mathrm{pH} 8.3$, with a current of $3 \mathrm{~mA}$ per tube. Instead of preparing space gel, samples dissolved in the reservolr buffer containing 107 sucrose were layered on coarse gel. The position of the protein bands was detected by staining the gel with Amldo Black.

Cellulose acetate electrophoresis. Electrophoresis on cellulose acetate membrane (Carl Schlelcher and Schull, Dasel) was performed at $3 \mathrm{~mA} / 3 \mathrm{~cm}$ (300 v) on cooling plates for $1 \mathrm{hr}$ with 0.01 potasaim phosphate buffer, $\mathrm{pH}$
7.0 , according to the procedure of Kohn (101). The amount of proteln spotted was about $80 \mu g(5 \mu 1)$. The position of the protefn bands was detected by stalning the membrane with Amldo Black.

Estimation of molecular weight by gel filtration. The molecular weight of pantothenate kinase was determined by Sephadex G-200 gel filtration, according to the method of Andrews (102). The colum $(0.9 \times 30 \mathrm{~cm})$ was equilibrated with $0.01 \mathrm{M}$ potassium phosphate buffer, $\mathrm{pH} 7.0$. The elution of the proteins was performed, using the same buffer, at a flow rate of 1 drop per 4-5 min. The proteins used as standards were used in various combinations, usually two at a time, to callbrate the column. The amounts employed for each protein were about $0.1-0.3 \mathrm{mg}$ in a total volume of $0.2 \mathrm{mi}$. Elution volume for both yeast and Ifver alcohol dehydrogenase, catalase, and aldolase were obtaIned by measurement of their catalytic activities as described by Racker (103), Chance and Maehly (104), and Taylor (105), respectively, while those for both egg and serum albumins, chymotrypsinogen A, ferritin, and cytochrome $c$ were determined from the absorption measurement at $280 \mathrm{~nm}$ or $412 \mathrm{~nm}$.

Stoichiometry. A reaction mixture contalning 110 nmoles of calclum pantothenate, $0.19 \mu$ mole of ATP, $0.25 \mu$ mole of $\mathrm{MgCl}_{2}, 7.5$ umoles of potassium phosphate buffer, $\mathrm{pH} 6.5$, and $215 \mu \mathrm{g}$ of the purified enzyme (spectflc activity, 31 nmoles/mg/min) in a total volume of $0.25 \mathrm{ml}$ was incubated for $30 \mathrm{~min}$ at $37^{\circ} \mathrm{C}$. A mixture omitting the enzyme was taken as a control run. The reaction was stopped by boiling the tube for $1 \mathrm{~min}$ and $50 \mu 1$ of the mixture was spotted on Toyo Roshi No.53 filter paper. Compounds were separated by paper chromatography, using as solvent isobutyric actd-0.5 N ammontum hydroxide $(5: 3$, by vol.), and each spot corresponding to ATP and ADP was eluted with $5 \mathrm{ml}$ of $0.1 \mathrm{M} \mathrm{HCl}$. The amounts of ATP and ADP were measured by the absorbance at $260 \mathrm{~nm}$.

Identification of reaction products. Paper chromatography for the identifi- 
cation of reaction products was performed using the following solvents: $I, n-$ butanoi-acetic acld-water $(5: 2: 3$, by vol.); and II, 1sobutyr 1c acid-0.5 N amonium hydroxide $(5: 3$, by yol.). ATP and ADP were located wth a UV-Iamp. Phosphorus-contalning compounds were located with Hanes and Isherwood spray (50) followed by ultraviolet irradiation; sulfhydryl compounds were detected wh Toenntes and Kolb spray (51). For speclal purposes, pantothenate-contalning compounds were detected by the use of bloavtographlc technlques.

Assay of phosphatases. Phosphatase activities in the kinase fraction were checked as follows: $p$-Nitrophenylphosphatase activity was checked by measurIng the p-nttrophenol released (106). Phosphatase against $4^{\prime}$-phosphopentothenic acld was checked by measuring the pantothenic acid released (99), and that against ATP by measuring the ADP and AMP formed using paper chromatography followed by the absorption measurment at $260 \mathrm{~nm}$.

other methods. Protein was determined by the method of Lowery et a1. (107) with egg albumin as a standard. For opectal purposes, the concentration was also determined spectrophotometrically from the absorbance at $280 \mathrm{~nm}$. The absorbance of a solution of $1 \mathrm{mg} / \mathrm{ml}$, determined by the method of Lowry et al. (107) was about 1.15 at $280 \mathrm{~nm}$ in a $1 \mathrm{~cm}$ curette with $0.01 \mathrm{M}$ potassium phosphate buffer, $\mathrm{pH} 7.0$.

\section{RESULTS}

\section{Purification of the enzyme}

Al1 operations were performed at 0 $5^{\circ} \mathrm{C}$ throughout the purification procedures. In these procedures, centrifugation was carrled out at $12,000 \times g$ for $30 \mathrm{mln}$, and potassium phosphate buffer, $\mathrm{pH} 7.0$, was used.

Preparation of crude extract. Frozen cell suspension (about $25 \mathrm{~g}$ as dry matter in $500 \mathrm{ml}$ of $0.01 \mathrm{M}$ buffer) was thawed, disrupted with a Kaljo-Denk1 19 kfiz ultrasonic oscillator for $4 \mathrm{hr}$, centrifuged, and the clear supernatant was obtained.

Ammonium sulfate fractionation. Three lots of the above oupernatant were combined, then the solution was brought to 0.6 saturation by aading solid ammontum sulfate slowly and with stiring. The $\mathrm{pH}$ of the solution was maintalned at 7.0 with $7.5 \mathrm{~N}$ ammonlum hydroxide. After atirring for a further $30 \mathrm{~min}$, the precipitate was collected by centrifugation, and disgolved in $0.01 \mathrm{M}$ buffer. The solution was then dialyzed overnight (16 hr) agalnst two changes of 5 liter volumes of the same buffer.

Chromatography on DEAE-cellulose. The dialyzed solution was applied to a column $(5.5 \times 40 \mathrm{~cm})$ of DEAE-cellulose previously equilibrated with $0.01 \mathrm{M}$ buffer. After washing with 2 liters of $0.02 \mathrm{M}$ buffer, the enzyme was eluted with $0.05 \mathrm{M}$ buffer at a flow rate of about $300 \mathrm{ml} / \mathrm{hr}$. Fractions were collected, and those with an activity greater than 15 unfts per fraction (5 ml) were pooled and concentrated to about 1 ml within 12 hr using a collodion bag (Carl Schlelcher and Schill, Dassel). A typical elution proffle for pantothenate kinase is shown in FIg. 1 .

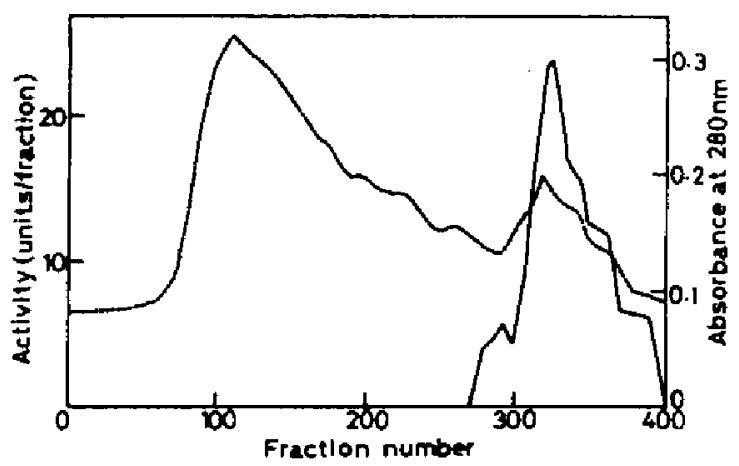

FIG. 1. Profile for the Elution of Protein and Enzyme from the Colum of DEAE-cellulose.

Eech fraction contalns 5 ml of eluate. Detaflo are given la the text. Solid line, enzyme activity; broken line, aboorbance at $280 \mathrm{mom}$.

Chromatography on Sephadex G-150. The concentrated enzyme solution was passed through a colum $(1.8 \times 60 \mathrm{~cm})$ 
of Sephadex G-150 equilibrated with 0.01 M buffer, and the enzyme was eluted th the same buffer at a flow rate of $10 \mathrm{ml} / \mathrm{hr}$. Fractions (Nos, 22-26) wth a speciflc activity of $31-33$ were

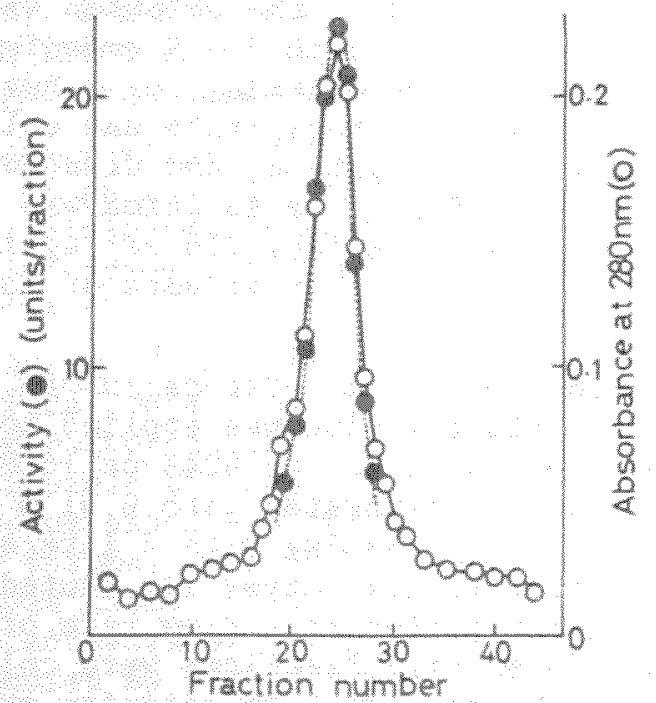

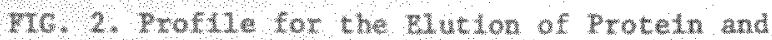
Enzyre from the colum of sephader $6-150$.

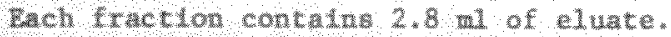
Derall are $8^{1}$ ven 1 n the text

pooled, and concentrated to 1 ml using a collodion bag. A typical elution proflle for the enzyme is shown in Flg. 2.

4 sumary of the ylelds and spectfic activitles of the varlous fractions obtalned during the purlfication procedure 1s giver in Table I. The enzyne has been purifled approximately 200-fold over the crude extract.

TABLE 1, SUMARY OR YTELDS AND SPECIFTC ACTIVITYES OF FRACTIONS OBTAINED DURTNG THE PURTRTCATION OF RANTOTHENATE KINASE FROM BREVT BACTERTUN ANWONTAGERES IRO 12071

\begin{tabular}{|c|c|c|c|}
\hline tractron & $\begin{array}{l}\text { rotal } \\
\text { prots } \\
(\text { ms })\end{array}$ & 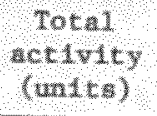 & 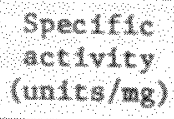 \\
\hline cellextrat & 12305 & 2035 & 0.18 \\
\hline Grmaon 1 uns sul / ate & 8750 & 1488 & 0,17 \\
\hline bELE-col Lulose & 4,5 & 199.4 & 37,55 \\
\hline Sephadex $c-150$ & 2,4 & 82.6 & 34.31 \\
\hline
\end{tabular}

Activities of phosphatases 1 in the cell extract were negliglble in degree, and they were completely separated from the kinase by the chromatography on DEAE-cellulose.

Throughout the purification procedures, rapld operations were required in order to achieve better purification. Usually, the above process was completed within $3-4$ days. Stagnation in the process and further scale-up of the puriflcation brought considerable loss of the activity. In some cases, a scale of one-thind that described above was performed, and good results were obtained.

\section{Properties of the enzyme}

polyacrylamide gel and cellulose acetate membrane electrophoresis. The purlfied enzyme gave a single band on dise gel electrophoresis, while the enzyme preparation whithout gel filtration on Sephadex G-150 showed one major band having the activity and three minor bands (FIg. 3). On cellulose acetate membrane,

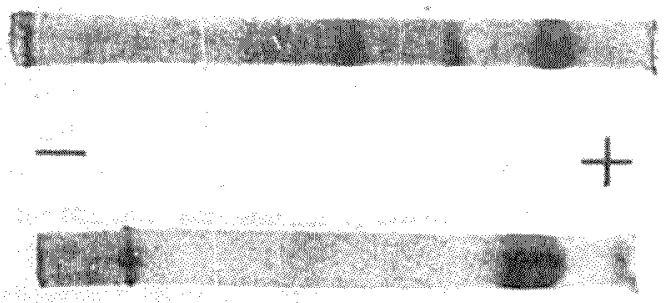

MT. 3. Polyacrylatde Gel. Euectrophoresis of Fantotherate kinas:

Top, before Sephadex G-150 gel filtrton (a) botcon, after sephadex $6-150$ gel flutration (b) The enzyes applied vere about $100 \mathrm{~kg}$ (a) and 150 Ng (b). Detalls are glren in the cext.

both the enzyme preparations gave a single band.

Molecular weight. The molecular weight of pantothenate kinase was determined by the method of Andrews (102) (Fig: 4). from the flgure, a value of approm xlmately 45,000 was calculated. 


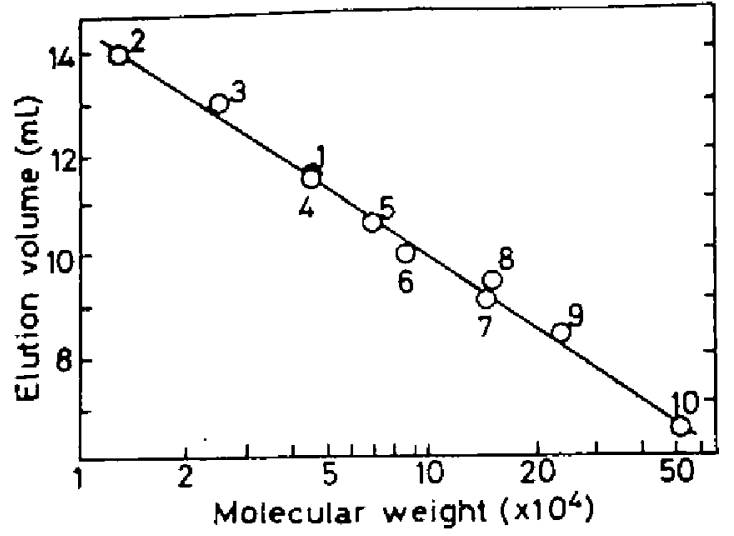

FIG, 4. Estimation of the Molecular Weight of Pantothenate Kinase by Gel Piltracion.

The protelas used were: 1 , pantothenate kinase; 2 , cytochrome $c(13,000) ; 3$, chymotripsinogen A $(25,000) ; 4$, egg albumin $(45,000)$ 5 , serum albumin $(67,000) ; 6,11$ ver alcobol dehydrogenase $(84,000) ; 7$, aldolase $(147,000)$; 8 , yeast alcohol dehydrogenase $(151,000) ; 9$, catalage $(240,000) ; 10$, ferritin $(540,000)$. The amount of pantothenate kinase applied was about $250 \mathrm{\mu g}$, and the activity was detected as described in the text. The nutbered in parenthesis represents the molecular weight of each protein. Detalled condictons are givn in the text.

Absorption spectrum. The absorption spectrum of the enzyme in $0.01 \mathrm{M}$ potassium phosphate buffer, $\mathrm{pH} 7.0$, showed a maximum of absorbance only at $279 \mathrm{~nm}$ whth a small shoulder at $285-290 \mathrm{~nm}$. A solution of $1 \mathrm{mg}$ enzyme per $\mathrm{ml}$ in a $1 \mathrm{~cm}$ cuvette exhlbited an absorbance of 1.04 at $280 \mathrm{~nm}$.

stability. The purifled pantothenate kinase was considerably unstable at $4^{\circ} \mathrm{C}$ at a protein concentration of $2 \mathrm{mg}$ per ml of $0.01 \mathrm{M}$ potassium phosphate buffer, $p H 7.0$, and lost all of 1 ts activity within 4 days. The enzyme after the DEAE-cellulose step was also Inactivated completely within a week. ATP and sucrose, which stabllize the kinase of rat liver (99), were ineffective. The purifled enzyme (12.2 $\mathrm{gg}$ in $5 \mu 1$ of $0.01 \mathrm{M}$ potaralum phosphate buffer, $\mathrm{pH}$ 7.0) was incubated at various temperatures for $10 \mathrm{mln}$, and the remaining act1vity was measured. All the Intial activity remained below $30^{\circ} \mathrm{C}$, but $70 \%$ of the initial activity was lost at $37^{\circ} \mathrm{C}$, and at $43^{\circ} \mathrm{C}$ the enzywe was completely inactivated. The enzyme (12.2 $\mu \mathrm{g}$ in 50 $\mu 1$ of $0.01 \mathrm{M}$ potasetum phosphate buffer) was stable at $\mathrm{pH} 7.0$ when Incubated at $30^{\circ} \mathrm{C}$ for $10 \mathrm{~m} 1 \mathrm{n}$, but $50 \mathrm{z}, 10 \mathrm{z}$, and $20 \%$ of the initial activity was loat at $\mathrm{pH}$ $6.5,7.5$, and 8.0 , respectively.

Substrate specificity. The enzyme catalyzed not only the phosphorylation of pantothenic acid, but also. that of pantothenoylcysteine, pantetheine (panthethine plus cystelne), and pantothenyl alcohol. The products of phosphorylatlon of pantothenic acld, pantothenoylcyatelne, pantetheine, and pantothenyl alcohol were Identical with $4^{\prime}$-phosphopentothenlc acid (Rf 0.59 in solvent I), 4'-phosphopantothenoylcysteine (Rf 0.42 in solvent I), 4'-phosphopantetheine (Rf 0.66 in solvent $I$ ), and phosphopantothenyl alcohol* (Rf 0.38 in solvent I), respectively.

Nucleotide requirement. Phosphorylation of pantothenic acid by the enzyre was completely dependent on ATP and $\mathrm{Mg}^{2+}$. ATP could be substituted for, part1y, by ITP, GTP, and UTP. However, CTP was ineffective under the conditions employed (Table II).

\section{TABLE II. NUCLEOTIDE SPECIFICITY OF PANTOTHPALTE RTNASE}

The enzyme (12.2 ug; spectific activity, $34.3 \mathrm{nmoles} / \mathrm{mg} / \mathrm{min}$ ) was incubated at $37^{\circ} \mathrm{C}$ for 15 in with 12.5 moles of calcium pantothenate, 0.25 wole of $\mathrm{MgCl}_{2}, 7.5$ umoles of potasofum phosphate buffer, $\mathrm{pH} 6.5$, and 1.25 moles of mucleoside triphosphate as indicated. Detaila are given in the text.

\begin{tabular}{cc}
\hline Rucleot Ide & Relative activity \\
\hline ATP & 100 \\
ITP & 46 \\
GTP & 28 \\
UTP & 18 \\
GTP & 0 \\
Rone & 0 \\
\hline
\end{tabular}

* This was prepared microblologically from pantothenyl alcohol according to a similar procedure to that for the preparation of $4^{\prime}$-phosphopantothenlc acld as described in Section VI. 
Effect of divalent metal lons. The enzyme required $\mathrm{Mg}^{2+}$ for the activity. $\mathrm{KnSO}_{4}, \mathrm{CoCl}_{2}, \mathrm{NICl}_{2}$, and $\mathrm{ZnCl}_{2}$ were $82 \mathrm{x}$, $767,55 \%$, and $52 \%$ as effective, respectively, as $\mathrm{MgCl}_{2}, \mathrm{CaCl}_{2}, \mathrm{CdCl}_{2}, \mathrm{BaCl}_{2}$, $\mathrm{PbCl}_{2}, \mathrm{FeSO}_{4}$, and $\mathrm{CuSO}_{4}$ were Ineffective. The phosphoryaltion of pantothenic acid was inhibited by the additions $\left(10^{-3} \mathrm{M}\right)$ of $\mathrm{BaCl}_{2}, \mathrm{PbCl}_{2}, \mathrm{FeSO}_{4}$, and $\mathrm{CuSO}_{4}$. The activities obtained with these cations were $56 \%, 537,9 \%$, and $3 \%$ of that of the complete system $\left(\mathrm{MgCl}_{2}\right.$ only), respectively. $\mathrm{MnSO}_{4}, \mathrm{CoCl}_{2}, \mathrm{NiCl}_{2}, \mathrm{ZnCl}_{2}$, $\mathrm{CaCl}_{2}$, and $\mathrm{CdCl}_{2}$ showed no inhibitory effect.

stoichiometry. When calclum pantothenate and ATP were incubated with the enzyme, 68 nmoles of pantothentc acid and 75 nmoles of ATP were consumed, and 70 nmoles of ADP were formed. The pantothenlc acid was completely recovered by phosphatase digestion.

It appeared that the reaction proceeded most rapldly toward the formation of 4'-phosphopantothentc acid, since no evidence for reveraibility could be obtained on incubation of small amounts of $4^{\prime}$-phosphopantothentc acld with ADP.

Inhibition by the intermediates of CoA biosynthesis and their related compounds. As shown in Table III, CoA and 1ts blosynthet lc precursors inhibited the phosphorylation of pantothenic actd, and CoA, especially, was a very effective 1nhtbitor. Such Inhibitions were also observed in the experiments with rat 1iver pantothenate kinsse (98, 99). Inhibitions by these compounds seemed to be uncompetitive with pantothenic acid, according to the double reciprocal plots. The apparent $K i$ values for these compounds are also given in Table III. Pantothenoylcysteine, pantetheine, and pantotheny1 alcohol, wh1ch were posalble substrates for the kinase as described above, also inhtbited the phosphorylation of pantothenlc acid competitively. The apparent $K i$ values for pantothenoylcystelne, pantetheine, and pantothenyl alcohol were $0.31 \mathrm{mM}, 0.20 \mathrm{mM}$, and $0.095 \mathrm{mM}$, respectively. $3^{\prime}, 5^{\prime}-\mathrm{ADP}, \mathrm{ADP}, 3^{\prime}$-AMP, AMP, GTP, GDP, ITP, UTP, CTP, NAD, NADP,
IABLE III. INHIBITORY EFPECT OF INTERMEDUTES OP COA BIOSYNTHESIS ON THE PHOSPHORYLATION OF PANTOTHENATE

The enzype (12.2 ug; speciflc activity 4. 3 moles/mg/min) vas incubated for $25 \mathrm{~min}$ ith vartous concentrations of intermediates echer conditions are given in the text.

Por obtalning the $X i$ values, the enzyme

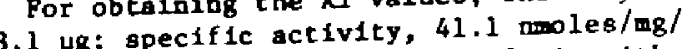
(8.1 Us; speciflc activity $37^{\circ} \mathrm{C}$ for $15 \mathrm{~min}$ with an) ras lncubated antothenate, ranging from various awounts of pantothensce, and absence of the interwediates. The amounts of the of the linteraediaces. ald were as follow: 12.5 aroles of $4^{\prime}$-phosphopantothenic ac1d, 6.25 moles of $4^{\prime}$-phosphopantetheine, 6.25 nmoles of 3'-dephospho-COA, 6.25 moles of COASH, and 3.13 noles of CoASSCOA.

\begin{tabular}{|c|c|c|c|c|}
\hline Intermed fate & \multicolumn{3}{|c|}{ Inh1bit1on (z) at } & $\begin{array}{c}K_{i} \\
(\mu \mathrm{H})\end{array}$ \\
\hline 4'-Phospho- & 18.8 & 8.8 & 3.8 & 125 \\
\hline $\begin{array}{l}4^{\prime}-\text { Phosphopanto- } \\
\text { thenoylcysteine }\end{array}$ & $-a)$ & 6.3 & 0 & - \\
\hline 4'-Phoepho- & 60.1 & 33.0 & 2.1 & 37 \\
\hline $\begin{array}{l}\text { 3' -Dephospho-CoA } \\
\text { CoASH } \\
\text { CoASSCoA }\end{array}$ & $\begin{array}{l}42.5 \\
68.8 \\
42.5\end{array}$ & $\begin{array}{l}18.8 \\
50.0 \\
23.8\end{array}$ & $\begin{array}{l}2.5 \\
2.5 \\
8.8\end{array}$ & $\begin{array}{l}83 \\
33 \\
67\end{array}$ \\
\hline
\end{tabular}

a) not exanined.

b) An equivalent amount to that of CoAsa was added.

and FAD showed no inhibitory effect at a concentration of $1 \mathrm{mM}$.

Kinetics. The $\mathrm{pH}$ optimum and the temperature optimum for the kinase reaction were found to be 6.5-7.0, and $30-37^{\circ} \mathrm{C}$, respectively.

Double reciprocal plots of the reaction velocity versus varying concentrations of one substrate and a flxed concentration of the other substrate gave apparent $\mathrm{Km}$ values of $0.067 \mathrm{mM}$ for pantothentc acid (Vmax, $61.6 \mathrm{nmoles} / \mathrm{mg}$ / $\mathrm{min}), 0.035 \mathrm{mM}$ for ATP, and $1.0 \mathrm{mM}$ for $\mathrm{Mg}^{2+}$. A $\mathrm{Km}$ value for the ATP-Mg ${ }^{2+} 1: 1$ mixture was $1.0 \mathrm{mM}$. Substrate inhibition was observed with respect to pantothenic acid at concentrations above $0.5 \mathrm{mM}$.

Effect of inhibitors. The enzyme $(12.2 \mathrm{\mu g}$ ) was not 1nactivated by $1 \mathrm{mM}$ monolodoacetate, $1 \mathrm{mM} p$-chloromercurtc 
benzoate, $1 \mathrm{mH} \alpha, a^{\prime}-\mathrm{d} 1$ pyr $1 \mathrm{dy} 1,1 \mathrm{mM}$ c1trate, and $10 \mathrm{mM} \mathrm{KCN}$, when incubated In $100 \mu 1$ of $0.015 \mathrm{M}$ potassium phosphate buffer, $\mathrm{pH} 6.5$, at $10^{\circ} \mathrm{C}$ for $15 \mathrm{~min}$. While the presence of $1 \mathrm{mM}$ EDTA, $0.1 \mathrm{mM}$ $\mathrm{HgCl}_{2}, 0.1 \mathrm{mM} \mathrm{Na} \mathrm{HAsO}_{4}$, and $1 \mathrm{mM} \mathrm{AlCl} 3$ decreased the orfginal act1vity by $83 \%$, $100 \%, 77 \%$, and $91 \%$, respectively.

Ammontum ion also inhibited the reaction. $\mathrm{NH}_{4} \mathrm{Cl}$ at $0.1 \mathrm{mM}, 1 \mathrm{mM}$, and 10 $\mathrm{mM}$ inhibited the activity by $22 \%, 35 \%$, and $50 \%$, while $\left(\mathrm{NH}_{4}\right)_{2} \mathrm{SO}_{4}$ at $0.05 \mathrm{mM}, 0.5$ $\mathrm{mM}$, and $5 \mathrm{mM}$ inhibited it by $17 \%, 40 \%$, and $66 \%$, respectively.

\section{DISCUSSION}

This section describes the purtification and properties of the pantothenate kInase of Brevibacterium ammoniagenes IFO 12071. The enzyme was purtfied as a homogeneous protein with a spectific activity of more than 30 nmoles/mg/min from the cell extract of the bacterium. Experiments with the purified enzyme showed that the enzyme catalyzes the formation of $4^{\prime}$-phosphopantothenic acid and ADP from pantothentc acid and ATP in the presence of $\mathrm{Mg}^{2+}$.

Cel1 extract of Brevibacterium ammoniagenes is a much richer source of pantothenate kinase than liver extracts used by Karasawa et a1. (98) and by Ablko et al. $(15,99)$. It seems probably that phosphatase activities are very week in this bacterium. Possibly this initial advantage is reflected also in gatning preparations of pantothenate kinase of much higher spectelc activity than those reported by Abtko et al. (99) for liver pantothenate kinase.

Although bacterial pantothenate kinase and liver pantothenate kinase are broadly similar, their properties difier In detal1. Both the enzymes are ofmilar in that both phosphorylate not only pantothentc acld but also pantothenoylcyateine, pantethefne, and pantothenyl alcohol, and that the reaction is inhibited by CoA and its blosynthetic intermediates. Both the enzymes are considerably unstable. The liver enzyme was relatively stable in the presence of $1 \mathrm{mM} \mathrm{ATP}$ and $10 \%$ sucrose. However, these compounds sere ineffective for the bacterlal enzyme. Difficulty in purifying the enzywe way be attributed to the fact that the enzyme is hard to atabllize. In the present case, with increasing purtty a decrease in stability was brought about. The purifled enzyme was Inactivated very rapidly even at $4^{\circ} \mathrm{C}$. The loss of the activity was apparently Irreversible.

As previously described, incubation of pantothenic ac1d, cysteine, and ATP with dried cells of Brevibacterium anmoniagenes gave CoA in high yields.

Further, cultivation of the bacterium wth pantothenic acid, cystelne, AMP, and a surfactant gave a higher accumulation of $\mathrm{COA}(2-5.5 \mathrm{mg} / \mathrm{ml})$, and that with UMP and CMP replacing AMP gave an accumulation of $4^{\prime}$-phosphopantetheine, but not $\operatorname{CoA}$, in the culture broth. The author initlated the present investigation in order to clear up the mechanism of this higher accumulation of CoA by the bacterium. Unexpectedly, it was observed in the bacterium as well as in rat 11ver, that phosphorylation of pantothenic acid, the first step in CoA biosynthes1s, was strongly Inhibited by CoA as the end product. Karasawa et al. (98) and Abiko et al. (99) have suggested that the inhibition of the kinase by CoA may be involved in regulating the CoA level in rat liver. The physiological significance of this inhibition may be appreclated from the standpoint of the control of CoA biosynthesis. However, the overproduction of CoA by the bacterium and this regulation mechanism in the bacterium seem to contradict each other. In this connection, further detafled investigation would be required. Another interesting property of the enzyme is its partia. lack of spectflctty with regard to the nucleotide. Accumulation of $4^{\prime}$-phosphopantetheine, but not CoA, from pantothenic acid, cysteine, UMP, and CMP by the bacterlum may be attributed to this broad speciflcity of the nucleotide for the phosphorylation of pantothenic actd (see Section VII). 
Section IX.

\begin{abstract}
Some Aspects of the Enzyme Activities Involved in Coenzyme A Biosynthesis in Various Microorganismsk)
\end{abstract}

The distribution of the enzyme activities relating to CoA biosyathes1s from pantothenic acid in various microorganisws and the effect of CoA on these activitles are described.

High activitles of partial reactions involved in CoA biosyntheals were surveyed in varlous type culture strains involving bacteria, actinomycetes, lactic acid bacterla, molds, and yeasts. Generally, higher activities were found in bacterla. CoA inhlbited the phosphorylation of pantothenic acid, and resulted in a decrease of CoA production in all the CoA productng strains, while only a little Inhibition by CoA was observed in the other reactions, and CoA production frow $4^{\prime}$-phosphopantothenlc acld by Brevibacterium ammoniagenes IFO 12071 was not repressed even in the presence of $4 \mathrm{mM}$ of CoA. Extracellular excretion of the enzymes of CoA biogynthests was observed when cells were in contact with sodium laurylsulfate. Degrading activity ageinst $C o A$ and that against AMP were relatively lower in CoA producing strains when compared with those in other strains. It was confirmed that Brown's route of CoA blosynthesis operates in Brevibacterium ammoniagenes IFO 12071.

\section{INTRODUCTION}

In the previous sections, the author has described a higher production of CoA from pantothentc acid, cystelne, and AMP or ATP by Brevibacterium ammoniagenes IFO 12071, and has established a new process for the production of CoA. Purther, Including CoA 1tself, all the intermediates of COA blosynthesis from pentothenlc acld, though $4^{\prime}$-phosphopantothenoylcyatelne is an exception, have been synthestzed freely with highyields by the microbial process.

This section describes some aspects of the enzyme activities relating to CoA blosynthesis from the viewpolnt of higher accumulation of COA.

\section{MATERIALS AND METHODS}

Chemicals. Pantothenoylcyatelne and 4 '-phosphopantothenoylcysteine were the kind gifts of Dr. M. Shimizu, Dafich1 Selyaku Co., Ltd., Tokyo. All other reagents used were the same as those in the preceding section.

Microorganisus and cultivations. Br- evibacterium ammoniagenes IFO 12071 and other strains used were strains preserved in the laboratory of Applied Microbiology, Department of Agricultural Chemlstry, Kyoto Unlveraity. The medla for bacteria and yeasta were the same as described in Section I. Molds were grown in a medium composed of $3 \mathrm{~g}$ of sucrose, $0.3 \mathrm{~g}$ of yeast extract, $0.2 \mathrm{~g}$ of $\mathrm{NaNO}_{3}, 0.05 \mathrm{~g}$ of $\mathrm{MgSO}_{4} \cdot 7 \mathrm{H}_{2} \mathrm{O}, 0.05 \mathrm{~g}$ of $\mathrm{KCl}, 0.01 \mathrm{~g}$ of $\mathrm{FeSO}_{4} \cdot 7 \mathrm{H}_{2} \mathrm{O}$, and 100 $\mathrm{ml}$ of tap water, $\mathrm{pH} 6.2$. Actinomycetes were grown in a medium composed of 18 of peptone, $0.1 \mathrm{~g}$ of meat extract, 0.1 8 of yeast extract, $0.5 \mathrm{~g}$ of $\mathrm{NaCl}$, and $100 \mathrm{ml}$ of tap water, $\mathrm{pH} 7.0$. Lactic acld bacteria were grown in a medium composed of $I g$ of glucose, 18 of peptone, 18 of yeast extract, 18 of sodIum acetate, $0.05 \mathrm{~g}$ of $\mathrm{KH}_{2} \mathrm{PO}_{4}, 0.05 \mathrm{~g}$ of $\mathrm{K}_{2} \mathrm{HPO}_{4}, 0.02 \mathrm{~g}$ of $\mathrm{MgSO}_{4} \cdot 7 \mathrm{H}_{2} \mathrm{O}, 0.001$ 8 of $\mathrm{FeSO}_{4} \cdot 7 \mathrm{H}_{2} \mathrm{O}, 0.001 \mathrm{~g}$ of $\mathrm{HnSO}_{4} \cdot 4-6$ $\mathrm{H}_{2} \mathrm{O}, 0.001 \mathrm{~g}$ of $\mathrm{NaCl}$, and $100 \mathrm{ml}$ of tap water, $\mathrm{pH} 7.0$. All the cultivations were carrled out with shaking for $2-4$ days at $28^{\circ} \mathrm{C}$, except for lactic acid bacteria, which were cultured without shaking. 
Preparation of dried cells. Dried cells of vartous microorgantams were prepared according to the method described previously (see Section I).

Preparation of cell extract. Enzyme extraction was carried out as follows: (A) Washed cells of Brevibacterium anmoniagenes IFO 12071 (700 mg as dry matter) were suspended $1 \mathrm{n} 20 \mathrm{ml}$ of $0.01 \mathrm{M}$ potassium phosphate buffer, $\mathrm{pH} 7.0$, containing 0.037 2-mercaptoethanul, d1srupted by a Kalfo-Denki. $19 \mathrm{kHz}$ ultrasonic oscillator for 10 min below $10^{\circ} \mathrm{C}$, and centrifuged. The supernatant was dialyzed overnight against 2 I1ter volumes of the same buffer at $4^{\circ} \mathrm{C}$, which was then diluted to a protein concentration of $6.6 \mathrm{mg}$ per $\mathrm{ml}$ with the same buffer and used as the enzyme. (B) The wasined cells (700 mg as dry matter), 14 mg of sodium laurylgulfate, and 350 umoles of potassium phosphate buffer, $\mathrm{pH} 7.0$ were Incubated for 1 hr at $20^{\circ} \mathrm{C}$ In a total volume of $7 \mathrm{ml}$, and the cells were removed by centrifugation. The supernatant was used as the enzyme.

Reactions and activity measurements. The reaction mixture for the synthesis of CoA from pantothenic acid contained, in $0.5 \mathrm{ml}$, 1 umole of sodium pantothenate, 2 umoles of cysteine, 5 pmoles of ATP, 75 umoles of potassium phosphate buffer, $\mathrm{pH} 6.5,5$ umoles of $\mathrm{MgSO}_{4}, 0.5$ mg of sodlum laurylsulfate, and $50 \mathrm{mg}$ of dried cella. The activity was measured by measuring CoA formed with the phosphotransacetylase method of Stadtman et al. (43) using the enzyme of Escherichia coli Crookes AKU 0001 as described previously (see Section I). The mixture, with cystelne omltted, was used for the phosphorylation of pantothenlc acid. The activity was measured by following the disappearance of pantothenlc acld with Saccharomyces carlsbergensis ATCC 9080 (46). This was checked by measuring the recovery of pantothenic acid after digestion with alkaline phosphatase (calf intestinal mucosa). The reaction m1xture for the coupling reaction between $4^{t}$-phosphopantothenic acid and cysteine contained, in $0.5 \mathrm{ml}, 1$ umole of $4^{\prime}$-phosphopanto- thenlc ac1d, 2 umoles of cyotelne, 5 umoles of CTP or ATP, 5 umoles of $\mathrm{MgSO}_{4}$, 75 umoles of potasalum phosphate buffer, $\mathrm{pH} 6.5,0.5 \mathrm{mg}$ of sodium lauryloulfate, and $50 \mathrm{mg}$ of dried cells. The activity was measured as the difference between the amount of $4^{\prime}$-phosphopantothenic acid inftially present and that remaining after the reaction. The reaction $\mathrm{mix}-$ ture for the synthesis of CoA from 4'phosphopantethelne contained, in $0.5 \mathrm{ml}$, 1 umole of $4^{\prime}$-phosphopantethe1ne, 5 wmoles of ATP, 5 umoles of $\mathrm{MgSO}_{4}, 75$ umoles of potasolum phosphate buffer, $\mathrm{pH} 6.5,0.5 \mathrm{mg}$ of sodium laurylsulfate, and $50 \mathrm{mg}$ of dried cells. A mixture in which 4'-phosphopantetheine was replaced with an equimolar amount of $3^{\prime}-$ dephospho-CoA was used for the syntheals of CoA from $3^{\prime}$-dephospho-CoA. Both the activities were measured by measuring the CoA formed. The assay mixture for CoA degrading activity contained,

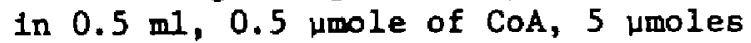
of $\mathrm{MgSO}_{4}, 75$ umoles of potassium phosphate buffer, $\mathrm{pH} 6.5,0.5 \mathrm{mg}$ of sodium lauryloulfate, and $30 \mathrm{mg}$ of dried cells, and the activity was measured by followIng the disappearance of CoA in the reaction mixture. The assay mixture for AMP degrading activity contalned, in $0.5 \mathrm{ml}, 5$ umoles of AMP, 5 umoles of $\mathrm{KgSO}_{4}, 75 \mu$ moles of potasstum phosphate buffer, pH $6.5,0.5 \mathrm{mg}$ of sodium laurylsulfate, and $50 \mathrm{mg}$ of drled cells. The activity was checked by measuring the AMP remalning, using paper chromatography followed by absorption messurement at $260 \mathrm{~nm}$. The solvent used was 18obutyric ac1d-0.5 N ammonium hydroxide0.1 M EDTA (100:60:1.6, by vol.). In all the cases, the reaction was carried out at $37^{\circ} \mathrm{C}$ in a total volume of $0.5 \mathrm{ml}$, and terminated by 1mmeraing the tube in bolling water for $5 \mathrm{~min}$. After $1.5 \mathrm{ml}$ of water was added, cells were removed by centrifugation. The supernatant was employed in the determination of the substrate remaining or the product formed.

other method. Protein was determined by the method of Lowry et aI. (107). 


\section{RESULTS}

Distribution of the enzyme activities relating to CoA biosynthesis in various microorganisms and the effect of COA on the activities

In Section I, 1t has been shown that Brovibacterium ammoniagenes IFO 12071 and several bacterla are able to synthesize CoA from pantothenic acid, cystelne, and ATP with high ylelds. In the present experiment, higher activities of the partial reactions involved In CoA biosynthesis were surveyed in further varleties of mlcroorganisma, which involved 29 atrains of bacteria, 22 strains of actinomycetes, 21 strains of lactic actd bacteria, 15 stratns of molds, and 31 strains of yeasts. High activities for the phosphorylation of pantothenic acid were found in 12 strains of bacteria, 2 strains of actinomycetes, and 1 strain of mold, by which more than $40 \%$ of the pantothenic acid added was phosphorylated. Wide distribution of the coupling activity between $4^{\prime}$-phosphopantothenic acid and cysteine was found. In 22 strains of bacteria, 6 strains of actinomycetes, 5 strains of lactic acid bacteria, and 2 strains of molds, more than 407 of the $4^{\prime}$-phosphopantothentc actd added coupled wth cysteine in the presence of CTP. CTP was a more preferential energy source than ATP in almost all the strains tested, as pointed out by Brown (14) In Proteus morganii. But, Bacillus megaterium NI 8100 and BacilIus subtilis IFO 3007 showed a higher activity with ATP than with CTP. Eleven strains of bacteria, 2 strains of actinomycetes, 2 strains of lactic acid bacterla, and 1 strain of mold produced CoA from $4^{\prime}$-phosphopantetheine with more than $40 \%$ yield. Thirteen strafns of bacterla, 3 strains of actinomycetes, 2 strains of lactic acid bacterla, and 2 strains of molds converted more than $40 \%$ of the $3^{\prime}$-dephospho-CoA added to CoA. Among them, 2 stralns of Brevibacterium ammoniagenes IFO 12071 and IFO 12072 , and Corynebacterium glutamicum ATCC 13060 gave an almost quantitative conversion of $3^{\prime}$-dephospho-CoA

TABLE I. ACTIVITIES OF THE ENZYMES INVOLVED IN COA BIOSYNTHESIS IN SEVERAL. MICROORGANISMS AND THE EFFECT OF COA

All the reactions were carried out for $4 \mathrm{hr}$ with or without CoA. Other conditions are as umole of the product The amount of CoA supplemented was 0.5 mole. Activitles are given The activities with coA in

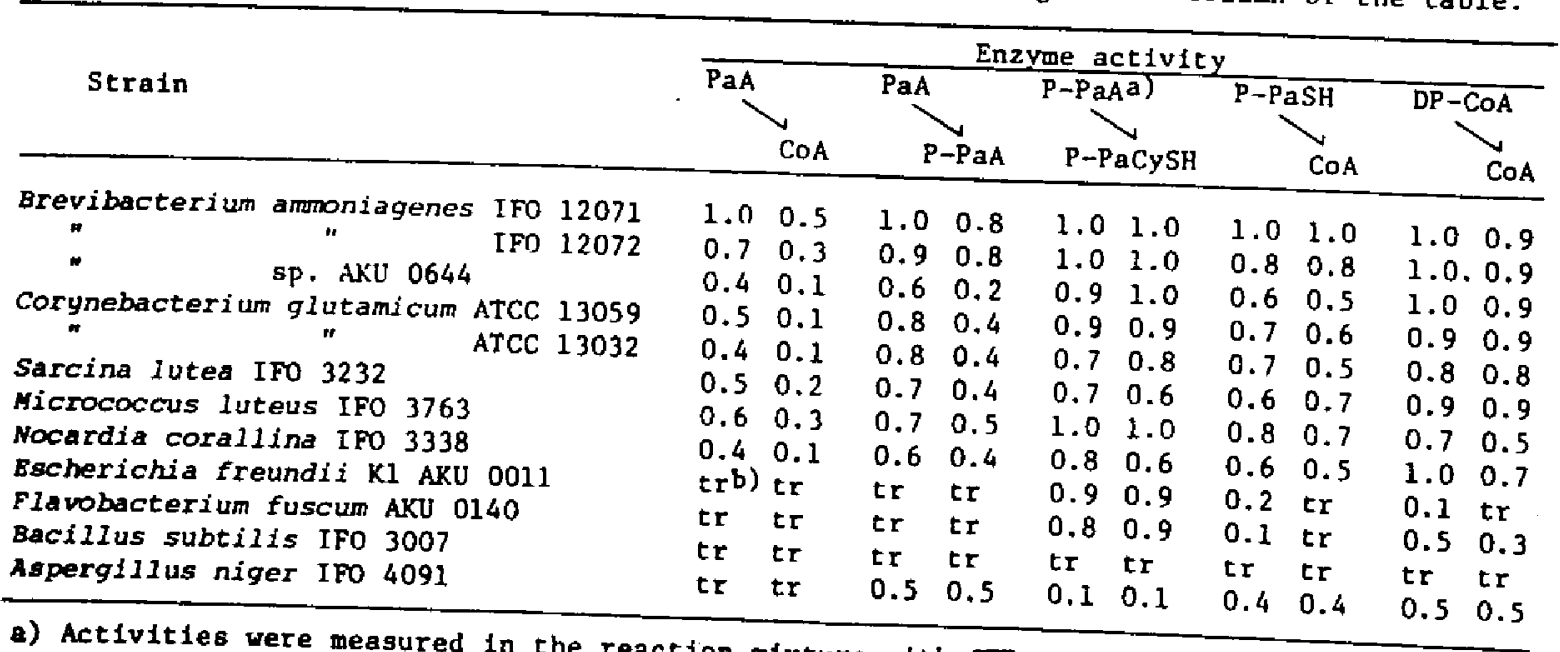

b) tr: trace.

Abbreviactons used: PaA, pantothen1c acid; P-PaA, 4'-phosphopantothenic ac1d; P-PaCySH,
$4^{\prime}$-phosphopantothenoylcysteine; P-PaSH, 4'-phosphopantetherno; 
to CoA up to a concentration of $8 \mathrm{mH}$. As to the over all reaction to produce CoA from pantothenic acid, cysteine, and ATP, higher activities were shown by 8 strains of bacterla and 1 strain of actinomycete, which accumulated COA at a concentration of more than $0.5 \mathrm{mg}$ per ml. A part of the results is shown in Table I. Table I also shows the effect of CoA on the activities of the enzymes lnvolved in CoA blosynthesis in severai microorganisms. CoA inhibited the phosphorylation of pantothenic acid, and resulted in the decrease of CoA production in all the strains tested, while no signiffcant inhibition was observed In the formation of CoA from $4^{\prime}$-phosphopantethelne and from 3'-dephospho-CoA, and in the coupling between $4^{\prime}$-phosphopantothenic actd and cysteine. DegradIng activity against CoA and that against AMP were relatively lower in CoA producing strains when compared with those in other strains, as shown in Table II.

TABLE II. COA- AND AMP-DEGRADING ACTIVITIES IN SEVERAL MICROORGANISMS

The reaction was carried out as described in the text. Activities are given as umoles of the substrate degraded in 0.5 ml of the reaction mixture

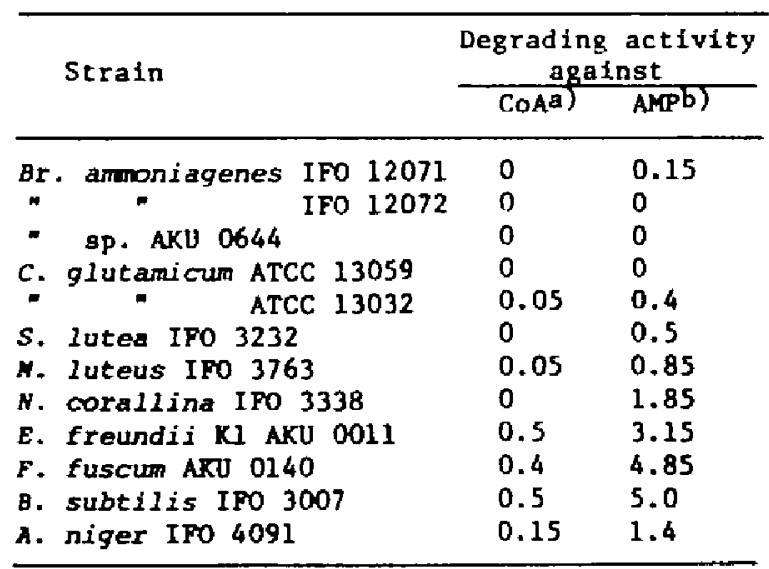

a) The reaction time was $2 \mathrm{hr}$,

b) The reaction cime was $3 \mathrm{hr}$.

Activities for the phosphorylation of pantothenic acid and the accumulation of $C O A$ in the culture broth were teated, using several CoA producing stratns. The strains were adapted to the fermen-
TABLE III. PHOSPHORYLATION OF PANTOTHENIC ACID AND ACCUMULATION CF COA IN THE CULTURE BROTH BY SEVERAL BACTERIA

All the culcivations were carried out as described previously (aee Section IV.), except that cyateine was omitted in the case of the phosphorylation of pantothenic acid yielding

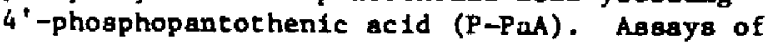
CoA and P-PaA were made for 6 day cultures. Growth was checked for 3 day cultures.

\begin{tabular}{|c|c|c|c|c|}
\hline \multirow{2}{*}{\multicolumn{2}{|c|}{ Strain }} & \multicolumn{2}{|c|}{$\begin{array}{l}\text { Product } \\
\text { formeda) }\end{array}$} & \multirow[t]{2}{*}{ Growthb) } \\
\hline & & $\mathrm{P}-\mathrm{PaA}$ & $\operatorname{ccs}$ & \\
\hline \multirow{4}{*}{\multicolumn{2}{|c|}{ 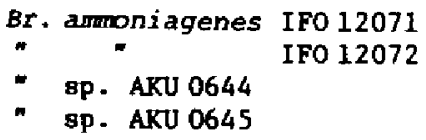 }} & 2.0 & 3.3 & 0.71 \\
\hline & & 1.4 & 1.0 & 0.64 \\
\hline & & 1.7 & 0.8 & 0.65 \\
\hline & & 1.0 & 0.3 & 0.69 \\
\hline \multirow{2}{*}{\multicolumn{2}{|c|}{$\begin{array}{c}\text { C. glutamicum ATCC } 13059 \\
\text { " ATCC } 13060\end{array}$}} & 0.9 & 0.1 & 0.54 \\
\hline & CC 13060 & 1.2 & 0.4 & 0.57 \\
\hline \multirow{2}{*}{\multicolumn{2}{|c|}{ s. Iutea Ifo 3232}} & 0.4 & 0.1 & 0.41 \\
\hline & & 0.8 & 0.1 & 0.60 \\
\hline \multicolumn{2}{|l|}{ H. Luteus IP0 3763} & 0.1 & 0 & 0.35 \\
\hline
\end{tabular}

a) Values are given as mg per $\mathrm{ml}$. The amount of P-PaA formed is given as pantothenic acid consumed.

b) A half ml of broth was diluted to $50 \mathrm{ml}$, and the turbidity at $610 \mathrm{~nm}$ was read. Growth check was made only in the case of CoA formation.

tation medium used for CoA production by Brevibacterium ammoniagenes IFO 12071 by repeated single colony selections, and cultivated in the fermentation medIum as described previously (see Section IV). Brevibacterium ammoniagenes IFO 12072 and Brevibacterium sp. AKU 0644 gave CoA accumulation (Table III).

Effect of CoA concentration on the accumulation of COA

It has been previously observed that a purifled pantothenate klnase of Brevibacterium ammoniagenes IFO 12071, as we11 as that of rat liver $(98,99)$, is strongly inhibited by CoA as the end product (see Section VIII). As shown in Fig. 1, a CoA dependent inhibition of the phosphorylation of pantothenic acid was also observed in a system with dried cells of this bacterium, while only a little inhibition was observed in the coupling between $4^{\prime}$-phosphopantothenic acid and cystelne and that between $4^{\prime}$-phosphopantethelne and ATP, 


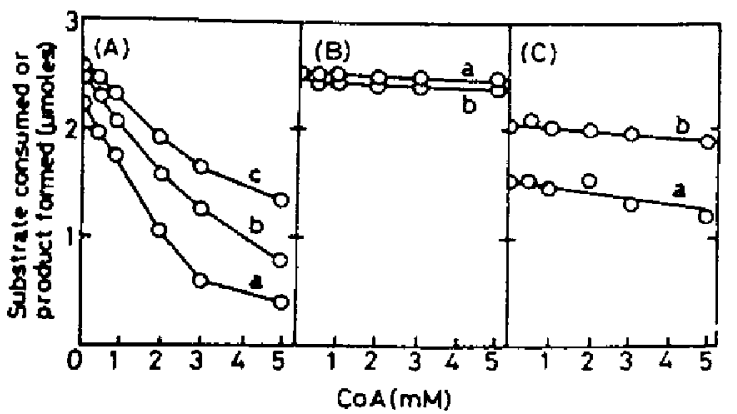

FIG. 1. Rffect of CoA Concentration on the Reactiong Involved in CoA Blosynthesis.

(A) Phosphorylation of pantothenic ac1d: The reaction was carried out for $3 \mathrm{hr}$ (a), $5.5 \mathrm{hr}$ (b), or $8 \mathrm{hr}$ (c) with or without COA as ind1cated. Other conditions were the same as those described in the text except that the pantothenic actd and ATP added were 2.5 and 7.5 woles, respectively.

(B) Coupling of $4^{\prime}$-phosphopantothenic acid with cystelne in the presence of CTP (a) or ATP (b): The reaction was carried out for 5.5 hr with or without $C O A$ as indicated. Other conditlons were the same as those described in the text except that the $4^{1}$-phosphopantothentc acid, cysteine, and CTP (or ATP) added were $2.5,5$, and 7.5 umoles, respectively.

(C) Conversion of 4'-phosphopantetheine to CoA: The reaction was carried out for $3 \mathrm{hr}$ (a) and $5.5 \mathrm{hr}$ (b) with or without CoA as indicated. Other conditions were the same as those described in the text except that the " ' phosphopantetheine and ATP added vere 2.5 and 7.5 jmoles, respectively.

even when $5 \mathrm{mM}$ of $C O A$ were present in the reaction mixture. The CoA synthesis from pantothenic actd was almost completely repressed when $4 \mathrm{mM}$ of $\mathrm{COA}$ were present. This inhibition could be partly overcome by increasing the concentration of the dried cells. On the other hand, the synthesis from 4'-phosphopantothenic acid was not repressed significantly, even when $4 \mathrm{mM}$ of COA were present (FIg. 2).

Stability of the enzyme activities involved in COA biosynthesis

The enzyme activities of CoA blosynthesis in dried cells of Brevibacterium ammoniagenes IFO 12071 were considerably atable when stored at $-15^{\circ} \mathrm{C}$, and 108 of the activities was within $16 \%$ after 3 years storage (Table IV). Similar results were obtained with the

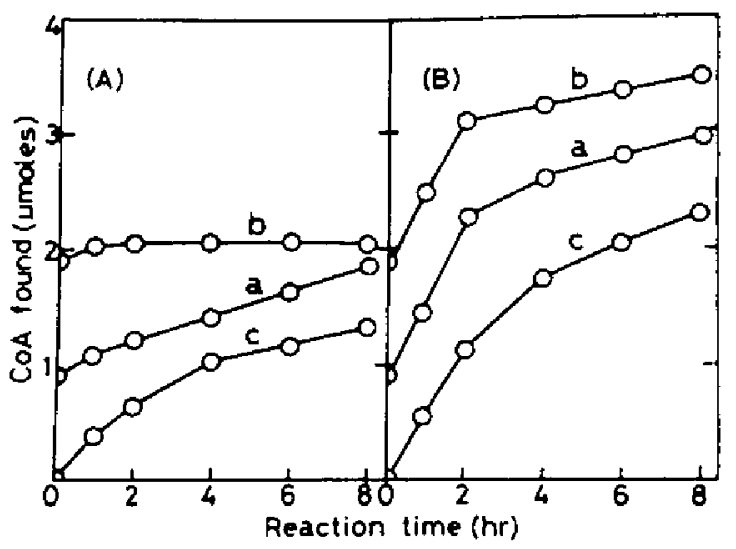

PIG. 2. Tise Courge for the Synthesis of CoA in the Presence of COA.

(A) Synthesis from pantothenic acid: The reaction was carried out uth 1 pmole (a) or 2 umoles (b) of CoA. Other conditions were the same as those described in the text except that the pantothenic acid, cyateine, and ATP added were $2.5,5$, and 7.5 umoles, respective1y. The mixture without CoA was uged as a control run (c).

(B) Syuthesis frow 4'-phosphopantothenic acid: The reaction was carrled out with 1 umole (a) or 2 umoles (b) of CoA. Other conditions vere the same as those described in the text except that the 4'-phosphopantothenic ac1d, cystelne, and ATP added were 2.5, 5 , and 7.5 moles, respectively. The mixture without CoA was used as a control run (c).

experiment with washed cells.

Effect of surfactant on the enzyme activities involved in COA biosynthesis

The author has previously observed the great stimulation of $\mathrm{COA}$ accumulation by the addition of certain surfactants (see Section II, III, and IV). As shown in Table $V$, extracellular excretion of the enzymes of CoA biosynthesis was observed, when the washed cells of Brevibacterium ammoniagenes IFO 12071 were treated with sodium laurylsulfate. However, the proteins which leaked out were a very small amount when compared with that in cells which were treated with ultrasonic oscllation, and substantial activity remained in the cells. The dlalyzed cell extract contained activities of pantothenate kinase, $4^{\circ}$-phosphopantothenoylcyateine synthetase, $4^{+}$-phosphopantothenoylcysteine decarboxylase, $3^{\prime}$-de- 
TABLE IV. EFFECT OF STORAGE TIRE ON THE ENZYE ACTIVITIES OF COA BIOSYNTHESIS IN DRIED CELLS

The reaction for the phosphorylation of pantothenic acid ( $P a A$ ) was carried out for 5 hr as described in the text, except that PaA and ATP added vere in the amounts of 2.5 and 7.5 umoles, respectively. The reaction for the coupling of $4^{\prime}$-phosphopantothenic actd (P-PaA) with cyoteine ylelding 4'-phosphopantothenoylcystelne (P-PaCysH) vas carried out for $3 \mathrm{hr}$ as described in the text, except that the P-PaA, cysteine, CTP, and dried cells added were $2.5,5,7.5$ umoles, and $30 \mathrm{mg}$, respectively. The reaction for the syathesis of CoA from PaA was carried out for $5 \mathrm{hr}$ as described in the text, except that the PaA, cysteine, and ATP added were $2.5,5$, and 7.5 umoles, zespectively.

\begin{tabular}{cccc}
\hline \multirow{2}{*}{$\begin{array}{c}\text { Storage time } \\
\text { (year) }\end{array}$} & \multicolumn{1}{c}{ Activity remaining } & $(\boldsymbol{z})$ \\
\cline { 2 - 4 } & PaA & P-PaA & PaA \\
\hline 0 & 100 & $-8)$ & 100 \\
1 & 95 & 100 & 97 \\
2 & 90 & 100 & 100 \\
3 & 88 & 100 & 84 \\
\hline
\end{tabular}

a) not tegted.

phospho-CoA pyrophosphorylase, and $3^{\prime}-$ dephospho-CoA kinase, which are necessary for the operation of Brown's pathway of CoA biosynthests, but pantothenolysysteine decarboxylase activity, which converts pantothenoylcysteine to pantethelne, could not be detected.

\section{DISCUSSION}

In 1954 Levintow and Novel1i (12) and Hoagland and Novelli (13) proposed a pathway for the blosynthesis of $\mathrm{CoA}$ in antmals, in which pantothentc acid couples with cystelne to yleld pantothenoylcysteine as the first step, followed by decarboxylation to pantetheine, which $1 \mathrm{~s}$ then phosphorylated to form 4'-phosphopantethefne, and they suggested that the pathway is as follows: pantothenic actd $\longrightarrow$ pantothenoylcysteine $\longrightarrow$ pantethelne $\longrightarrow 4^{\prime}$-phosphopantetheine $\longrightarrow$ $3^{\prime}$-dephospho-CoA $\rightarrow$ CoA. In 1959, However, Brown (14) proposed an alternatIve pathway using rat liver, rat kidney, and Proteus morganit, in which pantothenic acid is first phosphorylated to
TABLE $\nabla$. ENZYTE ACTIVITIES OF COA BIOSYTTHESIS ARD THEIR LEAKAGE FROM THE CHLLS BY SURPACTANT TREATHETT

Euzyme extraction ras carrled out as described in the text. Twenty-five moles of each substrate were lncubated for $30 \mathrm{~min}$ at $37^{\circ} \mathrm{C}$ wth 2.5 unoles of ATP, 0.25 umole of $\mathrm{HgCl}_{2}, 15$ umoles of potasalim phosphate buffer $\mathrm{pH} 7.0$, and $0.225 \mathrm{ml}$ of the supernatant as the enzyme in a total volume of $0.25 \mathrm{ml}$, except as Indicated in the footnotes. The reaction was cerminated by bolling the tube for $1 \mathrm{mln}$ and the mixture was employed in the determination of the substrate or the product. Activities are given as moles of the substrate consumed or the product formed per $30 \mathrm{~min}$.

\begin{tabular}{|c|c|c|c|}
\hline \multirow{2}{*}{$\begin{array}{l}\text { Enzyme } \\
\text { and } \\
\text { reaction }\end{array}$} & \multicolumn{3}{|c|}{ Activity extracted by } \\
\hline & $\begin{array}{l}\text { ultrasonfc } \\
\text { oscillation }\end{array}$ & SLS & buffer ${ }^{d)}$ \\
\hline $\begin{array}{l}\text { PaA kinase } \\
(\mathrm{PaA} \longrightarrow \mathrm{P}-\mathrm{PaA})\end{array}$ & 15.5 & 4 & 0 \\
\hline $\begin{array}{l}\text { P-PaCySH syathetase } \\
(\mathrm{P}-\mathrm{PaA} \longrightarrow \mathrm{P}-\mathrm{PaCySH})\end{array}$ & 25 & 14.5 & 4 \\
\hline $\begin{array}{l}\text { P-PaCySH } \\
\text { decarboxylase } \\
(\mathrm{P}-\mathrm{PaCySH} \longrightarrow \mathrm{P}-\mathrm{PaSH})\end{array}$ & 25 & -e) & - \\
\hline $\begin{array}{l}\text { DP-CoA Pyro- } \\
\text { phosphorylase and } \\
\text { DP-CoA kinase } \\
\text { (P-PaSH } \longrightarrow \text { CoA) }\end{array}$ & 17.5 & 7 & 0 \\
\hline $\begin{array}{l}\mathrm{DP}-\mathrm{COA} \text { kinase } \\
(\mathrm{DP}-\mathrm{COA} \longrightarrow \mathrm{COA})\end{array}$ & 19 & 6.5 & 1.5 \\
\hline $\begin{array}{l}\text { PaCySH decarboxylase } \\
\text { (PaCySH } \longrightarrow \text { PaSH) }\end{array}$ & $e^{c)}$ & - & - \\
\hline
\end{tabular}

a) A half umole of cysteine was supplemented and ATP was replaced by an equimolar amount of CTP.

b) ATP was onitted. The activity was checked by measuring the P-Pash formed by Lactobacillus buIgaricus Bl (94) after digesttng the sample with alkaline phosphatase.

c) ATP was omitted. The activity was checked by the same method as described in the footnote b).

d) The extraction condftions were the same as those wth SLS except for onttting SLS.

e) not tested.

Abbreviation used: PaCySH, pantothenoy1cyateine; PaSH, pantetheine; SLS, sodiun laurylsulfate. Other abbreviationg used here are the game as those in Table I.

yield 4'-phosphopantothenic acid prior to coupling with cysteine, and concluded that the pathway is as follows: pantothenic acid $\longrightarrow 4^{\prime}$-phosphopantothenic acid $\longrightarrow 4^{\prime}$-phosphopanto thenoylcysteine $\longrightarrow 4^{\prime}$-phosphopant etheine $\rightarrow 3$-dephospho$\mathrm{COA} \rightarrow \mathrm{CoA}$. He also suggested that in 
many syatema it is the only operative route. Later, Ablko $(15,16)$ and AbIko et al. (17) revalued these two routes in detall, and confirmed that Brown's route operates in rat 11 ver.

The studies deacribed in the preceding sectlons and the present studies showed that a CoA produclng stratn, Brvibacterium amoniagenes IFO 12071, $1 \mathrm{~s}$ able to accumulate $4^{\prime}$-phosphopantothenic actd and 4'-phosphopantethelne, which are the 1ntermediates of Brown's route, and contains all the enzymes, pantothenate kInase, 4'-phosphopantothenoylcystelne synthetase, and $4^{\prime}$-phosphopantothenoylcystelne decarboxylase, necessary for the operation of this route. These observations suggest that Brown's route operates in this bacterium. Another result which supports this conclusion is that no pantothenoylcysteine decarboxylase activity could be detected in the bacterium. It is considered that Brown's route also operates in a wide varlety of microorganlsms because many of those tested contalned at least one or two of the enzyme activities involved only in this route.

It was observed in many microorganIans tested, as well as In Brevibacterium ammoniagenes IFO 12071 (see Section VIII) and in rat liver $(98,99)$, that phosphorylation of pantothenic acid was strongly inhibited by $\mathrm{CaA}$ as the end product. This suggests that a feedback inhibition of pantothenate k1nase by CoA may be involved in regulatIng the Intracellular CoA level as a general regulation mechanism. And 1ts occurrence In wide distribution suggests that it may play a signiflcant role in the control of $\operatorname{COA}$ blosynthesis. However, the presence of this inhibition mechantom is considered an undesirble feature for obtalning CoA in a high yield. Possibly this disadvantage 18 reflected in the difficulty in obtaining a much higher accumulation of COA than that the author previously attained (3-5 $\mathrm{mg}$ pe ml, see Section IV).

Some device to avold it may be posatble: Derfvation of a mutant lacking the control mechan $1 \mathrm{sm}$ or development of a method for the spectific removal of the product from the synthesizing system may bring a much higher accumulation of CoA. The interesting finding presented In this section 18 that the other enzymes involved in CoA blosynthesis were less sensitive against CoA. The higher accumulation of COA from 4'-phosphopantothenlc acld and cystelne in the presence of $C O A$ may be attributed to this less-sensitiveness of the enzymes. This route for syathesizing CoA 18 probably one of the avallable routea for avolding the feedback Inhibition.

Another Interesting finding is that all the CoA producing strains possess considerably low degrading activities againgt CoA and AMP. Th1s seems to be one of the 1mprotant features necessary for the production of CoA. Probably this may be partly reflected in the synthesizing activities of $\mathrm{CoA}$ as ind cated in Table $I$.

The removal of permeability barriers of the cells was confirmed by the leakage of the enzymes of CoA blosynthesis from the cells upon the addition of a surfactant. This suggests that CoA synthesis occurs partly extracellularly.

A high stability of the drted cells seems to give an advantage for its practical use as an enzyme source for the production of COA. 


\title{
CHAPTER II. \\ DEGRADATION OF PANTOTHENYL ALCOHOL \\ BY MICROORGANISMS ${ }^{\text {l) }}$
}

\begin{abstract}
Several microorgantsms 1solated from soll were found to grow in the medium containing pantotheny1 alcohol. The results of the investigation of the degradative metaboliam of this compound demonstrated that there are two different inducible pathways.

The experiments with strain 1041 showed that 3-aminopropanol appeared in the early stage of culture, and $\beta$-alanine in the stationary phase of growth without accumulation of pantothentc acid. 3Amlnopropanol plus pantoate, as well as pantothenyl alcohol, supported the growth of the induced culture. Rapld hydrolysis of pantothenyl alcohol was produced by Incubating with either washed cells or cell extract of this bacterium grown on pantothenyl alcohol, while no oxidation of this substrate to pantothenic acid was observed. When 3-aminopropanol was incubated with the washed cells or cell extract, only $\beta$-alanine was a major product. Isolation and identification of the products were performed. These results led to the conclusion that pantothenyl alcohol is hydrolyzed to pantoic acId and 3-aminopropanol as the first step, whIch is then followed by oxidation to B-alanine.

Strain 1091 produced pentothenic acid, but not 3-aminopropanol, from pantothenyl alcohol. B-Alanine plus pantoate, as well as pantothenyl alcohol, supported the growth of the induced culture, while 3-aminopropanol plus pantoate did not support it. No degradation of 3-aminopropanol was observed. Isolation and 1dentification of pantothentc acid and a 3-methyl-2-benzothlazolone hydrazone dertvative of the aldehyde from pantothenyl alcohol were performed. From the results, it was confirmed that pantothenyl alcohol is first oxidized to pantothenic acid, which is then hydrolyzed to $B$-alanine and pantolc acid.

Pantothenyl alcohol was also oxidized to pantothenic acid by Bacillus roseus AKU 0208. The eazyme was not induced in the presence of pantothenyl alcohol.
\end{abstract}

\section{INTRODUCTION}

It has been reported that pantothenyl alcohol, an alcohol analog corresponding to pantothenic acid, is a growth inhibitor of some pantothenic acid-requiring bacteris $(39,40)$, although it has a pantothenic acid-1ike activity in mamals $(36-38,108-111)$. Ab1ko et al. (110) invest Igated the metabolism of this compound using rats and demonstrated its oxidative conversion to pantothentc acld by liver alcohol dehydrogenase. However, 11ttle is known of the metabo- 11sm of this alcohol in microorganisms. It seems, therefore, to be interesting to know the microblal response of this antimetabolite. Th1s chapter describes some aspects of the degradation of pantothenyl alcohol by mferoorganisms.

\section{MATERIALS AND METHODS}

Chemicals. Potassium D-pantoate was prepared according to the method of Stansly and Schlosser (112). Potassium pantothenate was prepared from the calclum salt according to the procedure of 
Goodhue and Snell (113). Other chemlcals were from comercial sources.

Media. The baral toedlum was composed of $0.05 \mathrm{~g}$ of $\mathrm{K}_{2} \mathrm{HPO}_{4}, 0.05 \mathrm{~g}$ of $\mathrm{MgSO}_{4}{ }^{\circ}$ $7 \mathrm{H}_{2} \mathrm{O}, 1 \mathrm{ml}$ of $\mathrm{vitamin}$ solution containing, per liter, $1 \mathrm{mg}$ of thiamine-HCl, $1 \mathrm{mg}$ of riboflavin, $1 \mathrm{mg}$ of nicotinic ac1d, $0.2 \mathrm{mg}$ of $p$-aminobenzolc acld, $0.01 \mathrm{mg}$ of follc actd, and $0.01 \mathrm{mg}$ of blot1n, and $99 \mathrm{ml}$ of water. It was adJuated to pH $6.8-7.0$ with KOH and sterilized by autoclaving at $120^{\circ} \mathrm{C}$ for 10 min. The pantothengl alcohol medium was prepared by adding a concentrated, filter-aterilized solution of D-pantothenyl alcohol to the sterilized basal medlum to supply $0.5 \mathrm{~g}$ per $100 \mathrm{ml}$. Pantothenyl alcohol-agar was prepared by solidifylng pantothenyl alcohol medlum with 27 agar. The medium used for the ocreening of the strains accumulatIng pantothenic acid from pantothenyl alcohol was composed of $0.5 \mathrm{~g}$ of peptone, $0.5 \mathrm{~g}$ of meat extract, $0.05 \mathrm{~g}$ of yeast extract, $0.2 \mathrm{~g}$ of $\mathrm{NaCl}$, and $100 \mathrm{ml}$ of water. For yeasts the medium supplemented with $2 \mathrm{~g}$ of glucose was also used. The $p H$ of the medium was adjusted to 6.8-7.0 for bacterla and actinomycetes, and to 5.5-6.0 for yeasts and molds. After autoclaving at $120^{\circ} \mathrm{C}$ for $15 \mathrm{mln}$, f1lter-gter $111 \mathrm{zed}$ D-pantothenyl alcohol was added to supply $0.02 \mathrm{~g}$ per $100 \mathrm{ml}$.

Isolation of pantothenyl alcohol degrading strains. After the enrictment cultures on pantothenyl alcohol medium for three times, the cultures were atreaked on pantothenyl alcohol-agar plates. Colonies of distinctly different appearance were plcked Into the 11quid pantothenyl alcohol medium. These plat Ing and shaking processes were each repeated 3 times, and 14 apparently different strains were obtalned. Stock cultures were maintalned by culturing for 4 days at $28^{\circ} \mathrm{C}$ on pantotheny 1 alcohol-agar stants, then storing at $5^{\circ} \mathrm{C}$ for 1.5 months. In the studies described hereln stra1ns 1041 and 1091 were malnly ured.

Culture frocedures. For small scale experimente, cultures in $5 \mathrm{ml}$ of 11quid medium contained in $16.5 \times 160 \mathrm{~mm}$ test tubes were grown from 27 (by vol.) 1noculum at $28^{\circ} \mathrm{C}$ on a reciprocal shaker (Iwashiya, RTR-1), which was set for 240 rpm with a tube angle of $20^{\circ}$. Larger volumes ( $100 \mathrm{ml}$ or $500 \mathrm{ml}$ ) were grown in 0.5 liter or 2 liter volume of shakIng flasks on a reciprocal shaker (Iwash1ya, RLR-5), which was set for 120 osclilations per min with an amplitude of $7 \mathrm{~cm}$. Growth was measured turb1dimetrically at $610 \mathrm{~nm}$, and cell yleld was determlned by means of a culture relatIng absorbance to dry cell welght.

screening for pantothenic acid accumulating strains. Type culture stralns preserved in the Laboratory of Applied Microblology, Department of Agricultural Chemlstry, Kyoto Unlversity, and the 1solates utilizing pantothenyl alcohol were grown in the medium described above for 2 days at $28^{\circ} \mathrm{C}$ on a reciprocal shaker. After boiling the tube, the pantothenic acid in the broth was assayed.

Preparation of washed cell suspensions. Usually the cells of the exponential phase of growth were harvested by centrifugation, washed twice with $0.85 \% \mathrm{NaCl}$, suspended in $0.01 \mathrm{M}$ potassium phosphate buffer, $\mathrm{pH} 7.0$, and stored at $0^{\circ} \mathrm{C}$ unt 11 used.

Preparation of cell extracts. Twenty-five $m l$ of each cell suspenston, containing approximately $300 \mathrm{mg}$ of cells (dry we1ght) per ml, were disrupted with a Kaffo-Denkt $19 \mathrm{kHz}$ ultrasonic obcillator for $10 \mathrm{~min}$ below $10^{\circ} \mathrm{C}$ and clarified by centrifugation at $12,000 \mathrm{x}$ $g$ for $15 \mathrm{~min}$ at $0^{\circ} \mathrm{C}$, and the supernatant (protein concentration, 10-30 mg/ml) was dialyzed overn1ght agatnst two changes of 2 11ter volumes of $0.01 \mathrm{M}$ potassium phosphate buffer, $\mathrm{pH} 7.0$.

chromatographies and electrophoresis. Paper chromatography (PPC) was carried out by the ascending technique on Toyo Roshl No.53 paper. The solvent systems used were: I, $n$-butanol-acetlc acidwater $(5: 2: 3$, by vol.); II, 1sobutyrlc acid-0.5 $\mathrm{N}$ ammonium hydroxide $(5: 3$, by vol.); and III, n-propano1-28\% ammontum 
hydroxide-water $(6: 3: 1$, by vol.). Th1n layer chromatography (TLC) on Eastman Chromagram Sheet 6065 was carried out using the following solvents: $I, n$-butanol-acetic acid-water $(5: 2: 3$, by vol.); II, 997 ethanol-water $(6: 4$, by vol.); and III, methanol-n-butanol ( $3: 1$, by vol.). Paper electrophoresis (PEP) was carried out on Toyo Roshi No.53 paper Impregnated with $0.02 \mathrm{M}$ acetate buffer, $\mathrm{pH} 3.5$ at $0.5 \mathrm{~mA} / 3 \mathrm{~cm}$ ( 500 volts) for 60 min. 3-Aminopropanol, B-alanine, and other amtno actds were detected by ninhydrin ( $0.25 \%$ in acetone) spray. B-Alantne was also detected by bioautographic techniques using saccharomyces carlsbergensis ATCC 9080 (46). Pantolc acid and other nonvolatile acids were detected by sugar-an1line reagent (114) in the earlier experiments. Pantothenyl alcohol was detected by bloautographic techniques using Leuconostoc mesenteroides P-60 ATCC $8042(115,116)$, and pantothenic acid with Saccharomyces car1sbergensis ATCC 9080 (46) or Lactobacillus plantarum ATCC 8014 (45).

Determination of pantothenyl alcohol. Pantothenyl alcohol was separated by the electrophoretic method described above, eluted from the paper, and determined microbiologically with Leuconostoc mesenteroides P-60 ATCC 8042 (115, 116).

Determination of 3-aminopropanol and B-alanine. 3-Aminopropanol or B-alantne was separated by PPC with solvent $I$. The correspond Ing ninhydrin-reactive zones were cut out, and the color was extracted wth methanol and estimated by reading the absorption at $600 \mathrm{~nm}$ agafnst similarly treated standards of 3-aminopropanol or B-alanine. B-Alanine was also determined microblologically with Saccharomyces carlsbergensis ATCC 9080 (46) after separating by PPC and eluting from the paper.

Assay of pantothenyl alcohol cleaving activity. The cleaving activity was determined routinely by measuring the disappearance of pantothenyl alcohol in the reaction mixture. Thts was checked by measuring the 3-amtnopropanol formed. The reaction mixture contained 0.5 umole of pantotheny1 alcohol, 25 umoles of

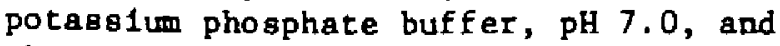
the appropriately diluted enzyme in a total volume of $0.5 \mathrm{ml}$. The mixture was incubated at $37^{\circ} \mathrm{C}$ for $20-60 \mathrm{~min}$ and the reaction was terminated by boilfng the tube for $1 \mathrm{~min}$.

Assay of pantothenyl alcohol oxidizing activity. The oxldizing activity was determined routinely by measuring the pantothenlc acid formed. The reaction conditions were the same as those for the assay of pantothenyl alcohol cleaving activity. For spectal purposes, the aldehyde (pantothenyl aldehyde?) formed was measured by the 3-methyl-2benzothtazolone hydrazone (MBTH) method of Sawick1 et aI. (117).

Assay of 3-aminopropanol oxidizing activity. The activity was determined routinely by measuring the B-alanine formed. The reaction system used was the same as described above except that pantothenyl alcohol was replaced with an equimolar amount of 3-aminopropanol.

Assay of pantothenic acid cleaving activity. The activity was determined by measuring the disappearance of pantothenic acid in the reaction mixture

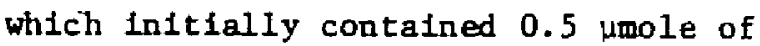
potassium pantothenate. Other conditlons were the same as those for the assay of pantothenyl alcohol cleaving activity.

Other methods. Pantothenic acld was determined microbiologically by Lactobacillus plantarum ATCC 8014 (45), for which pantolc acid, pantolactone, and B-alanine are Inactive. Pantothenyl alcohol did not inhibit for the growth of this organism under the conditions employed here. Pantolc actd was determined according to the method of Nurmikko et al. (118).. Proteln was measured by the method of Lowry et al. (107). Sulfur contents of the MBTH derivatives were determined by the Schoninger combuation method (119). NMR spectra were measured on a Varian A-60 spectrometer at $60 \mathrm{MHz}$ or a Hitach1 Perkin-Elmer R-22 spectrometer at $90 \mathrm{MHz}$ in $\mathrm{D}_{2} \mathrm{O}$ with DSS as an 1nternal standard. 


\section{RESULTS}

Studies with isolated strains

Characterization of cultures. Culture 1041 was Gram-negative rod (0.5$0.8 \times 2-3 \mu)$, oxidat Ive In Hugh and Le1faon' thed 1um (120), and Kovacs ${ }^{1}$ oxidase (121) positive, and produced diffusible fluoreacent pigments. On pantothenyl alcohol-agar it formed yellow, gliatenIng, and sooth colonies. Culture 1091 was al so Gram-negative rod $(0.5-0.8 \times$ 1-2 $\mu$ ), oxldative in Hugh and Lelf on $^{\prime} \mathrm{s}$ medium (120), and Kovacs' oxidase (121) posttive. It produced diffusible redbrown plgments on K1ng's A medium (122), but no fluorescence on KIng ' $\mathrm{B}$ B medium (122). On pantothenyl alcoho1-agar it formed cream-colored and glistening colontes. Both the strains are presumably placed in the genus Pseudomonas.

Growth response of the isolated strains to pantothenyl alcohol and its related compounds. The comparative

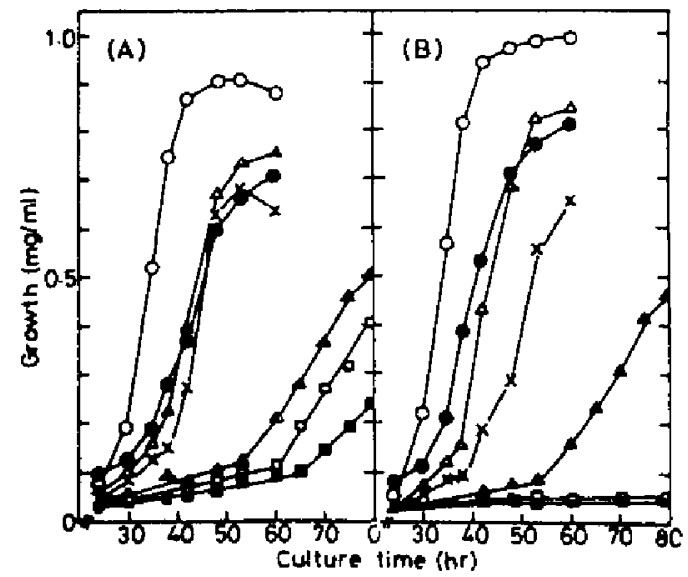

FIG. 1. Growth Response of the Isolated Strains on Pantothenyl Alcohol and its Related Compounds.

Strain 1041 (A) and strain 1091 (B) vere cultivated in $500 \mathrm{ml}$ shaking flasks containing $100 \mathrm{ml}$ of each medium as indicated below. Growth curves vere obtained in the basal medIum plus: 1 , pantothengl alcohol (25 mM): 0 , potasaim pantothenate ( $25 \mathrm{mM}) ; \Delta$, potassium pantoate (25 mM) plus B-alanine (25 mM) : A, potassium pantoate $(25 \mathrm{EM})$ plus $\mathrm{NH}_{4} \mathrm{Cl}$ (25 mM); $X$, B-alanine $(25 \mathrm{mH}) ; 0$, potassium pantoate (25 -m) plus 3-aminopropenol (25 m*); 1 , 3andoopropanol (25 mM). All cultures vere inoculated wth $4 \mathrm{mg}$ (dry velght) of waghed cells grown in pantothenyl alcohol mediun. Other conditions are given in the text. growth rates of strain 1041 and those of atrain 1091 on pantothenyl alcohol and 1ts nydrolyzed and oxidized products are shown in $\mathrm{P} 1 \mathrm{~g}$. 1 . In both strains, growth with pantothenate was alightly superior to that with equimolar amounts of pantothenyl alcohol itgelf. Both grew well with pantoate plus $\beta$-alanine, B-alanine, or pantoate plus $\mathrm{NH}_{4} \mathrm{Cl}$, as carbon and nitrogen source. Strain 1041 also grew with pantoate plus 3-aminopropanol or with 3-amfnopropanol alone, but these were not utilized by strain 1091 during the time studfed here (144 hr). The growth patterns of other atrains isolated were similar to that of strain 1091.

Metabolic products formed from pantothenyl alcohol by strain 1041. Fifty ul of the filtrate from a culture of strain 1041 grown on pantothenyl alcohol medium were spotted on Toyo Roshi No.53 paper, wich was then developed with elther solvent I or II. After drying the papera, the products were detected by the methods described in the text. A prominent ninhydrin-reactive zone corresponding in position to 3-aminopropanol appeared when the filtrate from 35 hr culture was applied. When the filtrate from 50 hr culture was applied, however, two prominent ninhydrin-reactive zones appeared. One of them, corresponding in position to $\beta-a l a n i n e$, was active in enhancing the growth of Saccharomyces carlsbergensis ATCC 9080 (Rf 0.50 and 0.65 , respectively, in solvents $I$ and $I I)$, and the other, corresponding in postition to 3-aminopropanol, was Inactive ( $R f \quad 0.61$ and 0.77 , respectively, In solvents $I$ and II). However, no detectable mounts of pantothenic acid were found.

The cells harvested from pantothenyl alcohol med lum during the early logar ithmic phase of grourth( $40 \mathrm{hr}$ ) rapldly cleaved pantothenyl alcohol to yield pantolc acld and 3-aminopropanol. 3-Aminopropanol was 1solated through the followIng procedures: A mixture, containing 1.2 mmoles of pantothenyl alcohol, 2 moles of potassium phosphate buffer, $\mathrm{pH} 7.0$, and $200 \mathrm{mg}$ (dry welght) of washed cells from the early logarithmic 
phase of growth $(40 \mathrm{hr})$ in a total volume of $40 \mathrm{ml}$, was shaken for $18 \mathrm{hr}$ at $28^{\circ} \mathrm{C}$, botled for $3 \mathrm{~min}$, and centrifuged. The oupernatant was applied to a column of Dowex $50 \mathrm{~W} \times 8\left(\mathrm{H}^{+}\right.$form, $\left.1.8 \times 20 \mathrm{~cm}\right)$. After washing the column with $0.01 \mathrm{M}$ $\mathrm{HCl}, 3-a m i n o p r o p a n o l$ was eluted with 0.15 $\mathrm{M} \mathrm{HCl}$. Appropriate fractions were collected, treated with Dowex $1 \times 2\left(^{-} \mathrm{OH}^{-}\right)$, adjusted to $\mathrm{pH} 3.0$ with HCl, concentrated to small volume, and lyophilized (yleld, $35 \mathrm{mg} ;$ PPC, Rf $0.60,0.79$, and 0.73 , respectively, in solvents $I, I I$, and III; TLC, Rf 0.63 and 0.78 , respectively, in solvents I and II; PEP, migration towards the cathode, $11 \mathrm{~cm}$; NMR at $90 \mathrm{MHz}$, $(\delta \mathrm{ppm}): 1.63(2 \mathrm{H}, \mathrm{p}, J=3.5 \mathrm{~Hz}), 2.64$ $(2 \mathrm{H}, t), 3.61(2 \mathrm{H}, \mathrm{t}))$. Formation of pantolc acid was demonstrated by the ferrlc hydroxamate spray (118) (PPC, Rf 0.52 in solvent I). Pantothenate, as well as pantothenyl alcohol, was also cleaved by the same cells. Cells of the same organism, grown with either 3-aminopropanol plus pantoate, or with pantothenate, did not cleave pantothenyl alcohol. The cells from glucose plus $\mathrm{NH}_{4} \mathrm{Cl}$ medium were also inactive in cleaving this substrate. When 3-aminopropanol was 1ncubated with the cells grown for $50 \mathrm{hr}$ with pantothenyl alcohol, B-alanine was produced. The product was isolated through the followIng procedures: A mixture, containing 1.2 moles of 3-aminopropanol, 2 moles of potassium phosphate buffer, $\mathrm{pH} 7.0$, and $200 \mathrm{mg}$ (dry weight) of the washed cells in a total volume of $40 \mathrm{ml}$, was shaken for $22 \mathrm{hr}$ at $28^{\circ} \mathrm{C}$, bolled for 3 min, and centrifuged. The supernatant was passed through a column of Dowex $50 \mathrm{w} \times 8\left(\mathrm{H}^{+}\right.$form, $\left.1,6 \times 20 \mathrm{~cm}\right)$. After washing the column with $0.01 \mathrm{M} \mathrm{HCl}$, the passings and washings were combined and passed through a column of Dowex $1 \times 2$ (chloride form, $1.6 \times 20 \mathrm{~cm}$ ), whtch was then washed with $0.01 \mathrm{M} \mathrm{HCl}$. Appropriate fractions contalaing B-alanine were pooled and concentrated, and B-alanine was crystallized from ethanol (yield, $38 \mathrm{mg}$; PPC, Rf 0.53, 0.65 , and 0.52 , respectively, In solvents I, II, and III; TLC, Rf 0.63 and 0.62 , respectively, in solvents I and II; PEP, migration towards cathode,
$-0.5 \mathrm{~cm}$; NMR at $90 \mathrm{MHz}$ ( $\delta \mathrm{ppm}): 2.54$ $(2 \mathrm{H}, \mathrm{t}), 3.18(2 \mathrm{H}, \mathrm{t}))$.

When dialyzed crude extract from the cells grown with pantothenyl alcohol was Incubated with this subatrate, a clear ninhydrin-reactive zone of 3-aminopropanol appeared on chromatograms In addition to a faint ninhydrin-reactIve zone of B-alanine. Similarly, pantolc acid was readily detected by the ferric hydroxamate spray (118). The extract from the cells of the early logarithmic growth phase ( $35 \mathrm{hr}$ ) had the highest activity of pantothenyl alcohol cleavage ( 38 nmoles pantothenyl alcohol decomposed per mg per hr). The activitles of the cells grown for $45 \mathrm{hr}, 55$ hr, and $70 \mathrm{hr}$ were $73 \%, 58 \%$, and $27 \%$, respectively, of that of the cells grown for $35 \mathrm{hr}$. Pantothenic acid was not produced from pantothenyl alcohol, though it was cleaved to form B-alanine and

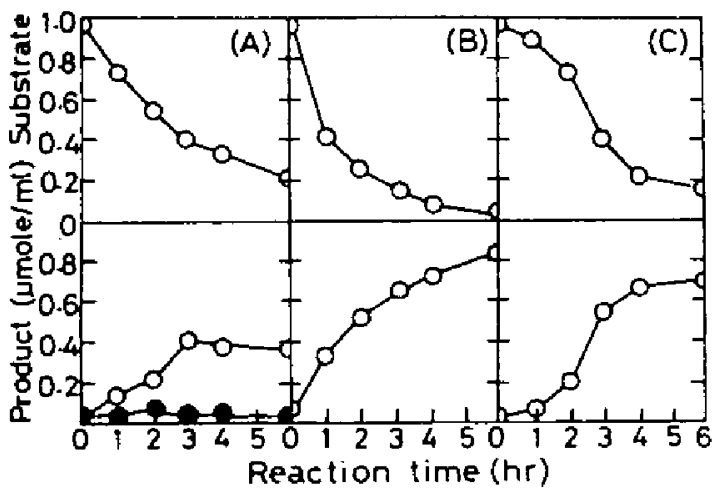

FIG. 2. Reactions Involved in the Degradation of Pantothenyl Alcohol by Strain 1041 .

(A) Degradation of pantothenyl alcohol: The reaction was carried out with $4.15 \mathrm{mg}$ of the crude enzyme. Other conditions are given in the text. Top, remaining pantothenyl alcohol; bottow, , pantothenic acid found; 0 , 3-aminopropanol found.

(B) Oxidation of 3-aminopropanol to b-alanine: The reaction was carried out with $4.15 \mathrm{mg}$ of the crude enzyme. other conditiona are given in the text. Top, remaln1ag 3-ablnopropanol; bottom, B-alanine found.

(C) Degradation of pantothen 1c acid: The reaction was carried out with $1.25 \mathrm{mg}$ of the crude enzyme. Other conditions are given in the text. Top, remaining pantothenic acid; bottom, B-alanine found.

The crude enzyme uas prepared frow the cells grown with pantothenyl alcohol for $40 \mathrm{hr}$ according to the method as described In the text. 
pantolc acid. 3-Amlnopropanol productIon from DL-pantothenyl alcohol was about 507 of that from D-pantothengl alcohol under condtions in which the cleavage of D-pantothenyl alcohol was complete. 3-Aminopropanol was oxidized to B-alanine; for the oxidation, netther NAD nor NADP wag required in either the dialyzed crude extract or the precipltates with ammonium sulfate (0.25-0.50 anturation). Part of the results obtalned from the experiments whth crude extract 18 shown in Fig. 2.

Metabolic products formed from pantotenyl alcohol by strain 1091. Straln 1091 accumulated pantothenic acid in the culture broth when grown in pantothenyl alcohol medium. The accumulation occurred after the f1rat $30 \mathrm{hr}$ and increased linearly with increasing the cell growth. The pantothentc acid formed diappeared rapldly during the atatlonary phase of growth. The maximium accumulation was $1.5 \mathrm{\mu moles} / \mathrm{ml}$, obtained from 44 hr culture. A ninhydrinreactive zone corresponding in position to 8-alanine, but not 3-aminopropanol, appeared on paper chromatograms, when the filtrate from $50 \mathrm{hr}$ culture was applied (Rf 0.65 and 0.53 , respectively, in solvents II and III). Th1s was active In enhancing the growth of Saccharomyces carlsbergensis ATCC 9080 .

The washed cells grown with pantothenyl alcohol for $40 \mathrm{hr}$ rapidly oxidized this substrate to pantothenic ac1d, whtch was 1solated as follows: A mixture, containing 0.8 mole of pantothenyl alcohol, 2 moles of potassium phosphate buffer, $\mathrm{pH} 7.0$, and $200 \mathrm{mg}$ (dry weight) of washed cells from the early logarithmlc growth phase ( $35 \mathrm{hr}$ ) in a total volume of $40 \mathrm{ml}$, was shaken for $15 \mathrm{hr}$ at $28^{\circ} \mathrm{C}$, bolled for $3 \mathrm{~min}$, and centrifuged. The supernatant was applied to a column of Dowex $1 \times 2$ (chloride form, $1.6 \times 20 \mathrm{~cm}$ ). After washing the column with water, pantothenic acid was eluted with $0.007 \mathrm{M} \mathrm{HCl}$. Appropr 1ate fractions were collected, neutralized with $\mathrm{Ca}(\mathrm{OH})_{2}$, and concentrated to drypess. The residue was dissolved in a omall volume of water and insoluble materials were centrifuged off. The supernatant was evaporated and the residue wog again dissolved In a small volume of water. These operations were repeated unt 11 a clear solution was obtained. This solution was evaporated to reduced volume, and the calcium salt of pantothenic acid was precipitated by adding ether (yield, $103 \mathrm{mg} ; \mathrm{PPC}, \mathrm{Rf}$ $0.85,0.74$, and 0.80 , respectively, in solventa I, II, and III; NMR at $60 \mathrm{MHz}$ ( $\delta \mathrm{ppm}): 0.90(3 \mathrm{H}, \mathrm{s}), 0.93(3 \mathrm{H}, \mathrm{s}), 2.42$ $(2 \mathrm{H}, t, J=7 \mathrm{~Hz}), 3.44(2 \mathrm{H}, t, J=7 \mathrm{~Hz}), 3.44$ $(2 \mathrm{H}, t), 3.98(1 \mathrm{H}, \mathrm{B}))$. In order to detect the formation of the aldehyde from pantotheny1 alcohol, the supernatant from a similar reaction mixture (40 ml) was passed through columns of Dowex $1 \times 2$ (OH, $18 \mathrm{ml}$ ) and then Dowex $50 \mathrm{~W} \times 8\left(\mathrm{H}^{+}\right.$, $20 \mathrm{ml})$. The passings and washings were concentrated to small volume, part of which was applled to TLC. A single blue zone was obtalned after treating with MBTH spray reagent (117) (Rf 0.83 in solvent I). No blue zone was detected when pantothenyl alcohol or pantothenate was applied. The MBTH derivative of the aldehyde was 1solated from the above concentrated solution as follows: The solution was combined with 5 ml of $0.1 \mathrm{M}$ of free MBTH solution, left for $3 \mathrm{hr}$, and concentrated to dryness. The residue was dissolved in a small volume of ethanol, insoluble materials were filtered off, and the filtrate was concentrated to dryness. The residue was dissolved in a small volume of water, and the azine crystallized was collected, and recrystallized twice from water (yleld, $28 \mathrm{mg}$; UV $\lambda \max$ in $10 \%$ ethanol, $314 \mathrm{~nm}$; PPC, Rf 0.38 in solvent I; TLC, Rf 0.73 in solvent III). Hydrolysis with $0.1 \mathrm{M} \mathrm{KOH}$ and with 0.1 $M$ HCl gave pantolc acid and pantolactone, respectively. Color yield of the MBTH derivative after oxidation with $\mathrm{FeCl}_{3}$ (Sawick1 reaction (117)) was observed $(\lambda \max : 618,668 \mathrm{~nm})$. Nelther pantothenyl alcohol plus MBTH, nor pantothenate plus MBTH ylelded the color. The same cells also cleaved pantothenate to yleld B-alanine and pantolc acid, which were Identified by use of similar methods to those described in the experiments with strain 1041, Cells of 
the ame organis grown elther with pantothenate or with glucose did not oxidize pantothenyl alcohol to pantothentc actd.

Dlalyzed crude extract from the cells grown with pantothenyl alcohol oxidized this substrate to pantothenic acid. But oxidation of 3-aminopropanol to Balanine was not catalyzed by the same extract under the conditlons enployed. The extract from the cells from the early logarithmic growth phase (35 hr) had the highest activity (65 noles pantothenyl alcohol oxidized per mg per hr) of the oxidation, and the activity gradually decreased with growth of the cells. The activities with the cells grown for $45 \mathrm{hr}, 55 \mathrm{hr}, 70 \mathrm{hr}$, and 100 hr were $64 \%, 42 \%, 30 \%$, and $13 \%$, respectively, of that with the cells grown for $35 \mathrm{hr}$. Nelther NAD nor NADP was required for the oxidation. When the

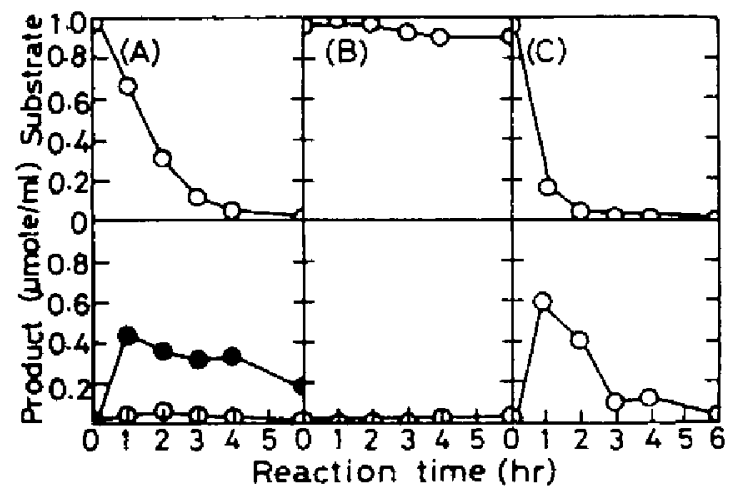

FIG. 3. Reactions Involued in the Degradation of Pantothenyl Alcohol by strain 1091.

(A) Oxidation of pantothenyl alcohol to pantothentc actd: The reaction was carried out wth $3.05 \mathrm{mg}$ of the crude enzyme. Other conditions are given in the text. Top, remaining pantothenyl alcohol; bottom, 9 , pantothenic actd found; 0,3 -aminopropanol found.

(B) Degradation of 3-aminopropanol: The reaction was carried out with $4.55 \mathrm{mg}$ of the crude enzyme. Other conditions are given in the text. Top, remaining 3-aminopropanol; bottom, B-alantne found.

(C) Degradation of pantothenic acid: The reaction was carried out with 1:05 mg of the crude enzyme. Other conditions are given in the text. Top, remaining pantothenic acid; botrom, B-alanine found.

The crude enzyme was prepared from the cells grown wth pantothenyl alcohol for $40 \mathrm{hr}$ according to the method as described in the text. aldehyde formation was asaayed by Sawlckl reaction (117), the Increase in absorbance at $570 \mathrm{~nm}$ with elapse of reaction time was observed. No Increase in absorbance was observed in either of the mixtures without pantothenyl alcohol or with pantothenate substituted for pantothenyl alcohol. The same extract contained a pantothenate-hydrolyzIng activity, and $B$-alanine formation from DL-pantothenate was about 50\% of that from D-pantothenate under cond 1tions giving complete cleavage of $\mathrm{D}$ pantothenate. Part of the regults obtalned from the experiments with crude extract is shown In Fig. 3 .

Conversion of pantothenyl alcohol to pantothenic acid by Bacillus roseus $A K U$ O208 and other strains

Activities of the accumilation of pantothenic acid from pantothenyl alcohol were surveyed in vartous microorgantsms; 138 stralns of bacterla, 205 strains of actinomycetes, 111 strains of molds, and 195 strains of yeasts. Among them Bacillus roseus AKU 0208 and Serratia plymuthicum AKU 0062 quantitatively converted it to pantothenic actd. Nocardia corallina IFO 3338, Streptomyces sp. AKU 2505, and Sarcina lutea IFO 3232 also showed high accumulation of pantothenic acid. However, strain 1091 and other pantothenyl alcohol ut1lizing stralns showed relatively lower accumulating activity under the conditions tested. In the following experiments, Bacillus roseus AKU 0208 was used.

Bacillus roseus AKU 0208 did not grow on pantothenyl alcohol medium. Ne1ther pantothenate nor 1ts hydrolyzed products was ut $111 z$ ed as carbon and nitrogen source. The whole broth and the washed cells rapidly converted pantothenyl alcohol to pantothentc acid. The converting activity in the cell was independent of pantothenyl alcohol supplement to the medium. No degradation of pantothenate was observed chough contact with the washed cells or cell extract for $6 \mathrm{hr}$ at $28^{\circ} \mathrm{C}$. Isolation of pantothenate was carried out as follows: A mixture, containing 3 moles of 
pantothenyl alcoho1, 1.26 moles of potasalum phosphate buffer, $\mathrm{pH} 7.0$, and $258 \mathrm{mg}$ (dry welght) of washed cells in a total volume of $60 \mathrm{ml}$, was shaken for $48 \mathrm{hr}$ at $28^{\circ} \mathrm{C}$. The supernatant from the reaction mixture was treated as described above to give the calclum salt (yleld, $466 \mathrm{mg}$; PPC, Rf $0.84,0.74$, and 0.79 , respectively, in solvents $I, I I$, and III; NMR at $60 \mathrm{MHz}(\delta \mathrm{ppm}), 0.90$ $(3 \mathrm{H}, 8), 0.93(3 \mathrm{H}, 8), 2.42(2 \mathrm{H}, \mathrm{t}, \mathrm{J}=7 \mathrm{~Hz})$, $3.44(2 \mathrm{H}, t, J=7 \mathrm{~Hz}), 3.44(2 \mathrm{H}, t), 3.98$ $(1 \mathrm{~B}, 8))$. For the 1solation of the aldehyde from pantothenyl alcohol, the same mixture, supplemented with 1.3 mooles of free MBTH, was shaken for 40 hr at $28^{\circ} \mathrm{C}$. After removing the cells by centrifugation, the supernatant was bolled for $1 \mathrm{mla}$, cooled, concentrated to small volume, and left at $5^{\circ} \mathrm{C}$ overnlght. The crystalline MBTH derivative of the aldehyde formed was collected and recrystallized twice from water (yield, 236 mg; UV $\lambda \max$ in $10 \%$ ethanol, $314 \mathrm{~nm}$; PPC, Rf 0.35 in solvent I; TLC, Rf 0.70 in solvent III; sulfur content, $8.76 \%$ (required, $8.80 \%)$ ).

\section{DISCUSSION}

Pantothenyl alcohol, an alcohol ana108 of pantothentc acid was reported to inhibit the growth of pantothenlc acidrequiring bacteria $(39,40)$, but several stralns isolated from soil were found to be capable of growing in the medium contalning it as a sole carbon and nitrogen source as described here. The results of the Invertigation on the degradative metabollsm of this compound in these strains demonstrated that there are two different inducible pathways.

The experiments with strain 1041 showed that 3-aminopropanol appeared In the early atage of the culture, and B-alantne in the stationary phase of growth without accumulation of pantothenlc acld. These, together with the observation that 3-aminopropanol plus pantoate, as well as pantothenyl alcohol, supported the growth of the induced culture suggest that pantothenyl alcohol is hydrolyzed to yleld 3-aminopropanol and pantolc acid as the firat step. Another result supporting this conclusion 18 that fapid hydrolyals of pantothenyl alcohol occurred during incubation with elther washed cell suspension or cell extract of the bacterium grown on pantothenyl alcohol, while no oxidation of this substrate to pantothentc actd was observed. When 3-antnopropanol was incubated with the washed cells or cell extract, only B-alanine was detected as a major product. Th1s observation suggests that the oxidation of 3-aminopropanol to $\beta$-alanine is nessesary for the further metabol1sm of 3-aminopropanol.

On the other hand, the degradative pathway operating in strain 1091 seems to be different from that operating in strain 1041. In the filtrate from cultures of strain 1091 grown in pantothenyl alcohol medium no 3-amtnopropanol appeared, while both pantcthenic acid and B-alanine were easily detected. Pantothenate and its hydrolytic products, i.e. B-alanine or B-alanine plus pantoate, as well as pantothenyl alcohol, supported the induced culture of the bacterlum. However, 3-aminopropanol or 3-aminopropanol plus pantoate, the hydrolytic products of pantothenyl alcohol, did not support the growth of the same organtsm. The cell extract and the washed cell suspension rapidly oxidized pantothenyl alcohol to pantothenlc acid. These observations strongly suggest that pantothenyl alcohol is first oxidized to pantothentc acid, which is then hydrolyzed to $B-a l a n i n e$ and pantoIc acid. Isolation of the aldehyde as the intermed late in the oxidation of pantothenyl alcohol to pantothenlc acid may give another plece of evidence for this conclusion.

The further metabolism of pantolc acid and B-alanine formed from pantothenyl alcohol In these organisms has not been investigated, since the metabollc fate of these compounds in other organisms is rather well known (123-130).

Pulsto and Nurmlkko (13I) and Mantsala and Nurmikko (132) reported that Pseudomonas fluorescens $\mathrm{P}-2$ contalns an Induclble amidase, pantothenate hydrolase, which hydrolyzes pantothenate to pantolc acid and B-alanine. The enzyme 
was Induced in the presence of pantothenate. But pantothenyl alcohol was Ineffective either $a s$ an inducer or as a substrate for the enzyme. Conversely, as shown in Table I, cell extract of

TABLE I. HYDROLASE ACTIVITIES AGAINST PANTOTHENY ALCOHOL AND PANTOTHENIC ACID IN STRAIN 1041

The cultivation was carried out as described in Fig. I except for carbon and nitrogen sources, and celle of logarithmic phase of grouth were harvested. The method for the preparation of the crude extract is described in the text. Activities are given as nmoles/mg/hr.

\begin{tabular}{|c|c|c|}
\hline \multirow{2}{*}{$\begin{array}{l}\text { Carbod and } \\
\text { nitrogen source }\end{array}$} & \multicolumn{2}{|c|}{$\begin{array}{c}\text { Hydrolase activity } \\
\text { ogainst }\end{array}$} \\
\hline & $\begin{array}{l}\text { pantothenyl } \\
\text { alcohol }\end{array}$ & $\begin{array}{c}\text { pantothenic } \\
\text { acid }\end{array}$ \\
\hline $\begin{array}{l}\text { Pantothenyl } \\
\text { alcohol (25 } \mathrm{M})\end{array}$ & 32 & 73 \\
\hline $\begin{array}{l}\text { Pantothenlc } \\
\text { acid (25 mil) }\end{array}$ & 0 & 97 \\
\hline $\begin{array}{r}\text { Glucose }(25 \mathrm{mM}) \\
+\mathrm{NH}_{4} \mathrm{Cl}(25 \mathrm{ml})\end{array}$ & 0 & 15 \\
\hline
\end{tabular}

straln 1041 grown with pantothenyl alcohol hydrolyzed not only this compound but also pantothenate, whlle that grown with pantothenate did not attack pantothenyl alcohol. Probably pantothenyl alcohol hydrolase and pantothenate hydrolase are different from each other. It 18 uncertain, however, whether the former can also attack pantothenate, since both enzymes were separated from each other in the present experiment.

Pantothengl alcohol was also oxidized to pantothenlc acld by Bacillus roseus ARU 0208. This organism did not grow on elther pantothenyl alcohol or pantothenate. The enzyme was not induced in the presence of pantotheny 1 alcohol. In the preliminary experiments, it observed that this enzyme acts on several primary alcohols including nethanol, ethanol, and so on. Details w11 appear eleswhere. 


\section{CONCLUSION}

Metabolic mechanigm of microbial conversion of pantothen1c acid to COA has been Investigated. Resting on the basis of the results, a new process for the production of COA and ite blosynthetic Intermed lates has been established. Presence of two different inductble routes for the degradation of pantothenyl alcohol has also been shown.

The activity of $\mathrm{COA}$ accumulation was searched in various microorgantsms. The result of screenting showed that several yeasts and bacteria accumulate CoA in high yields from pantothenic ac1d, cystelne, and AMP or ATP. Among them, Brevibacterium anmoniagenes IFO 12071 was found to be the most excellent CoA producer. The yleld was about $1 \mathrm{mg} / \mathrm{ml}$. Baker's yesst also accumulated $C O A$ $(200 \mu \mathrm{g} / \mathrm{ml})$ from pantothenic acid and cystelne under the condition coupled with ATP-generating system of the yeast.

Uolng drled cells of Brevibacterium anmoniagenes IFo 12071, the reaction conditions for CoA accumulat fon were estimated. The cells grown with acetic acid had the highest activity. Addition of surfactants to the reaction mixture brought a great acceleration of CoA accumulation. Under the suftable condition, the amount of COA accumslated reached $2 \mathrm{mg} / \mathrm{ml}$. COA was obtained with a high yleld from the reaction mixture. $3^{\prime}$-Dephospho-COA and $4^{\prime}$-Fhosphopantothenlc acid were also lsolated as byproducts. Further, including CoA it self, all the intermediates of CoA blosynthe818, though $4^{\prime}$-phosphopant ot henoylcysteine 18 an exception, were synthesized with high yields: When cysteine was omitted from the reaction mixture, only 4'-phosphopantothen 1c acid was accumulated. 4'-Phosphopantothen 1c acid coupled with cysteine in the presence of CTP, and ylelded $4^{\prime}$-phosphopantetheine. The direct and exclusive accumulation of 4'-phosphopant etheine, but not CoA, from pantothentc acid and cystelne wa also shown. Th1s was confirmed to be due to the broad spectfictty for the nucleotide in the phoephorylation of pantothenic ac1d and its restriction in the coupling of $4^{\prime}$-phosphopantethelne with ATP. 3'-Dephospho-CoA was obtained by treating the reaction mixture which had accumulated $C O A$ with 3'-nucleotldase of Bactlius subtlis IFO 3032. Cell extract of Brevibacterium ammoniagenes IFO 12071 contained all the enzymes necessary for the operation of Brown's pathway for the blosynthesis of CoA. Pantothenoylcysteine decarboxylase, an enzyme in Novelli's pathway, did not detected. These observations led to the conclusion that Brown's pathway operates in this bacterim. It was considered that Brown's pathway also operates in a wide varfety of microorgantems.

Pantothenate kinase, the enzyme catalyzing the first step in CoA blosynthesis, has been purified as a homogeneous protein from Brevibacterium ammoniagenes IFO 12071. The enzyme activity was inhibited by CoA and its biosynthetic intermediates. In many microorganisms tested, as well as Brevibacteri $\mathrm{um}$ anmoniagenes IFO 12071, CoA Inhtbited the phosphorylation of pantothenic acid, and resulted in a decrease of CoA production. These results led to the suggestion that a feedback inhibition of pantothenate kinase by CoA may be involved in regulating the intracellular CoA level as a general regulation mechantom. On the contrary, in all the CoA producing stralns, only little inhibition by COA was observed in other reactions involved in CoA blosynthesis, and CoA production from 4'-phosphopantothentc actd by Brevibacterium ammoniagenes IFO 12071 was not repressed even in the presence of $4 \mathrm{mM}$ of CoA. It was concluded that the higher accumulation of CoA from $4^{\prime}$-phosphopantothenic actd may be attributed to this less-sensitiveness of the enzymes.

The removal of permeability barriers of the cells by addition of surfactants was conflrmed by leakage of the enzymes of CoA biosynthesis from the cells, and it was shown that CoA syathesis occurred partly extracellularly. All the CoA producing atrains had considerably low degrading activitles against CoA and AMP. Th1s seemed to be one of the important featurea necessary for the 
production of COA.

On the basis of these results, a new process has been established for the production of CoA. Pantothentc actd, cystelne, and AMP when added to cultures of Brevibacterium ammoniagenes IFO 12071 gave CoA in a high yteld. The product was obtained by using Duolite $\mathrm{S}-30$, charcoal, and Dowex $1 \times 2$. The process has been shown to be adaptable for preparing large amounts of highly pure COA, because it is simple, rapld, and compact, and requires no spectal equipment. Simflarly, 4'-phosphopantothenlc ac1d and $4^{\prime}$-phosphopantetheine were readily obtalned in good ylelds.

Several microorganisms isolated from soil were found to grow in the medium contafning pantothenyl alcohol as a sole carbon and nitrogen source. The results of the investigation of the degradative metabolism of this compound demonstrated that there are two different inductble pathways. In the pathway operating in strain 1041, pantothenyl alcohol was first hydrolyzed to pantolc acid and 3-aminopropanol, which was then followed by oxidation to $\beta$ alanine. In strain 1091, pantothenyl alcohol was first oxidized to pantothen Ic acid which was then hydrolyzed to pantolc acid and B-alanine. 


\section{ACKNOWLEDGEMENT}

The euthor wlshes to thank Professor Kolch1 Ogata, Kyoto University, for his kind guldance and encouragement during the course of this work. The author is also grateful to Assoclate Professor Yoshlk1 Tan1, Kyoto Untversity, for his continuous guidance and advice in carrying out this work.

It is a great pleasure to acknowledge the valuable advices of Profeseor Tatsuo Yamamoto, Professor Tatsurokuro Toch1kura, Professor Hldeak1 Yamada, Assoclate Professor Kenj1 Soda, and Assoclate Professor Aktra Kimura, Kyoto Untversity.

The author is also Indebted to Dr. Masao Shimizu, Dalich1 Se1yaku Co., Ltd., Tokyo, for his kind gifts of some intermediates of CoA blosynthesis and strain Lactobacillus bulgaricus Bl, to Dr. Katsunobu Tanaka, Kyowa Hakko Kogyo Co., Ltd., Tokyo, for his kind gifts of some nucleotide derlvatives, to Dr. Elnosuke Ohmura, Takeda Chemical Industries Co., Ltd., Osaka, for his kind gift of synthetic CoA, to Dr. Makoto Yokoyama, Kojin Co., Ltd., Tokyo, for hls kind gift of ATP, to Assoctate Professor Norto Kurthara, Kyoto Untversity, for his kind interpretation of the NMR spectra, and to Mr. Akira Yaegash1, Boehringer Mannhelm Japan Co., Ltd., Tokyo, for his kind offer of facllitles for molecular weight determination of the pantothenate kinase.

Thanks are due to Mr. Kelf1ro M1yata, Mr. Shuhel Satauma, Mr. Katsuro Kubo, Mr. Hazlmu Morloka, and Mr. Ak1tsugu Kawato for thelr many helpful collaborations.

The author wlshes to express his sincere thanks to stuff members of tine Laboratory of Applied Microbiology, Department of Agricultural Chenlstry, stuff members of the Laboratory of Industrlal Microblology, Department of Food Science and Technology, stuff members of the Laboratory of Microbial Blochemistry. Institute for Chemical Research, and stuff members of the Laboratory of Applied Mlcroblology, Research Inst1tute for Food Sclence, Kyoto University. 


\section{REFERENCES}

1) R.J. W1111amB, W.A. Mosher and E. Rohrman, Biochem. J., 30, 2036 (1936).

2) D. Nachmansohn and A. L. Machado, J. Neurophysiol , 6, 397 (1943).

3) F. LIpmann and N.0. Kaplan, J. Biol. Chem., 162, 743 (1946).

4) F. Lipmann, J. Biol. Chem., 160, 173 (1945).

5) F. LIpmann, N.O. Kaplan, G.D. Nove111, L.C. Tuttle and B.M. Guirard, J. Biol. Chem., 167, 869 (1947).

6) F. Lynen and E. Relchert, Angew. Chem., 63, 47 (1951).

7) F. Lynen, E. Relchert and L. Rueff, Ann., 574, 1 (1951).

8) P.W. Majerus, A.W. Alberts and P.R. Vagelog, Proc. Nat1. Acad. Sci. $U$. s., 53, 410 (1965).

9) Excellent reviews of works on these coenzymes are avallable: L. Jaenicke and F. Lynen, "The enzymes," 2nd edition, Vol. III B, ed by P.D. Boyer, Academtc Press, Inc., New York, 1960, p. 3; F. Lynen, Fed. Proc., 20, 941 (1961); F. Lynen, Biochem. J., 102, 381 (1967); P.R. Vage10s, P.W. Majerus, A.W. Alberts, A. R. Larrabee and G.P. Allhaud, Fed. Proc., 25, 1485 (1966); D.J. Prescott and P.R. Vagelos, Advan. Enzymol., 36, 269 (1972); F. Lipmann, W. Gevers, H. Klelnkauf and R. RoskoskI, Jr., Advan. Enzymol, 35, 1 (1971); P.R. Vagelos, "The Enzymes," 3rd edition, Vol. VIIIA, ed by P.D. Boyer, Academic Press, Inc., New York, 1973, p. 155.

10) W.S. Plerpoint and D.E. Hughes, Abstr. Congr. Intern. Biochem., 2nd, Par18, 91 (1951); Biochem. J., 56, $130(1954)$.

11) G.M. Brown and E.E. Snell, J. Am. Chem. Soc., 75, 2782 (1953).

12) L. Levintow and G.D. Novelli, J. Biol. Chem., 207, 761 (1954).

13) M.B. Hoagland and G.D. Nove111, J. Biol. Chem., 207, 767 (1954).

14) G.M. Brown, J. Biol. Chem., 234, 370 (1959).

15) Y. Ab1ko, J. Biochem., 61, 290 (1967).

16) Y. Ab1ko, J. Biochem., 61, 300 (1967).

17) Y. Abiko, T. Suzuki and M. Shimizu, J. Biochem., 61, 309 (1967).
18) G.M. Brown, J. Biol. Chem., 234, 379 (1959).

19) G.M. Brown, J. Biol. Chem., 226, 651 (1957).

20) W.H. DeVries, W.M. Govier, J.S. Evans, J.D. Gregory, G.D. Novelli, M. Soodak and F. Lipmann, J. Am. Chem. Soc., 72, 4838 (1950).

21) J.D. Gregory, G.D. Hovelli and F. LIpmann, J. Am. Chem. Soc., 74, 854 (1952).

22) G.D. Nove111, N.O. Kaplan and F. Lipmann, Fed. Proc., 9, 209 (1950).

23) T.P. Wang, L. Shuster and N.0. Kaplan, J. Am. Chem. Soc., 74, 3204 (1952).

24) G.D. Novel11, Fed. Proc., 12,675 (1953).

25) H. Belnert, R.W. von Korff, D.E. Green, D.A. Buyske, R.E. Hand schumacher, H. HIggtns and F.M. Strong, J. Am. Chem. Soc., 74, 854 (1952); J. Biol. Chem., 200, 385 (1953).

26) E.R. Stadtman and A. Kornberg, J. Biol. Chem., 203, 47 (1953).

27) M.C. Reece, M.B. Donald and E.M. Crook, J. Biochem. Microbiol, Technol. Eng., 1, 217 (1959).

28) J.G. Moffatt and H.G. Khorana, J. Am. Chem. Soc., 81, 1265 (1959); 83, 663 (1961).

29) M. Kuno, M. Ktkuchi, Y. Nakao and S. Yamatodan1, Agr. Biol. Chem., 37, 313 (1973).

30) A.M. Mlchelson, Biochim. Biophys. Acta, 50, 605 (1961); 93, 71 (1964).

31) W. Gruber and F. Lynen, Ann., 659, 139 (1963).

32) M. Shimizu, O. Nagase, S. Okada, H. Hosokawa, H. Tagawa, Y. Ab1ko and T. Suzuki, Chem. Pharm. Bull., 13, 655 (1967).

33) K. Ogata and K. Kawagucht, J. Ferment. Technol., 50, 46 (1972), summarize the works relating to these flelds.

34) T. Tochikura, M. Kuwahara, S. Yag1, H. Okamoto, Y. Tomlnaga, T. Kano and K. Ogata, J. Ferment. Technol., 45, 511 (1967).

35) Excellent acounts of earlier works are avallable in "The Biochemistry of B Vitamins," by R.J. Williams, R.E. Eakin, E. Beerstecher and $W$. Shive, Retnhold, New York, 1950. 
Relatively recent works are summarlzed in "The Vitamins," 2nd ed1tiona, Vol. I (1967), Vol. II (1968), Vol. III (1971) and Vol. V (1972) ed. by W.H. Sebrell, Jr, and R.S. Harr1s, and VoI. VI (1967) and Vol. VII (1967) ed. by P. Gybrgy and W.N. Pearson, Academic Press, Inc., New York.

6) E.z. Burlet, z, Vitaminforsch., 14, 318 (1944).

7) 7. Schmidt, Acta Pharmacol. Toxi$\infty 1 ., 1,120(1945)$.

8) S.H. Rubin, J.M. Coopermen, M.E. Moore and J. Schelner, J. Nutrition, 35,499 (1948).

9) E.E. Snell and W. Sh1ve, J. Biol. Chem., 158, 551 (1945).

0) W. Drell and M.S. Dunn, Arch. Biochem. Biophys., 51, 391 (1954).

1) G.M. Brown and J.J. Reynolds, Ann. Rev. Blochem., 32, 419 (1963); Y. Abiko, "Shin-Bitamingaku," ed.by The Vitamin Soclety of Japan, Kyoto, 1969, p. 295; and M. ShImizu, Protein, Nucleic Acid and Enzyme, 16, 245 (1971) summarize the studies relatIng to CoA blosynthesis.

2) A.W.D. Avison, J. Chem. SoC., 1955, 732.

3) E.R. Stadtman, G.D. Novell1 and F. LIpmann, J. Biol, Chem., 191, 365 (1951).

4) H.U. Bergmeyer, G. Holz, H. Klotzsch and G. Lang, Biochem. Z., 338, 114 (1963).

5) H.R. Skegges and L.D. Wright, J. Biol. Chem., 156, 21 (1944).

6) O.D. Bird and R.Q. Thompson, "The Vitamins," 2nd editton, Vol. VII, ed. by P. Gybrgy and W.N. Pearson, Academ1c Press, Inc., New York, 1967, p. 225; L. Atkin, W.L. Williams, A. S. Schultz and C.N. Frey, Ind. Eng. Chem., Anal. Bd., 16, 67 (1944).

7) G.D. Novel11, "Methods of Biochemical Analysis," Vol. II, ed. by D. Glick, Intersclence Publishers, New York, 1955, p. 209.

8) C.H. Flake and Y. Subbarow, J. Biol. Chem., 65, 375 (1925).

9) G.L. Ellman, Arch. Biochem. Biophys., $82,70(1959)$.

0) C.S. Hanes and F.A. Isherwood, Nature, 164, 1107 (1949).
51) G. Toenntes and J.J. Kolb, Anal. Chem., 23, 823 (1951).

52) S.P. Sen and A.C. Leopold, Biochim. Bicphys. Acta, 18, 320 (1955).

53) A.R. Larrabee, E.G. McDantel, H.A. Bakerman and P.R. Vagelos, Proc. Nat. Acad. Sci. U. S., 54, 267 (1965).

54) S. Kurooka, K. Hosok1 and Y. Yoshimura, Chem. Pharm. Bul1., 15, 944 (1967).

55) E. Schwetzer, I. Lerch, L. KroeplinRueff and F. Lynen, Eur. J. Biachem., $15,472(1970)$.

56) K. Hosok1, S. Kurooka and Y. Yosh1mura, Radioisotopes, 21,502 (1972).

57) T. Nara, M. Misawa and S. Kinoshita, Agr. Biol. Chen., 31, 1351 (1967).

58) H. Tanaka, Z. Sato, K. Nakayama and s. KInoshita, Agr. Biol. Chem., 32, 721 (1968).

59) K. Nakayama, Z. Sato, H. Tanaka and S. Kinoshita, Agr. Biol. Chem., 32 , 1331 (1968).

60) A.W. Alberts and P.R. Vagelos, $J$. Biol. Chem., 241, 5201 (1966).

61) G.D. Novel11, "Methods of Biochemical Analysis," Vol. II, ed. by D. Glick, Intersclence Pub11shers, New York, 1955, p. 194.

62) N.O. Kaplan and F. Lipmann, J. Biol. Chem., 174, 37 (1948)

63) M.J. Somogy1, J. Biol. Chem., 195, 19 (1952).

64) J.H. Roe, J. Biol. Chem., 107, 15 (1934).

65) Y. Takahash1, Seikagaku, 26, 690 (1955).

66) T. Tochikura, Y. Mugtbayash1, H. Kawa1, K. Kawaguch1 and K. Ogata, Amino Acid and Nucleic Acid, 22, 144 (1970).

67) N. Kitafima, S. Watanabe and I. Takeda, J. Ferment. Technol., 48, $753(1970)$.

68) F.W. Putnam, Advan. Protein Chem., 4,79 (1948).

69) S.D. Sabato and N.O. Kaplan, J. Biol. Chem., 239, 438 (1964).

70) M. Relch and W.W. WaIno, J. Biol. Chem., 236, 3058 (1961).

71) A. Obayash1, Nippon Nogeikagaku Kaishi, 37, 265 (1963).

72) J. Takahash1, Y. Abegawa and K. Yamada, Nippon Nogeikagaku Kaishi, 34,1043 (1960). 
73) T. Kara, M. Misawa, T. Komuro and S. Klnoshlta, Agr. Biol. Chem., 33, 1198 (1969).

74) I. Sh110, S, Otauka and N. Katsuya, J. Bichern., 52, 108 (1962).

75) W.S. Plerpoint, D.E. Hughes, J. Baddfley and A.P. Mathias, Biochem. $J ., 61,368$ (1955).

76) K. Udagawa, S. Abe and S. Kinoshita, J. Ferment. Technol., 40, 614 (1962).

77) S. Watanabe, T. Osawa and S. Yamamoto, J. Ferment. Technol ., 46, 21 , 538 (1968).

78) Excellent revlews are avallable: $K$. Ogata, "Biochemical and Industrial Aspects of Fermentation," ed. by $k$. Sakaguch1, $T$. Uemura and $S$. Kinoah1ta, Kodansha, Ltd., Tokyo, 1971, p. 37; K. Ogata, "Kindai Kogyo-Kagaku," Vol. 23, ed. by R. Oda, S. Maklshtma, M. Imoto, W. Saka1 and $Y$. Iwakura, Asakura Publisher, Tokyo, 1969 , P. 185; K. Ogata and K. Kawaguch1, J. Ferment. Techno1., 50, 46 (1972).

79) T. Nara, M. Mlsawa and S. Kinoshita, Biotech. Bioeng., 10, 277 (1968).

80) K. Naka yama and H. Tanaka, Agr. Biol. Chem., 35, 518 (1971).

81) H. Tanaka and K. Nakayama, Agr. Biol. Chem., 36, 464 (1972).

82) T. Tochikura, H. Kawa1, S, Tobe, K. Kawaguch1, M. Osug 1 and K. Ogata, J. Ferment. Technol., 46, 957 (1968).

83) T. Tochikura, K. Kawagucht, T. Kano and K. Ogata, J. Ferment. Technol., 47,564 (I969).

84) T. Tochlkura, A. Kimura, H. Kawa1, T. Tachiki and T. Gotan, J. Ferment. Technol., 48, 763 (1970).

85) T. Toch1kura, A. K1mura, H. Kawa1 and T. Gotan, J. Ferment. Technol., 49,1005 (1971).

86) M. Misawa, T. Nara and S. Kinoshita, Agr. Biol. Chem., 33, 521 (1969).

87) R.J.L. Allen, Biochem. J., 34,858 (1940).

88) F. Lynen, Biochem. J., 102, 381 (1967).

89) F. Lipmann, W. Gevers, H. Klelakauf and R. Roskosk1, Jr, Advan. Enzymol., 35, 1 (1971).

90) J. Baddiley and E.M. Tha1n, J. Chem. Soc., 1951, 246; 1953, 1610.
91) T.E. King and F.M. Strong, $J$. Biol. Chem., 191, 515 (1951).

92) 0. Nagase, Chem. Pharm. Bull., 15, 684 (1967).

93) S. Okada, O. Nagage and M. Shtmizu, Chem. Pharm. Bul1., 15, 713 (1967).

94) T. Salto and I. Kunlyosh1, $J$. Vitaminol., 16, 64,70 (1970).

95) S. Igarash1 and A. Kaktnuma, Agr. Biol. Chem., 26, 218 (1962).

96) A. Kakinuma and S. Igarash1, Agr. Biol. Chem., 28, 131 (1964).

97) G.B. Ward, G.M. Brown and E.E. Sne11, J. Biol. Chem., 213, 869 (1955).

98) T. Karasawa, K. Yoshida, K. Furukawa and K. Hosok1, J. Biochem., 71,1065 (1972).

99) Y. Abiko, S. Ashida and M. Shimizu, Biochim. Biophys. Acta, 268, 364 (1972).

100) L. Ornstein and B.J. Davis, Ann. N. Y. Acad. Sci., 121, 321 (1964).

101) J. Kohn, "Chromatographic and Electrophoretic Techniques," Vol. II, William Heinemann Medical Books, Ltd., London, 1960, p. 56.

102) P. Andrews, Biochem. J., 96, 595 (1965) .

103) E. Racker, "Methods in Enzymology," Vol. I, ed. by S.P. Colowick and N.0, Kaplan, Academic Press, Inc., New York, 1955, p. 500.

104) B. Chance and A.C. Maehly, "Methods in Enzymology," Vo1. II, ed. by S. P. Colowlck and N.O. Kaplan, Academic Press, Inc., New York, 1955, p. 764 .

105) J.F. Taylor, "Methods in Enzymolo$g y, "$ Vol. I. ed. by S.P. Colowlck and N.O. Kaplan, Academic Press, Inc., New York, 1955, p. 310.

106) S. Omor1, Enzymologia, 4, 217 (1937).

107) 0.H. Lowry, N.J. Rosebrough, A.L. Farr and R.J. Randall, J. Biol. Chem., 193, 265 (1951).

108) M. We1ss, E. De Ritter, S.H. Rubin and L.D. Randall, Proc. Soc. Exptl. Biol. Med., 73, 292 (1950).

109) H. Lih, T.E. King, H. H1ggins, C. A. Baumann and F.M. Strong, J. Nutrition, 44, 361 (1951).

110) Y. Ab1ko, $M$. Tomikawa and $M$. Sh1mizu, J. Vitaminol., 15, 59 (1969). 
111) I. Ab1ko, M. Tom1kawa, Y. Hosokawa and M. Shimizu, Chem. Pharm. BulI., 17,200 (1969).

112) P.G. Stansly and M.E. Schloseer, J. Biol. Chem., 161, 513 (1945).

113) C.T. Goodhue and E.E. Snell, Biochemistry, 5, 393 (1966).

114) H. Michl, "Chromatographic Reviews", Vol. I, ed. by M. Lederer, Elsevier Publiahing Co., New York, 1959, p. 31 .

115) 0.D. Bird and L. McCready, Anal. Chem., 30, 2045 (1958).

116) Y. Sahash1, H. Takeda and N. Ohtsuk1, Vitamins, 32, 355 (1966).

117) E. Sawlck1, T.R. Hauser, T.W. Stanley and W. Elbert, Anal. Chem., 33,93 (1961).

118) V. Nurmikko, E. Salo, H. Hakola, K. Makinen and E.E. SneII, Biochemistry, 5, 399 (1966).

119) W. Schoninger, Mikrochim. Acta, $1956,869$.

120) P. Hugh and $E$. Lelfson, J. Bacteriol., 66, 24 (1953).

121) H. Kovacs, Nature, 178, 703 (1956).

122) E. O. KIng, M.K. Ward and D.E. Raney, J. Lab. Clin. Med., 54, 301 (1954).

123) W.I. Metzger, J. Bacteriol., 54, 135 (1947).

124) C.T. Goodhue and E.E. Snell, Biochemistry, 5, 403 (1966).

125) P.T. Magee and E.E. Snell, Biochemistry, 5, 409 (1966).

126) P. Manteala and V. Nurmikko, Suom. Remistilehti, B43, 414 (1970).

127) P. Mantsala, Suom. Kemistilehti, B43, 421 (1970).

128) V. Nurmikko, P. Mantsala and R. IsaksBon, Suom. Kemistilehti, B44, 323 (1971).

129) P. Mantbala, J. Gen. Miorobiol., 67,239 (1971).

130) P. Mantsala, M. Plrttikoski and V. Nurmikko, Acta Chem. Scand., 26, 395 (1972).

131) J. Pulsto and V. Nurmikko, Suom. Kenistilehti, B43, 44 (1970).

132) P. Mantbala and V. Nurmikko, suom. Kemistilehti, B43, 47 (1970). a) K. Ogata, S. Shimizu and Y. Tani, Agr. Biol. Chem,, 34, 1757 (1570).

b) K. Ogata, S. Shimizu and Y. Tan1, Agr. Biol. Chem., 36, 84 (1972).

c) K. Ogata, Y. Tan1, S. Sh1mizu and K. Uno, Agr. Biol. Chem., 36, 93 (1972).

d) S. Shimizu, Y. Tan 1 and K. Ogata, Agr. Biol. Chem., 36, 370 (1972).

e) S. Shimizu, K. Miyata, Y. Tan $i$ and K. Ogata, Biochim. Biophys. Acta, $279,583(1972)$.

f) S. Shimizu, K. Miyata, Y. Tant and K. Ogata, Agr. Biol. Chem., 37,607 (1973).

g) S. Shimlzu, K. Mtyata, Y. Tani and K. Ogata, Agr. Biol. Chem., 37,615 (1973).

h) S. Shimizu, S. Satsuma, K. Kubo, Y. Tan1 and K. Ogata, Agr. Biol. Chem., 37,857 (1973).

1) S. Shimizu, K. Kubo, S. Satauma, Y. Tan 1 and K. Ogata, J. Ferment. Technol., 52,114 (1974).

j) S. Shimizu, K. Kubo, Y. Tan 1 and $K$. Ogata, Agr. Biol. Chem., 37, 2863 (1973).

k) S. Shimizu, K. Kubo, H. Morloka, Y. Tan 1 and K. Ogata, Agr. Biol. Chem. 38,1015 (1974).

1) S. Shimizu, Y, Tan 1 and K. Ogata, Agr. Biol. Chem., submitted. 